Juliane Cristina Borba

\title{
Estudo bioanalítico e metabolômico da Psidium guajava submetida à adubação diferenciada
}

Dissertação apresentada ao Instituto de Química de São Carlos da Universidade de São Paulo como parte dos requisitos para a obtenção do título de Mestre em Ciências.

Área de concentração: Química Analítica e Inorgânica

Orientador: Professor Dr. Emanuel Carrilho

São Carlos

2012 
Aos meus pais,

\section{Margarete Borba e}

\section{Paulo Borba (em memória)}

Que me ensinaram a levantar e seguir em frente a cada dificuldade, me ensinaram que nunca é hora de desistir, e o mais importante de tudo, me ensinaram que mesmo longe dos olhos vão sempre estar perto do meu coração.

Aos meus irmãos,

\section{Paulo Roberto Borba e}

\section{Rubiane Aline Borba}

Meus irmãos por destino e amigos por opção, meus companheiros para toda a vida.

A minha sobrinha,

\section{Eduarda Monteiro Borba}

Que um dia poderá ver nessa lembrança o quanto sempre foi amada e o quanto foi importante para minha conquista. 


\section{AGRADECIMENTOS}

A Deus,

Aos meus pais, por todo apoio desde o sempre, pela paciência, amor e dedicação, que me permitiu chegar até aqui. A minha mãe por ser essa guerreira, protetora e ter me mostrado que é sempre preciso continuar. Ao meu pai, por mesmo longe estar sempre cuidando de mim e por ter me deixado em boas mãos, nossa família.

A minha irmã que me aguentou, me aguenta e me aguentará. Por me escutar falando de goiaba e de eletroforese capilar milhões de vezes. Por não me deixar desanimar, por me deixar o jantar pronto em todas as vezes que fiquei até tarde no laboratório e por muito mais coisas que nem posso enumerar.

Ao meu irmão e minha cunhada por no meu primeiro ano de mestrado terem me dado o maior estímulo, minha sobrinha, quem fez e faz meus finais de semana mais serenos, mais divertidos e principalmente, me recarrega para continuar.

A Ceres Borelli e Cybele Martins por toda a ajuda, pelas palavras de estimulo e pelas correções de português.

Ao professor Dr. Emanuel Carrilho, pela confiança em me receber no seu grupo, pela orientação, disponibilidade e paciência. 
A Karina Fraige, também pela paciência, pela ajuda, pelas conversas, ideias e brigas com o CE e por ter me dado o prazer de ganhar uma amiga.

Ao grupo BioMicS, pela ajuda, apoio, por me ouvirem, mais uma vez pela paciência, festinhas durante a semana que sempre levantaram os ânimos e me fizeram engordar, conversas e fofocas no lab. 7 e principalmente para o clube da Luluzinha que me fizeram sentir parte dessa família e se tornaram tão importante para mim.

Ao Pesquisador Daniel Angelucci de Amorim e ao Professor Dr. William Natale, da UNIVERSIDADE ESTAdUAL PAULISTA “JÚLIO DE MESQUITA FILHO” FACULDADE DE CIÊNCIAS AGRÁRIAS E VETERINÁRIA CÂMPUS JABOTICABAL, pela grande disponibilidade em ceder as amostras de goiaba e grande ajuda.

Ao INCtBio e a CAPES pelo apoio financeiro.

A todos aqueles que de uma forma ou de outra colaboraram com mais essa conquista. 
“Hoje entendo bem meu pai. Um homem precisa viajar. Por sua conta, não por meio de histórias, imagens, livros ou TV. Precisa viajar por si, com seus olhos e pés, para entender o que é seu. Para um dia plantar as suas próprias árvores e dar-Ihes valor. Conhecer o frio para desfrutar do calor. E o oposto. Sentir a distância e o desabrigo para estar bem sob o próprio teto. Um homem precisa viajar para lugares que não conhece para quebrar essa arrogância que nos faz ver o mundo como o imaginamos, e não simplesmente como é ou pode ser. Que nos faz professores e doutores do que não vimos, quando deveríamos ser alunos, e simplesmente ir ver". 


\section{RESUMO}

A goiaba é o fruto da goiabeira, originária da América Tropical, e pertence à família Myrtaceae, gênero Psidium e espécie Psidium guajava L. Ela pode ser encontrada em todas as regiões do Brasil, sendo o Estado de São Paulo um dos principais produtores. Mundialmente o Brasil está entre os principais produtores, no entanto, sua participação no mercado internacional da fruta in natura ainda é inexpressiva. A goiaba é apreciada tanto fresca como processada industrialmente na forma de doces, compotas, geléias e sucos. Ela possui propriedades nutracêuticas devido a seus nutrientes, vitaminas e substâncias bioativas, como a vitamina C, além de possuir altos teores de carotenóides. Devido a crescente importância econômica da fruta, além do interesse em alimentos mais saudáveis, é importante conhecer os metabólitos presentes na goiaba, no intuito de promover seu consumo. Diferentes fatores podem influenciar na composição e qualidade da fruta, como tipo de solo, poda, fornecimento de água e adubação. Considerando a adubação, há poucos estudos no Brasil em relação aos níveis corretos para aumentar a produção sem afetar a qualidade do fruto. $\mathrm{O}$ objetivo desse trabalho foi avaliar características físicas e químicas da goiaba Paluma cultivada na região de Jaboticabal, submetida a diferentes doses de adubação nitrogenada, durante quatro diferentes estádios de desenvolvimento do fruto. As análises dos carboidratos e vitaminas foram realizadas por eletroforese capilar e dos carotenóides por cromatografia líquida em fase reversa, e os resultados avaliados por análise de componentes principais (PCA). Foi observada uma variação nos níveis de todos os metabólitos analisados em relação à quantidade de nitrogênio administrado, sendo que a concentração de glicose, frutose e sacarose na goiaba madura foram maiores nas amostras fertilizadas com duas doses de nitrogênio, assim como para o ácido ascórbico total e betacaroteno. Em geral, o nível de sacarose em relação à glicose e frutose diminuiu durante o desenvolvimento da fruta, enquanto o nível de betacaroteno aumentou para as amostras adubadas com uma e duas doses de nitrogênio. As análises de PCA permitiram diferenciar os estádios de desenvolvimento dos frutos, no entanto as diferentes doses de adubação não proporcionaram a formação de grupos distintos, indicando que cada variável foi influenciada diferentemente por cada nível de adubação.

Palavras chave: goiaba, metabólitos, maturação, eletroforese capilar. 


\section{ABSTRACT}

The guava is the fruit from a guava tree, native from tropical America, belonging to the family of Myrtaceae, Psidium genus and Psidium guajava L. species. It can be found in all regions of Brazil, and the São Paulo State is one of the main producers. Globally, Brazil is among the main producers; however, its international market of the fresh fruit is still unimpressive. Guava is appreciated as both fresh and processed industrially as candies, jams, jellies, and juices. It has nutraceutical properties due to its nutrients, vitamins, and bioactive substances, such as vitamin $\mathrm{C}$, besides having high levels of carotenoids. Due to the growing economic importance of this fruit and the interest in healthier foods, it is important to study the metabolites present in guava to promote their consumption. There are different factors that can influence the composition and quality of the fruit before harvesting, such as soil type, pruning, water supply, and fertilization. In relation to the fertilization, there are only a few studies in Brazil regarding the correct levels to increase the production of guava, maintaining the quality of the fruit. The aim of this study was to evaluate physical and chemical characteristics of guava Paluma from Jaboticabal region, under different nitrogen fertilizer levels during four stages of fruit development. The analyses of carbohydrates and vitamins were performed by capillary electrophoresis and the analyses of carotenoids were done by high performance liquid chromatography, and the results were evaluated by principal component analysis (PCA). It was observed a variation in levels of all metabolites in relation to nitrogen administered, being the concentration of glucose, fructose, and sucrose on the ripe guava higher on the samples fertilized with two doses of nitrogen, as well as for the total ascorbic acid and beta-carotene. In general, the levels o sucrose with respect to glucose and fructose decreased during the fruit development, whereas beta-corotene levels increased for the samples fertilized with one and two doses. The PCA data allowed differentiating among the stages of development, but the doses of nitrogen did not provide separate clusters, indicating that each variable was differently influenced by each fertilizer level.

Keywords: guava, metabolites, ripening, capillary electrophoresis. 


\section{LISTA DE FIGURAS}

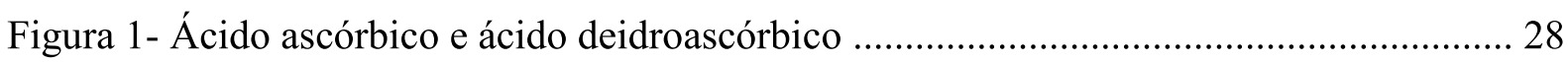

Figura 2- Estruturas dos principais carotenoides presentes na goiaba: (A) $\beta$-caroteno; (B)

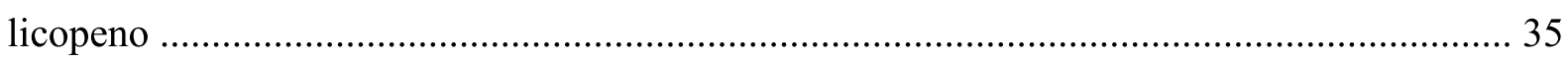

Figura 3 - Goiabas coletadas em 4 diferentes estádios de desenvolvimento ........................ 40

Figura 4 - Perfil diâmetro transversal e longitudinal em relação ao desenvolvimento para todas as diferentes adubações: (a) transversal; (b) longitudinal 52

Figura 5 - Relação DL/DT em relação ao desenvolvimento para todas as diferentes adubações

Figura 6 - Variação do pH em relação o desenvolvimento para as diferentes adubações ...... 55 Figura 7 - Variação do IPT em relação ao desenvolvimento para todas as diferentes adubações 56

Figura 8 - Variação do ATT em relação ao desenvolvimento para todas as adubações 57

Figura 9 - Variação do ${ }^{\circ}$ Brix em relação ao desenvolvimento para todas as diferentes adubações

Figura 10 - Relação SST/ATT em relação ao desenvolvimento para todas as diferentes adubações 61

Figura 11 - Curva de calibração analítica para glicose 62

Figura 12 - Variação dos açúcares redutores totais com o desenvolvimento para todas as variações de adubação 63

Figura 13 - Eletroferograma referente à amostra $\mathrm{N}_{2}$ e padrão 66

Figura 14 - Variação dos açúcares com o desenvolvimento nas quatro diferentes adubações: a) $\mathrm{N}_{0}$; b) $\mathrm{N}_{1}$; c) $\mathrm{N}_{2}$; d) $\mathrm{N}_{3}$ $68 / 69$

Figura 15 - Pectina extraída da goiaba triturada em solução etanólica 71

Figura 16 - Eletroferograma referente ao produto de hidrólise da amostra $\mathrm{N}_{2}$ e mistura de padrão 73

Figura 17 - Variação da razão molar dos açúcares neutros da pectina com o desenvolvimento nas quatro diferentes adubações: a) $\mathrm{N}_{0}$; b) $\mathrm{N}_{1}$; c) $\mathrm{N}_{2}$; d) $\mathrm{N}_{3}$ $77 / 78 / 79$

Figura 18 - Eletroferograma referente a amostra $\mathrm{N}_{2}$ e padrão 83

Figura 19 - Variação do ácido ascórbico (a) e ácido ascórbico total (b) em relação ao estádio de desenvolvimento nas quatro diferentes adubações $85 / 86$ 
Figura 20 - Variação do ácido desidroascórbico em relação ao estádio de desenvolvimento nas quatro diferentes adubações

Figura 21 - Variação do ácido ascórbico (a) e ácido ascórbico total (b) em relação ao estádio de desenvolvimento nas quatro diferentes adubações

Figura 22 - Variação do ácido desidroascórbico em relação ao estádio de desenvolvimento nas quatro diferentes adubações

Figura 23 - Comparação do teor de ácido ascórbico entre a primeira (2010) e segunda (2012)

etapa de coletas, para as coletas 3 (a) e 4 (b)

Figura 24 - Comparação do teor de ácido ascórbico total entre a primeira (2010) e segunda (2012) etapas de coletas, para as coletas 3 (a) e 4 (b)

Figura 25 - Comparação do teor de ácido desidroascórbico entre a primeira (2010) e segunda (2012) etapa de coletas, para as coletas 3 (a) e 4 (b) .......................................................... 94

Figura 26 - Cromatograma referente padrão de betacaroteno e a uma amostra ..................... 97

Figura 27 - Variação do betacaroteno em relação ao estádio de desenvolvimento nas quatro diferentes adubações 98

Figura 28 - Comparação do teor de betacaroteno em amostras de goiaba nas diferentes adubação, em relação à época da coleta, coleta 2010 (inverno) e coleta 2012 (verão) 99

Figura 29 - Variação do licopeno em relação ao estádio de desenvolvimento nas quatro diferentes adubações 100

Figura 30 - Gráficos de scores para coleta $\left(\mathrm{C}_{1}-1, \mathrm{C}_{2}-2, \mathrm{C}_{3}-3\right.$ e $\left.\mathrm{C}_{4}-4\right)$ (a) e adubação $\left(\mathrm{N}_{0}-1\right.$; $\mathrm{N}_{1}-2 ; \mathrm{N}_{2}-3 ; \mathrm{N}_{3}-4$ ) (b) e gráfico de loadings (c) $101 / 102$

Figura 31 - Gráficos de scores para coleta (a) e adubação $\left(\mathrm{N}_{0}-1 ; \mathrm{N}_{1}-2 ; \mathrm{N}_{2}-3 ; \mathrm{N}_{3}-4\right)$ (b) e gráfico de loadings $(\mathrm{c})$, para análises básicas $103 / 104$ 


\section{LISTA DE TABELAS}

Tabela 1- Principais estados brasileiros produtores de goiaba

Tabela 2- Características físicas, físico-químicas e químicas de frutos da cultivar Paluma produzida na região do submédio São Francisco ................................................................... 19

Tabela 3- Valores de pKa de alguns carboidratos neutros ................................................. 23

Tabela 4 - Características físicas (média \pm desvio padrão) de diâmetro transversal (DT), diâmetro longitudinal (DL) e relação DL/DT durante o desenvolvimento dos frutos nas diferentes adubações

Tabela 5 - ${ }^{\circ}$ Brix (média \pm desvio padrão) durante o desenvolvimento nas diferentes adubações

Tabela 6 - Açúcares redutores totais (média \pm desvio padrão) durante o desenvolvimento nas diferentes adubações

Tabela 7 - Equações de regressão linear, coeficientes de correlação e faixa de concentração estudada para cada um dos açúcares estudados

Tabela 8 - Precisão do método para análises intra-dia e entre-dias

Tabela 9 - Concentração dos açúcares solúveis presentes na goiaba (média \pm desvio padrão)

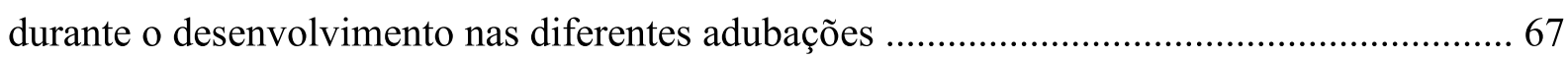

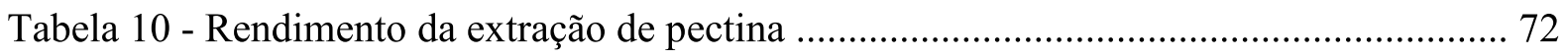

Tabela 11 - Equações de regressão linear, coeficientes de correlação, limite de detecção (LD), limite de quantificação (LQ) e faixa de concentração estudada para cada um dos açúcares

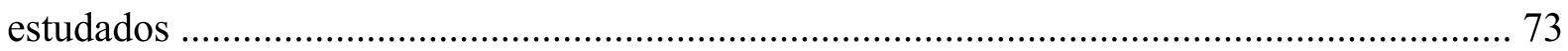

Tabela 12 - Precisão do método para análises intra-dia e entre-dias 74

Tabela 13 - Razão molar entre os principais açúcares neutros encontrados para uma amostra aleatória de pectina, hidrolisada em 3 diferentes tempos

Tabela 14 - Proporção dos principais açúcares neutros presentes na pectina (média \pm desvio padrão) durante o desenvolvimento nas diferentes adubações

Tabela 15 - Equação de regressão linear, coeficiente de correlação, limite de detecção (LD), limite de quantificação (LQ) e faixa de concentração estudada para o ácido ascórbico

Tabela 16 - Precisão do método para análises intra-dia e entre-dias 82

Tabela 17 - Recuperação do método de eletroforese capilar .83 
Tabela 18 - Concentração do ácido ascórbico (AA), ácido ascórbico total (AA Total) e ácido desidroascórbico (DIA), (média \pm desvio padrão) durante o desenvolvimento nas diferentes adubações 84

Tabela 19 - Concentração do ácido ascórbico (AA), ácido ascórbico total (AA Total) e ácido desidroascórbico (DIA), segunda etapa de coletas, (média \pm desvio padrão) durante o desenvolvimento nas diferentes adubações 89

Tabela 20 - Equação de regressão linear, coeficiente de correlação, limite de detecção (LD), limite de quantificação (LQ) e faixa de concentração estudada para o betacaroteno . 96

Tabela 21 - Precisão do método para análises intra-dia e entre-dias de carotenoides 96

Tabela 22 - Concentração do betacaroteno (média \pm desvio padrão) durante o desenvolvimento nas diferentes adubações 97 


\section{Sumário}

1 INTRODUÇÃ

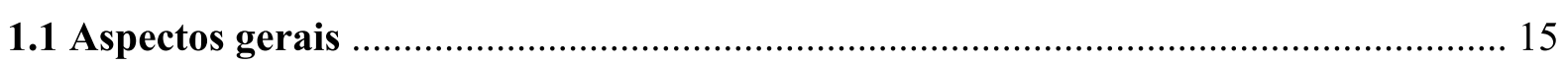

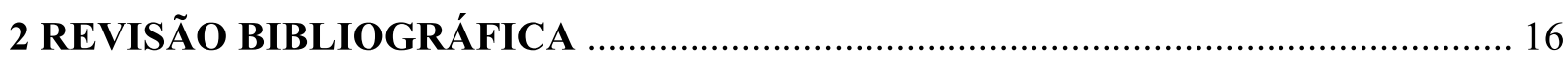

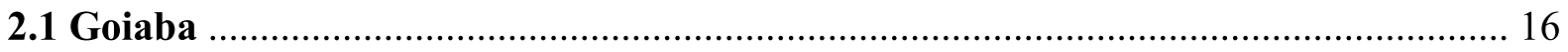

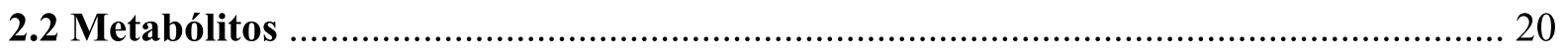

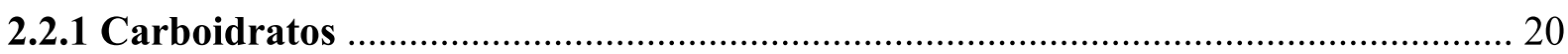

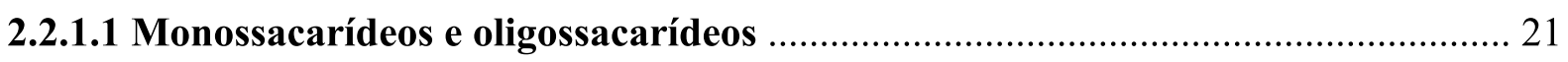

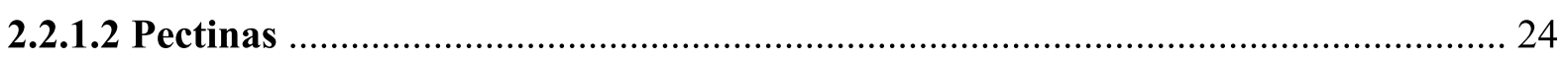

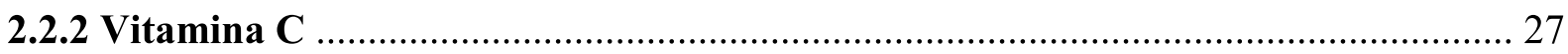

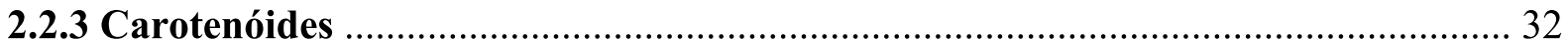

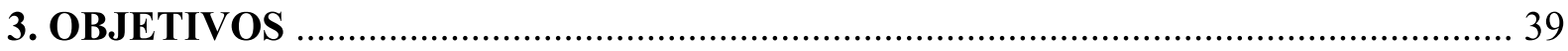

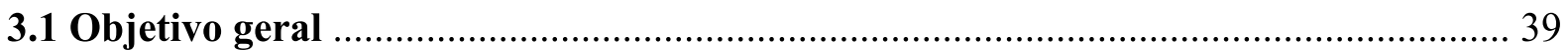

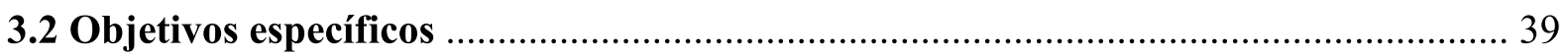

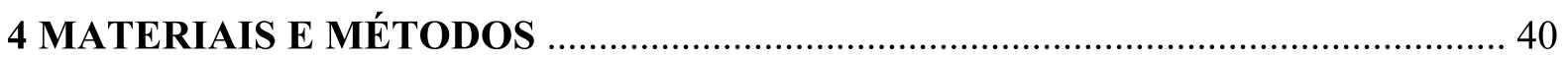

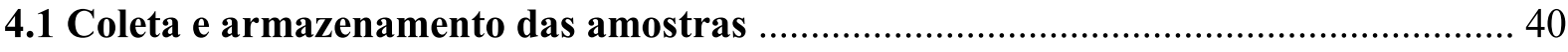

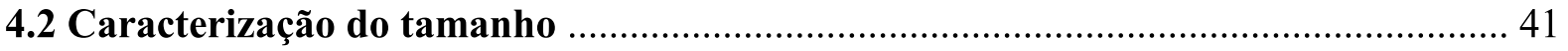

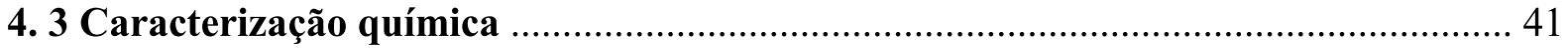

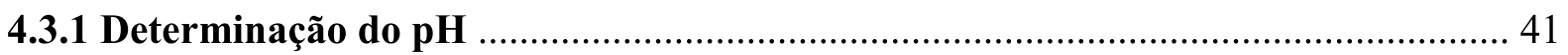

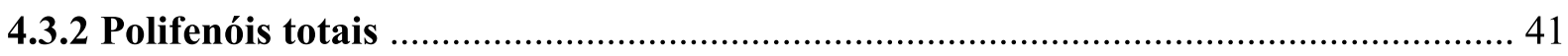

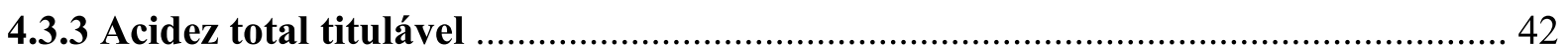

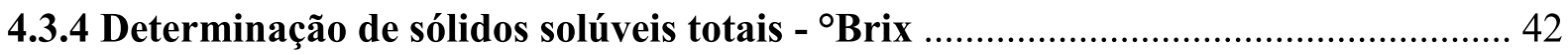

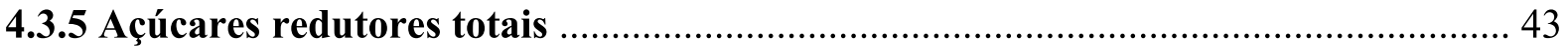

4.3.6 Principais mono e dissacarídeos solúveis na goiaba ............................................ 43

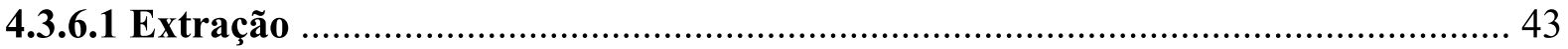

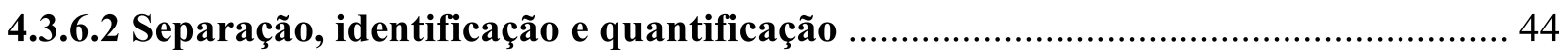

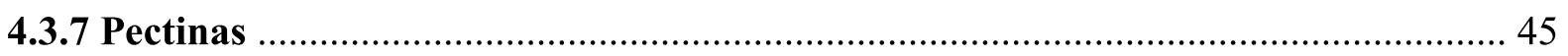

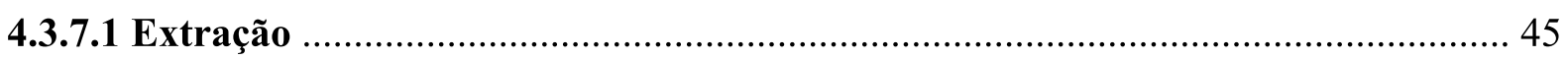

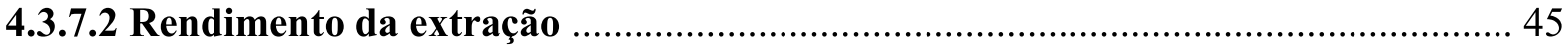

4.3.7.3 Caracterização dos açúcares neutros presentes na pectina …............................ 45 
4.3.7.3.1 Hidrólise 45

4.3.7.3.2 Separação, identificação e quantificação 46

4.3.8 Determinação de ácido ascórbico, deidroascórbico e ácido ascórbico total 46

4.3.8.1 Extração 46

4.3.8.2 Separação, identificação e quantificação 47

4.3.9 Carotenoides majoritários 47

4.3.9.1 Extração dos carotenoides 47

4.3.9.2 Separação e identificação dos carotenóides por cromatografia líquida de alta eficiência (HPLC) 48

4.4 Análise Estatística e Quimiométrica dos dados 49

5 RESULTADOS E DISCUSSÃO 50

5.1 Coleta e armazenamento das amostras 50

5.2 Caracterização do tamanho 50

5.3 Caracterização Química 54

5.3.1 Determinação do pH 54

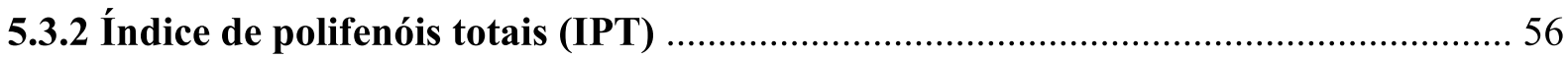

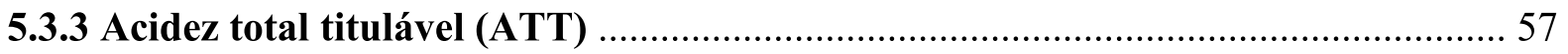

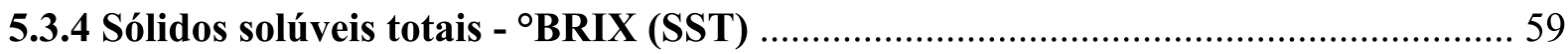

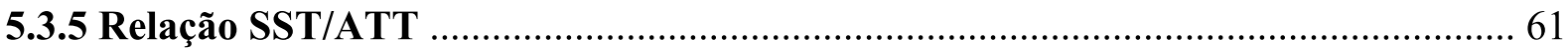

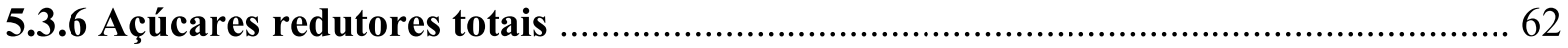

5.3.7 Principais mono e dissacarídeos livres na goiaba (Sacarose, Glicose e Frutose) ... 64

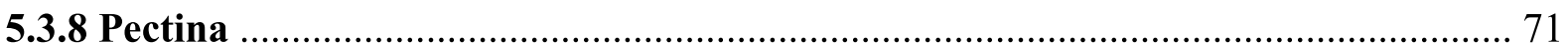

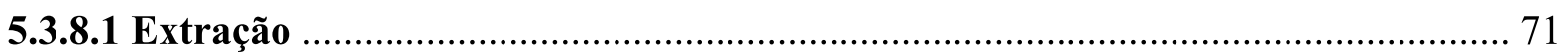

5.3.8.2 Caracterização dos açúcares neutros presentes na pectina ….............................. 72

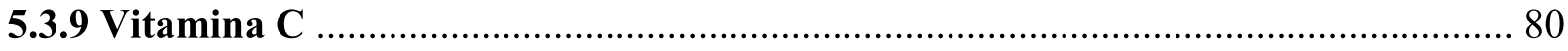

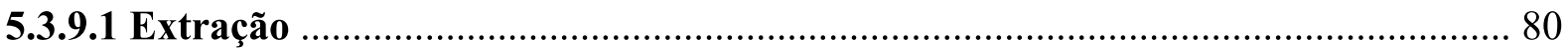

5.3.9.2 Determinação de ácido ascórbico total e ácido deidroascórbico …...................... 81

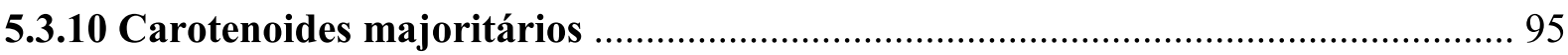

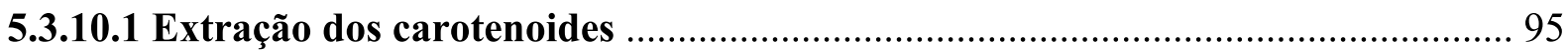

5.3.10.2 Separação e identificação dos carotenoides por cromatografia líquida de alta

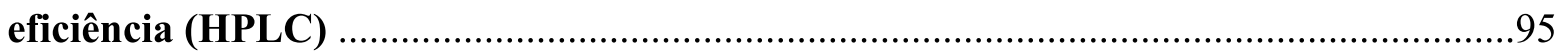

5.4 Análise de Componentes Principais (PCA) .............................................................. 101 
6 CONCLUSÃO 106

7 REFERÊNCIAS BIBLIOGRÁFICAS 


\section{INTRODUÇÃO}

\subsection{Aspectos gerais}

Segundo o Instituto Brasileiro de Geografia e Estatística (IBGE, 2011), o estado de São Paulo está entre os principais produtores de goiaba do país, ocupando em 2010 o primeiro lugar tanto em relação a quantidade e valor de produção, quanto em relação ao rendimento. Os principais produtores brasileiros de goiaba e sua produção, durante o ano de 2010, são apresentados na Tabela 1.

Tabela 1- Principais estados brasileiros produtores de goiaba.

\begin{tabular}{c|c|c|c|c}
\hline ESTADOS & $\begin{array}{c}\text { Produção } \\
\text { (ton.) }\end{array}$ & $\begin{array}{c}\text { Produção } \\
\text { (mil reais) }\end{array}$ & $\begin{array}{c}\text { Área plantada } \\
\text { (hectare) }\end{array}$ & $\begin{array}{c}\text { Rendimento médio } \\
\text { (kg/hectare) }\end{array}$ \\
\hline São Paulo & 98.272 & 65.925 & 3.610 & 27.373 \\
Pernambuco & 90.496 & 58.278 & 3.641 & 26.710 \\
Minas Gerais & 12.574 & 15.096 & 913 & 13.772 \\
Bahia & 14.217 & 9.914 & 828 & 17.170 \\
Goiás & 10.277 & 3.739 & 242 & 42.466 \\
\hline
\end{tabular}

Fonte: IBGE (2011)

No estado de São Paulo, a produção localiza-se principalmente nos municípios de Vista Alegre do Alto, Monte Alto e Taquaritinga, região de Jaboticabal, onde se concentram as indústrias processadoras da fruta.

A importância econômica da cultura da goiaba, tanto para mercado interno como para exportação, ocorre em virtude das várias formas de aproveitamento do fruto para produção de polpa na indústria de néctar, de sucos, de refrigerantes, de compotas, de biscoitos e de muitos outros produtos, além de ser amplamente consumida como fruta fresca. $\mathrm{O}$ valor da goiaba está diretamente relacionado com a cor da polpa (branca ou vermelha), com o tamanho e com a qualidade.

$\mathrm{Na}$ produção industrial, destacam-se as goiabas de polpa vermelha que possuem altos teores de sólidos solúveis e acidez elevada, alto teor de ácido ascórbico e pequena quantidade de sementes (DURIGAN; MATTIUZ; MORGADO, 2009). No entanto, para sua aceitação no 
mercado interno e externo, é necessário que o produto se enquadre nos padrões internacionais de qualidade, sendo fundamental possuir boas características como sabor, aroma e consistência. Por isso, o conhecimento das propriedades químicas e físicas da goiaba é um fator altamente relevante uma vez que elas são utilizadas como referência para a sua aceitabilidade e colaboram para o aumento do consumo da fruta.

Dentre as características químicas mais importantes, podem-se destacar $\mathrm{pH}$, acidez titulável e teor de sólidos solúveis ( ${ }^{\circ}$ Brix); dentre as características físicas, podem-se destacar peso do fruto, diâmetro longitudinal e diâmetro transversal (GOUVEIA, et al.,2004).

\section{REVISÃO BIBLIOGRÁFICA}

\subsection{Goiaba}

A goiaba é uma das frutas mais completas e equilibradas com relação ao valor nutritivo. A goiaba vermelha contém, em média, 85\% de umidade, $227 \mathrm{~kJ}$ (54 kcal) de

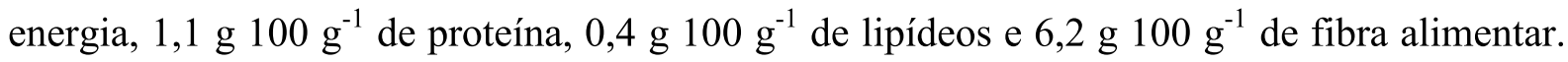
É uma fruta rica em açúcares e antioxidantes, como a vitamina $\mathrm{C}$, possuindo de três a quatro vezes mais que a laranja (DURIGAN; MATTIUZ; MORGADO, 2009). Destacam-se também os carotenoides, como licopeno e $\beta$-caroteno, responsáveis pela coloração vermelha da polpa, e as pectinas, muito interessantes para a indústria alimentícia devido às suas propriedades geleificantes (LEITE et al., 2006).

Devido a essas características, a goiaba é considerada uma fonte de micronutrientes e de substâncias bioativas importantes; consequentemente, um alimento funcional. Alimento funcional é definido como todo alimento que, além das funções nutritivas básicas, quando consumido como parte da dieta usual, produz efeitos metabólicos e/ou fisiológicos e/ou efeitos benéficos à saúde, sendo seguro para consumo sem supervisão médica (MORAES; COLLA, 2006). O consumo de alimentos funcionais tem crescido muito nos últimos anos, devido à grande preocupação com a saúde e a procura por uma alimentação saudável, tornando o mercado ainda mais atrativo.

É muito importante o conhecimento das propriedades químicas e físicas da goiaba uma vez que esses parâmetros são utilizados como referência para a sua aceitabilidade tanto no comércio da fruta in natura, quanto para indústria, sendo que, para processamento industrial, as goiabas devem ter teores de sólidos solúveis e de acidez elevados, alto teor de ácido 
ascórbico e pequena quantidade de sementes, apresentando-se maduras, mas firmes (MARTIN; KATO, 1988). Estas propriedades também são importantes para determinação do estádio de maturação do fruto (AZZOLINI, 2002).

As características químicas e físicas variam de acordo com o ciclo vital da fruta que, após a germinação, passa por diferentes fases durante o seu desenvolvimento: crescimento, maturação, maturidade fisiológica, amadurecimento e senescência (WATADA et al., 1984). Durante o crescimento do fruto, ocorre o aumento das células e, consequentemente, incremento de peso até o fruto atingir o tamanho final, além da biossíntese de novos compostos (AZZOLINI, 2002). A maturação é marcada por mudanças bioquímicas, fisiológicas e estruturais. Nessa fase, ocorre aumento da doçura, amaciamento e mudança da coloração pelo decréscimo da clorofila e desenvolvimento dos pigmentos como carotenoides e antocianinas. Atingindo a maturidade fisiológica, o fruto torna-se apto para consumo e normalmente é quando os frutos são colhidos.

Após esta etapa, inicia-se o amadurecimento, que é a fase final da maturação e quando começam os processos degradativos. Nessa fase, não há mais crescimento do fruto; ele apenas continua seu metabolismo utilizando os substratos acumulados e, assim, acontecem as principais transformações químicas: aumento do teor de sólidos solúveis e doçura devido ao aumento da concentração de frutose, de glicose e de sacarose, aumento do teor de vitamina C, decréscimo no teor de clorofila e aumento de carotenoides e antocianinas, além da solubilização das pectinas e da redução dos teores de ácidos orgânicos (AZZOLINI, 2002; WATADA et al., 1984). Já na senescência, iniciam-se as reações de degradação, causando envelhecimento e morte dos tecidos (WATADA et al., 1984).

Por ser uma fruta climatérica, ou seja, que amadurece após a colheita, a goiaba apresenta alta taxa respiratória, alta produção de etileno e alta sensibilidade a este hormônio; devido a isso, senescem rapidamente (JAIN et al., 2001). Consequentemente o fruto apresenta curto período de conservação necessitando ser comercializado rapidamente após a colheita.

Em geral, as frutas climatéricas podem ser colhidas antes que estejam maduras; no entanto, é muito importante que a colheita seja feita no estádio certo de maturação, uma vez que isso é determinante na sua composição química e, consequentemente, no seu valor nutricional e qualidades organolépticas (AZZOLINI; JACOMINO; BRON, 2004). Os frutos, se colhidos ainda imaturos, apresentam alto índice de perda de água, sabor e aroma inferior ao de quando amadurecem. Já, se colhidos maduros, entram rapidamente em senescência (AZZOLINI; JACOMINO; SPOTO, 2004). 
A maturação da goiaba é determinada com base na observação da cor da fruta, sendo consideradas três cores: verde clara, verde amarelada e amarela. A colheita é realizada de forma empírica, baseada apenas na cor da goiaba (SIQUEIRA, 2009). É importante lembrar que a máxima qualidade do fruto é obtida no momento da colheita.

No Brasil, a produção da goiaba é realizada durante todo o ano, o que só é possível devido às técnicas de produção que utilizam podas, irrigações e adubações. Há uma maior oferta em relação à demanda durante a safra (de janeiro a março), e (o oposto) é menor durante a entressafra, o que é muito importante pela inviabilidade de estocar matéria-prima para as indústrias dos produtos à base de goiaba.

Em relação à adubação da goiabeira, é fundamental conhecer os níveis corretos para elevar a produção mantendo a qualidade do fruto. Segundo Maia et al. (2007), ainda há poucos resultados de pesquisas realizadas no Brasil a fim de determinar verdadeiras necessidades nutricionais dessa cultura; com isso, a adubação da goiabeira é feita, geralmente, de forma empírica, ao contrário da maioria das frutíferas economicamente importantes para as quais são conhecidas as denominadas doses econômicas de nitrogênio, de fósforo e de potássio para cada tipo de solo. De acordo com Medeiros et al. (2004), a adubação nitrogenada proporcionou um incremento nas variáveis físicas, peso e diâmetro longitudinal, porém não influenciou o diâmetro transversal. Alguns trabalhos indicam alta resposta da goiabeira à melhoria da fertilidade do solo (NATALE et al., 2007). Entretanto, o aumento da produção à custa da elevação das doses de fertilizantes pode provocar uma redução na qualidade dos frutos, afetando, por exemplo, o tamanho, a coloração interna e externa e o teor de sólidos solúveis totais (NATALE et al., 1995).

Muitas vezes, a fertilização do solo pode afetar, mesmo que pouco, a quantidade de vitamina $\mathrm{C}$ presente no alimento. Estudos com batatas indicaram que um aumento na fertilização nitrogenada pode levar à diminuição da quantidade de vitamina $\mathrm{C}$ (LEE; KADER, 2000), o que também foi observado em árvores cítricas, enquanto o aumento da fertilização com potássio leva a um aumento da quantidade de ácido ascórbico (KADER, 1988).

Existem diferentes cultivares de goiaba, como a Kumagai, Sassaoka, Ogawa, Pedro Sato, Cascuda de Paeiquera-Açu e Iwao e quase todas ainda são cultivadas em várias partes do país, além das variedades Paluma, Rica e a variedade século 21, que foram desenvolvidas no programa de melhoramento genético de frutíferas pela Universidade Estadual Paulista (UNESP), campus Jaboticabal (WATANABE, 2009). A cultivar Paluma é uma das mais difundidas uma vez que apresenta boas características tanto para consumo in natura quanto 
para indústria. É uma goiaba de polpa vermelha que costuma ser produzida o ano todo; no entanto, a época mais favorável é entre janeiro e março. Jaboticabal, Catanduva e Araraquara são as principais produtoras desta cultivar. A Paluma tem como principal destino, a indústria, sendo que, nas regiões onde é mais produzida, existem várias indústrias locais de processamento. As plantas possuem alta capacidade produtiva (mais do que $50 \mathrm{t} \mathrm{ha}^{-1}$ ), frutos com bom rendimento e altos teores de sólidos solúveis totais. Apresentam alto vigor, o que proporciona boas respostas ao manejo de safra através da poda e da irrigação. Os frutos são grandes (mais de $200 \mathrm{~g}$ ), de casca lisa e de cor amarela quando madura, polpa de vermelho escuro intenso, firme e grossa $(1,3 \mathrm{a} 2,0 \mathrm{~cm})$ e apresentam sabor muito bom graças ao alto teor de sólidos solúveis $\left( \pm 10^{\circ} \mathrm{Brix}\right)$ (POMMER, 2006).

A cultivar Paluma também é produzida na região do submédio São Francisco e apresenta as características descritas na Tabela 2.

Tabela 2- Características físicas, físico-químicas e químicas de frutos da cultivar Paluma produzida na região do submédio São Francisco.

\begin{tabular}{|c|c|c|c|}
\hline \multicolumn{4}{|c|}{ Goiaba Paluma } \\
\hline Massa (g) & 104,8 & $\begin{array}{l}\text { Acidez total titulável } \\
\text {-ATT- (\% ác. Cítrico) }\end{array}$ & 0,63 \\
\hline $\begin{array}{c}\text { Diâmetro Longitudinal } \\
-\mathrm{DL}-(\mathrm{cm})\end{array}$ & 6,29 & RelaçãoSST/ATT & 17,63 \\
\hline $\begin{array}{c}\text { Diâmetro Transversal } \\
- \text {-DT- }(\mathrm{cm})\end{array}$ & 5,57 & $\mathrm{pH}$ & 3,88 \\
\hline Relação DL/DT & 1,13 & $\begin{array}{c}\text { Açúcares solúveis totais } \\
\text {-AST- }(\%)\end{array}$ & 4,61 \\
\hline $\begin{array}{c}\text { Sólidos solúveis totais } \\
\text {-SST-(Brix) }\end{array}$ & 10,4 & $\begin{array}{c}\text { Vitamina C } \\
\text { (mg ác. Ascórbico } / 100 \mathrm{~mL} \text { ) }\end{array}$ & 89,78 \\
\hline
\end{tabular}

Fonte: Lima; Assis; Neto (2002).

Vários autores enfatizam que há grandes variações nos teores desses componentes, mesmo dentro da mesma variedade do fruto, devido à influência de diferentes fatores pré e pós-colheita (KADER, 1988). Dentre os fatores pré-colheita, podem-se citar: i) condições climáticas, como temperatura, luz, vento e chuvas; ii) condições da cultura, como tipo de solo, 
poda, suprimento de água e nutrientes e iii) uso de produtos químicos agrícolas, como adubos orgânicos ou minerais (KADER, 1988), assim como o estádio de maturação no momento da colheita.

\subsection{Metabólitos}

Metabolismo (do grego metabolismos, $\mu \varepsilon \tau \alpha \beta o \lambda \imath \sigma \mu o ́ \varsigma$, que significa "mudança", troca) é o conjunto de transformações que as substâncias químicas sofrem no interior dos organismos vivos. Estas reações são responsáveis pelos processos de síntese e de degradação dos nutrientes na célula e constituem a base da vida, permitindo o crescimento e a reprodução das células, mantendo as suas estruturas e adequando respostas aos seus ambientes.

O metabolismo pode ser divido em primário e secundário (ROCHA et al., 2006). O metabolismo primário é essencial para o crescimento, para o desenvolvimento e para a manutenção das células, produzindo metabólitos primários. Já o metabolismo secundário não é essencial para o crescimento e para o desenvolvimento, mas para a sobrevivência e para a continuidade da espécie, produzindo metabólitos secundários específicos (BRAZ FILHO, 2010).

Metabólitos é o "conjunto de compostos de baixa massa molecular sintetizados por um organismo", "produtos finais da expressão de um gene que definem o fenótipo bioquímico de um organismo" e/ou "intermediários de reações bioquímicas que interligam várias rotas metabólicas em um sistema vivo" (FIEHN, 2002; VILAS-BÔAS et al., 2005).

Dentre os metabólitos primários das frutas, podem-se citar lipídios, proteínas e carboidratos. Já entre os metabólitos secundários, compostos bioativos como carotenoides e compostos fenólicos.

\subsubsection{Carboidratos}

Segundo Francisco Junior (2008), carboidratos são poliidroxialdeídos ou poliidroxicetonas, ou substâncias que, quando hidrolisadas, liberam tais compostos. Eles fazem parte de uma das maiores classes de biomoléculas e atuam como fonte energética, como elementos estruturais e como sinalizadores no organismo. Podem ser divididos em três 
classes principais de acordo com o número de ligações glicosídicas: monossacarídeos, oligossacarídeos e polissacarídeos.

\subsubsection{Monossacarídeos e oligossacarídeos}

Os monossacarídeos possuem de três a dez átomos de carbono em cadeia não ramificada, na qual um dos átomos de carbono é unido a um átomo de oxigênio, constituindo um grupo carbonila; os restantes são ligados a hidroxilas. São divididos em cetoses e aldoses, sendo que as estas com quatro carbonos e todos os outros monossacarídeos, com cinco ou mais átomos de carbono, apresentam-se cíclicos em solução aquosa (EL KHADEM, 1988). Os monossacarídeos redutores têm a capacidade de serem oxidados por íons cúpricos $\left(\mathrm{Cu}^{2+}\right)$ e férricos $\left(\mathrm{Fe}^{3+}\right)$, sendo a frutose e a glicose dois exemplos, além de os principais açúcares presentes nas frutas.

Os oligossacarídeos são carboidratos resultantes da união de duas a dez moléculas de monossacarídeos por ligação glicosídica (EL KHADEM, 1988). A ligação de uma molécula de glicose e uma de frutose leva à formação da sacarose, um dissacarídeo, sendo que essa ligação é facilmente hidrolisada por aquecimento com ácido diluído. Tal ligação ocorre pela condensação entre o grupo hidroxila de um monossacarídeo com o carbono anomérico de outro monossacarídeo. A sacarose não é um açúcar redutor já que suas extremidades redutoras estão ligadas por uma ligação glicosídica (FERNANDO JUNIOR, 2008).

Em geral, os monossacarídeos são sólidos cristalinos, polares e solúveis em água em temperatura ambiente, assim como os dissacarídeos, e possuem uma baixíssima absorção na região ultravioleta.

Os principais açúcares encontrados na goiaba são frutose, glicose e sacarose. A frutose corresponde a cerca de $60 \%$ dos açúcares totais; já a glicose e a sacarose correspondem a 35\% e 5\%, respectivamente. A proporção desses açúcares é o fator responsável pela doçura do fruto, sendo que a frutose é o mais doce. Considerando que a fruta tende a ficar mais doce com o desenvolvimento, o aumento da doçura está relacionado com a formação e com o acréscimo de frutose (CARVALHO, 1994; CHOUDHURY et al., 2001).

Monitorar esses açúcares é muito importante para áreas como nutrição, biologia e ciência de alimentos. Além disso, uns dos fatores mais importantes para a qualidade das frutas é o sabor, dado pelo balanço entre os açúcares solúveis e os ácidos orgânicos. Para a indústria 
processadora da goiaba, também é muito importante caracterizar a presença desses açúcares uma vez que, na quantidade adequada, evitam a necessidade da utilização de aditivos.

Diferentes métodos são utilizados para determinação de açúcares redutores e de açúcares totais em alimentos; dentre eles, os titulométricos (EDTA, Lane-Enyon e LuffSchoorl), gravimétricos (Musson-Walker) e espectrofotométricos (Fenol-Sulfúrico, SomogyiNelson e ADNS).

Um dos métodos mais utilizados é o ADNS (ácido 3,5-dinitrosalicílico) o qual é reduzido para ácido 3-amino-5-nitrossalicílico, enquanto o açúcar é oxidado. A mudança de cor é monitorada pela absorbância no comprimento de onda de $540 \mathrm{~nm}$ e o teor de açúcares redutores, quantificado utilizando-se uma curva de calibração analítica de glicose. No entanto, diferentes açúcares produzem diferentes intensidades de cor, pois a equivalência entre a quantidade de açúcar e o ácido aminonitrossalicílico produzido não é exata (SILVA; MONTEIRO; ALCANFOR; ASSIS; ASQUIERI, 2003).

Em geral, os métodos colorimétricos não são muito específicos; portanto não são capazes de identificar e de quantificar os açúcares individualmente. Para isso, tem sido utilizadas técnicas de separação, dentre elas:

- cromatografia em camada delgada (MOREIRA; SOUZA; VENDRUSCOLO, 1998);

- cromatografia líquida de alta eficiência com detector por índice de refração (HPLCRID) (AQUINO et al., 2004; GLYAD, 2002; GOUVEIA; NASCIMENTO; SOUTOMAIOR, 2009);

- cromatografia líquida de alta eficiência com detecção amperométrica pulsada (HPLCPAD) (BERNARDES-SILVA; LAJOLO; CORDENUNSI, 2003);

- cromatografia gasosa (GC) (MASON; SLOVER, 1971; ENGLYST; WIGGINS; CUMMINGS, 1982).

A utilização dos métodos cromatográficos é muito importante, no entanto seu uso envolve longos tempos de análises, além da necessidade de etapas extras no preparo de amostra para formação de derivados capazes de serem volatilizados para análise por GC, por exemplo.

A eletroforese capilar vem ganhando destaque na análise dos açúcares, pois é uma ferramenta poderosa de separação e pode promover alta resolução e eficiência. Além disso, em geral as amostras de alimentos podem ser analisadas com mínimo preparo de amostra, sem diminuir o desempenho da separação (SOGA; SERWE, 2000). Diferentes métodos são utilizados para análise de açúcares por eletroforese capilar. Dentre eles, métodos com 
detecção direta no UV, como no trabalho de Ramírez et al. (2004), que determinou carboidratos em bebidas utilizando derivação prévia com ácido $p$-aminobenzóico, sendo possível separar uma mistura de 7 açúcares redutores em 12 minutos. Alguns trabalhos utilizaram a detecção indireta, como Oefner et al. (1992), os quais concluíram que a utilização de reagentes, como etil $p$-aminobenzoato ou ácido $p$-aminobenzóico para derivação, proporciona boa reprodutibilidade na determinação de aldoses e de cetoses. No entanto, apesar de a detecção indireta ser menos sensível, permite a detecção dos açúcares excluindo a necessidade de mais uma etapa no preparo de amostra, sem a necessidade de derivação (JAGER, TONIN e TAVARES, 2007).

Outros trabalhos utilizaram eletroforese capilar com detecção condutométrica com contato (CCD), a qual demonstrou ser vantajosa devido à simplicidade no preparo da amostra, curto tempo de análises e boa detectabilidade (CARVALHO; SILVA; LAGO, 2003). Também são relatados trabalhos para determinação de carboidratos por eletroforese em microchip com detecção amperométrica (LEE; CHEN, 2004).

Os carboidratos são totalmente ionizados apenas em soluções com meio fortemente básico, uma vez que, em geral, apresentam pKa em torno de 12-13, como pode ser visto na Tabela 3.

Tabela 3- Valores de pKa de alguns carboidratos neutros

\begin{tabular}{c|c}
\hline Carboidrato & $\mathbf{p K}_{\mathbf{a}}$ \\
\hline Glicose & 12.35 \\
Frutose & 12.03 \\
Sacarose & 12.51 \\
\hline
\end{tabular}

Fonte: Rovio; Yli-Kauhaluoma; Sirén,(2007)

A utilização de eletrólito com pH fortemente básico na presença de borato de sódio, para análise de carboidratos por eletroforese capilar, requer pouco preparo de amostra devido a não necessidade de derivação. O método com a utilização de borato baseia-se na formação de um complexo negativamente carregado, capaz de absorver no ultravioleta (195 nm) (KUHN et al., 1991). Rovio, Yli-Kauhaluoma e Sirén (2007) determinaram carboidratos neutros utilizando uma solução eletrolítica fortemente básica consistindo de uma mistura de fosfato dissódico dihidratado $450 \mathrm{mmol} \mathrm{L}^{-1}$ e hidróxido de sódio $1 \mathrm{~mol} \mathrm{~L}^{-1}$. O método baseiase na formação de um enoldiolato em meio extremamente alcalino, o qual é estabilizado pela 
presença do cátion sódio, evitando a transformação dos açúcares em ácidos carboxílicos e detecção direta por absorção no UV do ânion formado (ROVIO et al., 2008; ROVIO, YLIKAUHALUOMA, SIRÉN, 2007).

\subsubsection{Pectinas}

Pectina é o nome genérico dado para a mistura de diferentes compostos, onde o ácido pectínico é o componente em maior concentração (KASHYAP et al., 2001). As pectinas são encontradas na parede celular primária e nas camadas intercelulares de plantas associadas à celulose, hemicelulose e lignina. Elas são polissacarídeos estruturais, os quais formam um grupo complexo de oligossacarídeos e polissacarídeos que possuem características comuns, mas são diversificadas quanto a sua estrutura fina. No entanto, todas são ricas em ácido galacturônico (WILLATS; KNOX; MIKKELSEN, 2006).

Segundo alguns autores, as pectinas são formadas por três frações principais:

- homogalacturonana (HG), que consiste em uma cadeia principal linear de unidades repetidas de $(1 \rightarrow 4)$ - $\alpha$-D-ácido galacturônico parcialmente esterificados como éster metílico;

- ramnogalacturonana I (RGI), que possui a mesma cadeia de ácido e é interrompida por unidades de $(1 \rightarrow 2)$ - $\alpha$-L-ramnose, às quais estão ligadas a cadeias laterais, formadas por açúcares neutros;

- ramnogalacturonana II (RGII), que possui uma cadeia principal de HG, com as cadeias laterais complexas unidas aos resíduos de ácido galacturônico (FISHMAN et al., 1984; FISSORE et al., 2010; WILLATS; KNOX; MIKKELSEN, 2006).

Os açúcares neutros presentes nas cadeias laterais são os responsáveis pela união das moléculas de pectina à matriz polissacarídica da parede celular vegetal (HWANG; KOKINI, 1992). O ácido D-galacturônico é o principal açúcar constituinte das substâncias pécticas, mas também fazem parte proporções variáveis de outros açúcares, como D-galactose (Gal), Larabinose (Ara), D-Xilose (Xyl) e L-ramnose (Rha) (HWANG; KOKINI, 1992; HWANG; PYUN; KOKINI, 1993). A presença principalmente da arabinose e galactose nas cadeias laterais afeta significativamente a solubilidade, geleificação, formação de filme e propriedades reológicas, além de favorecer agregação em soluções concentradas (FISHMAN et al., 1984; FISSORE et al., 2010; HWANG; KOKINI, 1992).

A composição, a estrutura e as propriedades fisiológicas das pectinas são influenciadas pelas condições de extração, de fonte e de outros fatores ambientais (FISSORE et al., 2010; 
IGLESIAS; LOZANO, 2004). As características químicas das pectinas, como grau de esterificação, massa molar, acetilação, grau de amidação, conteúdo de cinzas e composição monossacarídica, influenciam diretamente em uma das propriedades mais conhecidas da pectina: a formação de gel (THAKUR; SINGH; HANDA, 1997).

As pectinas são subdivididas em duas classes com relação ao seu grau de metoxilação: HMP, alto grau de metoxilação (maior que 50\%) e LMP, baixo grau de metoxilação (menor que 50\%). Pectinas HMP possuem grande poder geleificante e são muito utilizadas na geleificação de sucos de frutas para obtenção de geléias (IGLESIAS; LOZANO, 2004). O processo de geleificação é complexo e ainda há muita divergência quanto ao seu mecanismo (CHRONAKIS; KASAPIS; ABEYSEKERA, 1997).

Outra classificação para as substâncias pécticas é com relação às ligações da cadeia principal, que podem dividir-se em: protopectinas, ácido péctico, ácido pectínico e pectina.

As protopectinas são substâncias pécticas insolúveis em água, encontradas em tecidos de plantas e são utilizadas para produzir substâncias pécticas solúveis (pectina e pectinas ácidas) após hidrólise.

Os ácidos pécticos são galacturonanas contendo pequena quantidade de grupos metoxil, e os ácidos pectínicos são galacturonanas com teor variado de grupos metoxil, que formam gel na presença de açúcares e ácidos.

A pectina está diretamente relacionada à textura e firmeza do fruto, que é um atributo muito importante, pois define sua qualidade para o consumo "in natura" e para o processamento, além de contribuir para a vida útil da fruta pós-colheita, auxiliando na resistência ao transporte (CARVALHO, et al., 2001). O amaciamento do fruto de goiaba, por exemplo, durante o amadurecimento é atribuído à perda de firmeza dos tecidos e está associado a modificações e degradação dos componentes da parede celular, como pectinas, hemicelulose e celulose (CARVALHO et al., 2001; DUAN et al., 2008; GONÇALVES et al., 2006).

Industrialmente a pectina é muito importante e é utilizada como agente geleificador, estabilizante, espessante e, recentemente, como substituinte de açúcar e de gordura em alimentos dietéticos (IGLESIAS e LOZANO, 2004).

A pectina comercial é extraída de diferentes fontes, como cascas de cítricos e bagaço de maçã (FERTONANI, 2006; HWANG; KOKINI, 1992; VIRK; SOGI, 2004), além de fontes alternativas como girassol, abóbora, beterraba, maracujá (KLIEMANN, 2006) e outros (KUMAR; CHAUHAN, 2010). 
A goiaba é rica em pectinas, cujo teor é influenciado por fatores como variedade, estádio de maturação, época de desenvolvimento dos frutos e fatores climáticos (DHINGRA; GUPTA; CHUNDWAT, 1983). Devido à grande quantidade de pectinas, ela possui propriedades interessantes para obtenção de purês, que são reprocessados para néctares, para misturas de bebidas, para sucos, doces, geléias e xaropes, o que lhe dá grande aplicação industrial (LEITE et al., 2006). No entanto, durante o processamento da goiaba na indústria de alimentos, a necessidade de adição de pectina comercial aos produtos é comum quando se utiliza polpa concentrada em vez de fruta fresca no processo, constituindo um problema econômico na indústria (LEITE et al., 2009).

O processo de extração destes compostos pode ser realizado em meio aquoso ácido, básico, com agentes quelantes ou por ação de enzimas. Contudo a extração ácida geralmente resulta em pectinas de alto grau de esterificação, próximo do grau de esterificação de ocorrência natural (JOYE; LUZIO, 2000).

Diferentes ácidos são comumente utilizados para extração, como ácido fosfórico, acético, sulfúrico, entre outros, em $\mathrm{pH}$ variando de 1 a 3 , e temperatura entre 80 e $100{ }^{\circ} \mathrm{C}$; o ácido utilizado e as condições influenciam não somente no rendimento da extração como também na estrutura do produto final (LEVIGNE; RALET; THIBAULT, 2002; PAGÁN et al., 2001).

A utilização desses ácidos possui algumas desvantagens, como a geração de resíduos poluentes. Pensando nisso, muitos pesquisadores têm trabalhado para identificar condições ideais para utilização de ácidos orgânicos, como ácido cítrico, por exemplo, no intuito de obter uma pectina de boa qualidade beneficiando não somente a indústria, mas também o meio ambiente.

Alguns trabalhos utilizaram o ácido cítrico para extração de pectina de maçã (VIRK; SOGI, 2004), maracujá (KLIEMANN, 2006) e goiaba (MUNHOZ, SANJINEZARGANDOÑA; SOARES-JÚNIOR, 2008). No trabalho de Kumar e Chauhan (2010), observou-se que a extração de pectina com ácido cítrico foi mais eficiente e menos destrutiva para a cadeia polimérica.

Como dito anteriormente, a composição monossacarídica da pectina influencia na conformação molecular e, consequentemente, nas propriedades físicas da pectina (KRAVTCHENKI; VORAGEN; PILNIK, 1992). Para determinação da composição monossacarídica da pectina, é necessário realizar uma hidrólise, na qual comumente é utilizado o ácido trifluoracético (TFA) (ARNOUS; MEYER, 2009; BRANDÃO; ANDRADE, 
1999). No trabalho de Pinheiro (2007), foi utilizada hidrólise ácida para liberação dos açúcares neutros presentes na pectina e cromatografia gasosa acoplada a espectrometria de massa (GC-MS) para determinação destes açúcares. Para isso, foi necessário realizar, após a hidrólise, a redução e a posterior acetilação dos açúcares, os quais foram analisados por GCMS. A cromatografia gasosa também foi utilizada para determinar o conteúdo de açúcares neutros da pectina de bagaço de maçã, sendo que os principais deles foram a arabinose, a galactose e a glicose (FERTONANI, 2006). Já no trabalho de Hwang e Kokini (1992), determinou-se a galactose e a xilose como os maiores constituintes. Na determinação da composição monossacarídica da pectina de citros por cromatografia líquida, detectou-se a presença de xilose, glicose, arabinose, ramnose, galactose e ácido galacturônico, sendo que as maiores proporções de açúcares neutros encontradas foram de galactose e ramnose (LI et al., 2010).

A eletroforese capilar é outra técnica analítica utilizada para caracterizar a composição monossacarídica de polissacarídeos estruturais (XIA et al., 2010b). Um exemplo é o trabalho de Xia et al. (2010a), no qual se separaram e quantificaram monossacarídeos derivados com NMP (1-(2-naftil)-3-metil-pirazolona) provenientes de polissacarídeos de ervas medicinais. Embora a derivação dos carboidratos melhore a sensibilidade e a resolução, a complexidade da derivação tem desvantagens, como problemas na quantificação (XIA et al., 2011).

Recentemente, a detecção direta de carboidratos neutros por eletroforese capilar sem derivação tem sido realizada com reação no capilar e detecção direta na região UV no comprimento de onda de $270 \mathrm{~nm}$ (Rovio et al., 2007, 2008). Segundo Rovio e colaboradores (2007, 2008), o anion de absorção proposto, é o anion enediolato. Esse anion é formado como intermediário da reação de degradação de carboidratos à ácidos carboxílicos em $\mathrm{pH}$ fortemente básico. No entanto a presença do cátion sódio presente no eletrólito, preveni a reação de degradação, permitindo assim que esse permaneça em solução e absorva em 265 nm. Alguns trabalhos já utilizaram essa metodologia para caracterização monossacarídica de polissacarídeos estruturais (ROVIO et al., 2008; XIA et al., 2011).

\subsubsection{Vitamina C}

Vitaminas são oligossubstâncias sem valor energético próprio. Algumas vitaminas, como a vitamina $\mathrm{K}$, por exemplo, não precisam ser fornecidas por via alimentar ao organismo humano enquanto outras, como a vitamina $C$, precisam já que o homem não é capaz de 
sintetizá-la. As fontes de vitamina C são os legumes e as verduras, mas principalmente os frutos ácidos como caju, uva, limão e laranja. A acerola é bastante rica nessa vitamina, contendo valores muito superiores em relação aos outros citados (NELSON; COX, 2006). Além dessas fontes, alguns trabalhos destacaram a grande quantidade de vitamina $\mathrm{C}$ presente na goiaba (AZZOLINI; JACOMINO; BRON, 2004; BRUNINI; OLIVEIRA; VARANDA, 2003; LIMA et al., 2002). No Brasil, a Ingestão Diária Recomendada (IDR) de vitamina C para adultos é de $60 \mathrm{mg}$ (ANVISA, 1998).

A vitamina $\mathrm{C}$ ou ácido ascórbico é uma vitamina hidrossolúvel (NELSON; COX, 2006); é um nutriente de extrema importância para a fisiologia humana e sua deficiência provoca o escorbuto (ROSA et al., 2007); além disso, é responsável pela redução do risco de outras doenças degenerativas como câncer e doenças cardíacas, devido às suas propriedades antioxidantes (GARDNER et al., 2000). A atividade antioxidante da vitamina C envolve a transferência de um elétron ao radical livre, possuindo a capacidade de seqüestrar os radicais livres com grande eficiência (BARCIA et al., 2010).

Sua fórmula química é $\mathrm{C}_{6} \mathrm{H}_{8} \mathrm{O}_{6}$, e ela pertence à classe das lactonas, que são ácidos carboxílicos que se transformam em ésteres cíclicos pela perda espontânea de água.

A vitamina $\mathrm{C}$ compreende o ácido ascórbico na sua forma reduzida e o ácido deidroascórbico (DIA) na forma oxidada (LEE; KADER, 2000; NAGY, 1980) conforme Figura 1. O processo de conversão envolve a perda de dois elétrons, sendo um processo reversível. O ácido desidroascórbico possui de 60 a 100\% da atividade biológica do ácido Lascórbico (LIAO et al., 2001; TEIXEIRA et al., 2006).

Figura 1- Estrutura química e reação de equilíbrio entre ácido ascórbico e ácido desidroascórbico
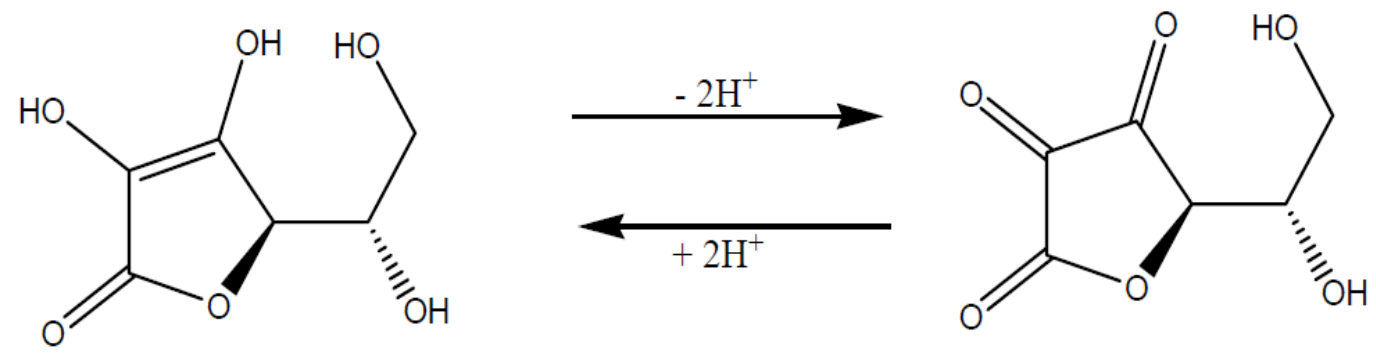

O ácido desidroascórbico pode ser reduzido ao ácido ascórbico por agentes redutores e oxidado irreversivelmente para ácido dicetogulônico, o qual não possui atividade vitamínica (PARVIAINEN; NYYSSONEN, 1992).

O ácido ascórbico pode ser produzido sinteticamente a partir de açúcar natural, uma dextrose (glicose, açúcar de mel, açúcar de milho). Este açúcar de fórmula química $\mathrm{C}_{6} \mathrm{H}_{12} \mathrm{O}_{6}$ 
se converte em ácido L-ascórbico $\left(\mathrm{C}_{6} \mathrm{H}_{8} \mathrm{O}_{6}\right)$ por reação de oxidação na qual quatro átomos de hidrogênio são removidos para formar duas moléculas de água.

Além de estar presente em muitos alimentos in natura, principalmente frutas e verduras, e ser muito importante para saúde, a vitamina $\mathrm{C}$ também é muito utilizada na indústria de alimentos como antioxidante para aromatizantes e para gorduras em geral, para cura de carnes, em farinhas para melhorar a textura das massas, em cerveja como estabilizante e para enriquecimento de vitamina C (ASSIS; LIMA; OLIVEIRA, 2001; CHIARI et al., 1993; ROSA et al., 2007) e em pães (LU; SEIB, 1998).

Nas plantas, a concentração de vitamina C (forma reduzida + forma oxidada) é influenciada por diferentes fatores como espécie, clima, luz, adubação e estádio de maturação (GOMEZ; LAJOLO, 2008; LEE; KADER, 2000; NAGY, 1980). O conteúdo destes nutrientes no alimento in natura e sua estabilidade podem influenciar na sua qualidade nutricional (LEE; KADER, 2000; SILVA, et al., 2006). É muito importante acompanhar a evolução da produção e das perdas de vitamina $\mathrm{C}$ durante o desenvolvimento do vegetal uma vez que essas informações podem determinar o tempo ideal de colheita para conseguir o maior teor de vitamina C (YAHIA; PADILHA; AGUILAR, 2001).

Em relação ao clima, estudos demonstraram que, em frutas, por exemplo, quanto maior a temperatura onde ela está desenvolvendo-se, menor a quantidade de vitamina $\mathrm{C}$ (NAGY, 1980). A luz também influencia, pois, apesar de não ser essencial para o desenvolvimento dessa vitamina, estudos demonstraram que os frutos com menos contato com o sol (que se desenvolveram na sombra) possuíam maior quantidade de vitamina $\mathrm{C}$ (NAGY, 1980).

A adubação potássica, por exemplo, influencia positivamente porque, em suco de laranja, de uva e de limão, houve um aumento da vitamina C com o aumento da dose de adubação. No entanto, altas doses de adubação nitrogenada tendem a diminuir o conteúdo de vitamina C em frutas e vegetais (LEE; KADER, 2000).

Durante a maturação de frutas ocorrem diferentes transformações, como mudança da coloração, síntese de açúcares e outras transformações, devido à fotossíntese e à respiração. Essas transformações podem levar ao stress do tecido e à necessidade da ação antioxidante, principalmente do ascorbato. Esse fenômeno pode explicar o motivo do ácido ascórbico decrescer em algumas frutas durante a maturação (BARATA-SOARES et al., 2004; SMIRNOFF; WHEELER, 2000). Em laranjas, em uvas e em tangerinas, a quantidade de vitamina C decresce durante o desenvolvimento na maturação (NAGY, 1980), mas em 
goiabas, em papaia e na água de coco, essa quantidade aumenta (AROUCHA; VIANNI, 2002; GOMEZ; LAJOLO, 2008).

A determinação da vitamina $\mathrm{C}$ em alimentos é desafiadora devido à necessidade de quantificação em diferentes matrizes e à grande sensibilidade a aquecimento, luz, presença de enzimas e exposição ao ar (ALMAGRO; ANDRES; VERA, 2002; FERNANDES et al., 2007).

Contudo, devido à grande importância da sua determinação tanto em alimentos quanto em outras matrizes, inúmeras técnicas analíticas têm sido propostas; dentre elas:

- espectrofotometria (GUÇLU et al., 2005; LISIEWSKA; KMIECIK, 1996);

- titulometria (AROUCHA; VIANNI, 2002; OKIEI et al., 2009);

- voltametria (IJERI; JAISWAL; SRIVASTAVA, 2001; POURNAGHI-AZAR; OJANI, 1997);

- fluorimetria (WU et al., 2003);

- cromatografia (AROUCHA; VIANNI, 2002; BARCIA et al., 2010; BARROS et al., 2010; CAMPOS et al., 2009; LYKKESFELDT, 2000; CARRIEDO; BUSLIG; SHAW, 1992; NOJAVAN, et al., 2008; ROSA et al., 2007; WILLS; WIMALASIRI; GREENFIELD, 1984);

- eletroforese capilar (LING et al., 1992; KOH, BISSELL; ITO, 1993; THOMPSON e TRENERRY, 1995; FUKUSHI et al., 1997; GALIANA-BALAGUER et al., 2001; LIAO et al., 2001; VERSARI et al., 2004; TANG e WU, 2005).

A maioria desses métodos pode superestimar os níveis de vitamina $\mathrm{C}$ devido à presença de espécies oxidáveis, no caso da utilização de métodos espectrofotométricos, a presença de outras espécies que absorvam na região do ultravioleta (OKIEI et al., 2009). Além disso, alguns desses métodos, como o titulométrico, por exemplo, conseguem determinar apenas o ácido L-ascórbico, não levando em conta a forma oxidada, o ácido Ldesidroascórbico (DIA) (MILLS; DAMRON; ROE, 1949). Roe e Oesterling (1994) fizeram modificações no método colorimétrico para determinação das duas formas, porém alguns autores afirmam que esse método pode superestimar a quantidade de DIA por causa de alguns interferentes, levando a erros na quantificação (MILLS; DAMRON; ROE, 1949; WILLS; WIMALASIRI; GREENFIELD, 1984).

Em alguns trabalhos utilizando a cromatografia líquida, foi possível determinar simultaneamente o ácido ascórbico e o ácido desidroascórbico utilizando detectores com arranjo de diodos (GEIGERT; HIRANO; NEIDLEMAN, 1981; CARRIEDO; BUSLIG; 
SHAW, 1992; WILLS; WIMALASIRI; GREENFIELD, 1984). No entanto, o ácido desidroascórbico possui o máximo de absorção próximo de $215 \mathrm{~nm}$ e baixa absortividade molar; por isso, alguns autores preferem a determinação indireta (CHIARI et al., 1993; LYKKESFELDT, 2000).

A determinação indireta do ácido desidroascórbico é realizada pela subtração da concentração de ácido ascórbico da concentração de ácido ascórbico total, determinada após a redução do ácido desidroascórbico presente (CHIARI et al., 1993; LYKKESFELDT, 2000). Para redução do ácido desidroascórbico, são utilizados agentes redutores diferentes; dentre eles: a D,L-homocisteína (CHIARI et al., 1993; ROSA et al., 2007), D,L-ditiotreitol (ROSA et al., 2007; THOMPSON e TRENERRY, 1995) e L-cisteina (SCHIEWE; MRESTANI; NEUBERT, 1995; VERSARI et al., 2004; ZERDIN, ROONEY e VERMUE et al., 2003).

A eletroforese capilar também é muito utilizada para determinação de ácido ascórbico e desidroascórbico, além de outras vitaminas, principalmente quando se utiliza detecção por arranjo de diodos, permitindo acompanhar uma faixa de comprimento de onda. Esta técnica apresenta vantagens como curto tempo de análise, baixo consumo de amostra e alta eficiência na separação (TANG; WU, 2005). No trabalho de Schiewe, Mrestani e Neubert (1995), foi possível determinar ácido ascórbico, tiamina, nicotinamida e ácido nicotínico em uma única análise acompanhando a faixa de comprimento de onda de 190 a $600 \mathrm{~nm}$.

A eletroforese capilar em zona (CZE) tem sido cada vez mais utilizada para determinação de ácido ascórbico, ácido ascórbico total e ácido desidroascórbico $(\mathrm{KOH}$; BISSELL; ITO, 1993; FUKUSHI et al., 1997; LIAO et al., 2001; LING et al., 1992; VERSARI et al., 2004). Na determinação de ácido ascórbico em frutas do gênero Lycopersicon, o método de CZE utilizando tampão borato demonstrou ser rápido, simples, barato e com baixo consumo de amostra em relação a outros utilizados na literatura, além de proporcionar baixo limite de detecção (GALIANA-BALAGUER et al., 2001). Chiari et al. (1993) utilizaram um método simples de CZE para determinação de ácido ascórbico total em frutas, utilizando homocisteína como agente redutor do ácido desidroascórbico. A análise foi realizada em nove minutos em um capilar recoberto utilizando tampão fosfato como eletrólito de separação; observou-se concordância com os resultados obtidos por cromatografia líquida. Thompson e Trenerry (1995) determinaram o L-ácido ascórbico total em várias frutas e verduras pelo método de cromatografia eletrocinética micelar (MEKC), utilizando o D,Lditiotreitol antes das análises para reduzir o ácido desidroascórbico à ácido ascórbico. Os autores compararam a utilização da eletroforese com a cromatografia líquida, chegando à 
conclusão de que a MEKC teve a mesma ordem de repetibilidade, além de ter sido mais rápida que a cromatografia líquida.

Para extração da vitamina C, é importante lembrar que ela é facilmente oxidada, levando à degradação irreversível. Por isso, os métodos de extração devem aumentar a estabilidade do ácido ascórbico recém-extraído da matriz, o que só é possível utilizando um meio extrator adequado e controlando as condições de manipulação como luz e temperatura, pois essas variáveis afetam significantemente a recuperação do ácido ascórbico (ROSA et al., 2007). É comum a homogeneização da amostra de frutas frescas e de vegetais em ácido uma vez que o meio ácido é capaz de estabilizar o ácido ascórbico, reduzindo a ação enzimática (CAMPOS et al., 2009; WIMALASIRI; WILLS, 1983).

Entre as soluções mais utilizadas para extrair o ácido ascórbico e também estabilizá-lo, podem-se citar: o ácido oxálico (ASSUNÇÃO; MERCADANTE, 2003; KABASAKALIS; SIOPIDOU; MOSHATOU, 2000; KE et al., 1994; ROSA et al., 2007), ácido metafosfórico (KOH, BISSELL; ITO, 1993; THOMPSON; TRENERRY, 1995; VERSARI et al., 2004; WIMALASIRI; WILLS, 1983) e ácido cítrico (ROSA et al., 2007; THOMPSON; TRENERRY, 1995; WIMALASIRI; WILLS, 1983), entre outros ( FUKUSHI et al., 1997). Estes ácidos são capazes de prevenir a oxidação do ácido ascórbico pela ação de íons cobre (II) ou ferro (III). Ao ácido metafosfórico também é reportada a habilidade de precipitar proteínas e, com isso, inativar enzimas (ROSA et al., 2007), no entanto é um reagente caro e tóxico (HERNÁNDEZ; LOBO; GONZÁLEZ, 2006). Soluções de EDTA também são citadas como fatores de estabilização do ácido ascórbico uma vez que íons como ferro e cobre aumentam a oxidação do ácido ascórbico (CAMPOS et al., 2009; HERNÁNDEZ; LOBO; GONZÁLEZ, 2006; ROSA et al., 2007).

\subsubsection{Carotenoides}

Os carotenoides constituem um dos mais importantes grupos de pigmentos naturais (CARDOSO, 1997). Eles são responsáveis pelas cores laranja, amarela e vermelha das frutas, das hortaliças, das flores, entre outros (RIBEIRO; SERAVALLI, 2004; RODRIGUEZAMAYA, RODRIGUEZ; AMAYA-FARFAN, 2006).

São definidos como tetraterpenóides $\mathrm{C} 40$, ou seja, como a união de oito unidades isoprenóides C5 formando uma cadeia carbônica de quarenta átomos de carbono (exceto a crocetina e a bixina que possuem menos), unidas a uma série de duplas ligações conjugadas, o 
que lhes confere a característica cromófora (CARDOSO, 1997; FELTL et al., 2005; RODRIGUEZ-AMAYA， 1997; RODRIGUEZ-AMAYA; RODRIGUEZ; AMAYAFARFAN, 2006).

Os sistemas de duplas ligações podem variar em quantidade proporcionando diferentes bandas de absorção e possibilidade de configuração cis e trans. Sete ou mais duplas ligações conjugadas conferem a capacidade de absorver a luz na região do visível, o que possibilita a esses compostos absorverem fortemente na faixa entre 400 e $500 \mathrm{~nm}$ e serem facilmente monitorados por detectores UV-Vis (CARDOSO, 1997; FELTL et al., 2005; RODRIGUEZAMAYA, 1997).

Esses pigmentos, em geral, absorvem maximamente em três comprimentos de onda, resultando num espectro com três picos, característica importante na identificação e na quantificação dos carotenoides. $\mathrm{O}$ aumento do número de duplas ligações faz com que o comprimento de onda absorvido seja maior e, consequentemente, mais intensa é a cor do carotenoide (FELTL et al., 2005; RODRIGUEZ-AMAYA, 2001). Os carotenoides são lipossolúveis, possuem propriedades antioxidantes, isomerizam facilmente e, por serem cromóforos, podem ser utilizados como corantes (RODRIGUEZ-AMAYA, 1997).

Os carotenoides podem ser classificados como pró-vitamínicos (precursores da vitamina A), entre os quais o $\beta$-caroteno é um dos mais importantes (RODRIGUEZ-AMAYA, 1997), ou inativos, que atuam apenas como antioxidantes dando cor aos alimentos. Quimicamente são divididos em carotenoides hidrocarbonetos (carotenos) e carotenoides oxigenados (xantofilas) (BEM-AMOTZ; FISHLER, 1998; FELTL et al., 2005; MORAIS, 2006; RODRIGUEZ-AMAYA, 1997; RODRIGUEZ-AMAYA; RODRIGUEZ; AMAYAFARFAN, 2006), que também podem ser subdivididos em sete grupos.

As principais fontes de carotenoides são vegetais; nestes se localizam em raízes, folhas, talos, semente, frutas e flores (BAUERNFEIND, 1972). Algumas frutas e vegetais possuem maiores concentrações de carotenoides na casca que na polpa, com exceção de frutas como a goiaba vermelha cuja polpa é rica em licopeno (RODRIGUEZ-AMAYA, 1993).

Destacam-se como fontes de carotenoides os vegetais folhosos, ricos em $\beta$-caroteno (RODRIGUEZ-AMAYA, 1997), culturas de raiz como cenoura, ricas em $\beta$ e $\alpha$-caroteno, e abóboras, também ricas em $\beta$ e $\alpha$-caroteno (RODRIGUEZ-AMAYA, 1997; BEM-AMOTZ; FISHLER, 1998; MULLER, 1997). As frutas também são fontes muito importantes; dentre elas: 
- tomate, rico em licopeno (MULLER, 1997; RODRIGUEZ-AMAYA; RODRIGUEZ; AMAYA-FARFAN, 2006; SILVA et al., 2011);

- manga, rica em provitamina $\mathrm{A}$; mamão, rico em provitamina $\mathrm{A}$ e licopeno (BEMAMOTZ; FISHLER, 1998; CHAROENSIRI et al., 2009; MERCADANTE; RODRIGUEZ-AMAYA, 1998; MULLER, 1997; RODRIGUEZ-AMAYA, 1997; SCHWEIGGERT et al., 2011; SENTANIN; RODRIGUEZ-AMAYA, 2007; SETIAWAN et al., 2001; WILLBER; RODRIGUEZ-AMAYA, 1995);

- abacate (LU et al., 2009), pitanga (BEM-AMOTZ; FISHLER, 1997), goiaba, ricos em licopeno (BEM-AMOTZ; FISHLER, 1997; FERNANDES, 2007; GONZÁLEZ et al., 2011; PADULA; RODRIGUEZ-AMAYA, 1986; SETIAWAN et al., 2001; WILLBER e RODRIGUEZ-AMAYA, 1995).

Cada vez mais há evidências do papel importante dos carotenoides, provitaminas A ou não, na redução do risco de doenças degenerativas tais como doenças cardiovasculares, catarata e degeneração muscular (RODRIGUEZ-AMAYA, 1997; RODRIGUEZ-AMAYA; RODRIGUEZ; AMAYA-FARFAN, 2006).

Os carotenoides mais estudados em relação à saúde humana são $\beta$-caroteno $(\beta, \beta$ caroteno), $\alpha$-caroteno ( $\beta, \varepsilon$-caroteno) e licopeno ( $\psi, \psi$-caroteno) (RODRIGUEZ-AMAYA; RODRIGUEZ; AMAYA-FARFAN, 2006). Devido aos carotenoides serem uns dos constituintes de alimentos mais abundantes na prevenção do câncer e de outras doenças degenerativas, sua determinação e sua quantificação têm-se tornado muito importantes, principalmente em frutas e em vegetais.

O tomate possui grande destaque como fonte de licopeno; no entanto, recentemente verificou-se que a goiaba vermelha oferece quantidades significantemente maiores e tem-se tornado uma importante fonte de $\beta$-caroteno e licopeno (Figura 2). Este, apesar de não possuir atividade pro-vitamínica, é o grande responsável pela coloração vermelha da polpa e apresenta um efeito protetor de radicais livres (FERNANDES, 2007; GONZÁLEZ et al., 2011; PADULA; RODRIGUEZ-AMAYA, 1986). 
Figura 2- Estruturas química dos principais carotenoides presentes na goiaba: (A) $\beta$-caroteno; (B) licopeno.<smiles>CC(C)=CCCC(C)=CC=CC(C)=CC=CC(C)=CC=CC=C(C)C=CC=C(C)C=CC=C(C)CCC=C(C)C</smiles>

Diferentes fatores podem afetar o conteúdo e a composição de carotenoides nos vegetais, como fatores genéticos, grau de maturação, condições de cultivo, condições climáticas, entre outros (SETIAWAN et al., 2001; SOUZA et al., 2004; RODRIGUEZAMAYA, 2001; RODRIGUEZ-AMAYA; RODRIGUEZ; AMAYA-FARFAN, 2006).

A exposição das plantas ao sol e a altas temperaturas durante o desenvolvimento leva ao aumento da biossíntese dos carotenoides (RODRIGUEZ-AMAYA; RODRIGUEZ; AMAYA-FARFAN, 2006).

É possível observar que, na maioria das frutas e dos vegetais que possuem carotenoides, o conteúdo de clorofila decresce com a maturação, deixando para os carotenoides a responsabilidade pelas cores. Isso ocorre porque geralmente há um aumento da carotenogênese durante a maturação, ou seja, ocorre um aumento dos carotenoides em número e em quantidade (RODRIGUEZ-AMAYA; RODRIGUEZ; AMAYA-FARFAN, 2006).

Mesmo em vegetais de folhas verdes foi observado um aumento do $\alpha-\gamma$ - $\beta$-caroteno com a maturação (RODRIGUEZ-AMAYA, 1997). Em dois cultivares de mangas, não foi observado variação na composição dos carotenoides com a maturação do fruto; no entanto, foi observado um aumento considerável da concentração desses compostos (MERCADANTE; 
RODRIGUEZ-AMAYA, 1998) assim como para diferentes cultivares de abacate (LU et al., 2009).

Silva et al. (2011) não observou influência significativa nos teores de carotenoides de diferentes cultivares de tomate em relação à adubação com diferentes doses de fósforo e de potássio.

A identificação dos carotenódes nos alimentos é extremamente difícil devido ao grande número de carotenoides naturalmente existentes nos alimentos, além do fato das moléculas serem extremamente insaturadas, o que os torna mais propícios a sofrerem isomeração, oxidação e degradação durante sua análise (RODRIGUEZ-AMAYA, 1996; RODRIGUEZ-AMAYA, 1997).

A maior causa de perda de carotenoides é por oxidação enzimática e não enzimática, o que depende da disponibilidade de oxigênio e da estrutura do carotenoide. Além disso, essa oxidação é estimulada pela luz, calor, metais, enzimas e peróxidos, podendo ser inibida por antioxidantes (RODRIGUEZ-AMAYA; RODRIGUEZ; AMAYA-FARFAN, 2006). Por serem de fácil degradação, a extração dos carotenoides deve ser feita rapidamente a fím de se evitar o contato com luz, oxigênio e altas temperaturas.

Em geral são mais utilizados solventes apolares para a extração de carotenoides, entre os quais o éter de petróleo e o éter etílico. Outros solventes também são utilizados; entretanto os carotenoides apresentam muitas desvantagens como o fato de serem inflamáveis, tóxicos e degradarem rapidamente. Solventes mais polares, como acetona, metanol e etanol, também são utilizados para extração (RODRIGUEZ-AMAYA, 1997), sendo mais comum a utilização de metanol e de acetona, que removem água e xantofilas mais hidrofílicas, seguida pela extração com solvente apolar como éter de petróleo, por exemplo (FELTL et al., 2005).

A separação e a identificação dos carotenoides é comumente realizada por cromatografia clássica de coluna aberta (CCA) ou por cromatografia líquida de alta eficiência (HPLC). A cromatografia gasosa (GC) não é muito apropriada já que os carotenoides são termolábeis e possuem baixa volatilidade (RODRIGUEZ-AMAYA, 1997).

A determinação de carotenoides por CCA é comumente realizada aplicando a amostra solubilizada em éter de petróleo em uma coluna de vidro empacotada com celite e óxido de magnésio. Éter de petróleo, éter etílico e acetona são utilizados como fase móvel, sendo que as frações eluídas são todas transferidas para éter de petróleo por partição. A determinação dos carotenoides é realizada pela comparação do espectro de absorção UV-Vis $(350$ - 550 nm) com os descritos na literatura. Para quantificação, utiliza-se a lei de Lambert-Beer, 
considerando a absorção máxima ( $\left.\lambda_{\text {máx }}\right)$ e os coeficientes de absortividade molar encontrados na literatura (MOREIRA, 2011; PADULA; RODRIGUEZ-AMAYA, 1986).

A cromatografia líquida de alta eficiência (HPLC) em fase reversa e detecção no UVVis é uma das técnicas mais utilizadas para determinação de carotenoides em alimentos. A composição dos carotenoides, em geral, é determinada de acordo com a coeluição, tempo de retenção e perfil de absorção em relação aos padrões; a quantificação é realizada por padronização externa com cada carotenoide disponível (ASSUNÇÃO; MERCADANTE, 2003; BEM-AMOTZ; FISHLER, 1998; CHAROENSIRI et al., 2009; HULSHOF et al., 1997; KIMURA et al., 2007; MULLER, 1997; SENTANIN; RODRIGUEZ-AMAYA, 1997; SETIAWAN et al., 2001; WILLBER; RODRIGUEZ-AMAYA, 1995).

Um estudo de 17 frutas e de 17 vegetais comumente consumidos em Israel foi realizado com o intuito de determinar a composição dos carotenoides e de quantificá-los por HPLC em fase reversa (C18) e a detecção por arranjo de fotodiodos. Quatorze carotenoides foram determinados e quantificados. Dentre as frutas e os vegetais estudados, determinou-se que pitanga, manga, mamão, cenoura, tomate, alface, batata doce e pimenta estão entre as fontes mais ricas de carotenoides (BEM-AMOTZ e FISHLER, 1998).

Em outro estudo de 22 espécies de vegetais e 28 frutas por HPLC em fase reversa com detecção no UV-Vis por arranjo de fotodiodos, foi possível determinar que o $\beta$-caroteno, a luteína e a violaxantina são os carotenoides predominantes em vegetais verdes. Vegetais e frutas amarelos e amarelo-avermelhados apresentaram, como principais carotenoides, $\beta$ caroteno, $\alpha$-caroteno, $\beta$-criptoxantina e $\alpha$-criptoxantina; licopeno foi o principal carotenoide encontrado em tomate e em uva (MULLER, 1997).

Willberg e Rodriguez-Amaya (1995) determinaram por HPLC que $\beta$-caroteno e licopeno são os principais carotenoides presentes na goiaba, enquanto demais carotenoides são encontrados apenas em quantidades traço.

A utilização da eletroforese capilar para determinação de carotenoides e de outros pigmentos naturais foi abordada em vários trabalhos. Os modos de eletroforese mais utilizados são: eletrocromatografia capilar (CEC) (ADALID et al., 2007), eletrocromatografia micelar (MECK) (WATANABE et al., 1997) e eletroforese em soluções não aquosas (NACE) (BELIN; GULAÇAR, 2007), uma vez que os carotenoides são moléculas neutras com alta hidrofobicidade, além de possuírem propriedades similares. Sendo assim, a utilização da eletroforese capilar em solução livre não é muito conveniente para separação desses compostos (BELIN; GULAÇAR, 2007). 
Belin e Gulaçar (2007) avaliaram diferentes modos de eletroforese capilar, CEC, MECK e NACE, sendo que a NACE demonstrou ser mais eficiente na separação de carotenoides e clorofilas, além de a metodologia ser simples, rápida e sensível. 


\section{OBJETIVOS}

\subsection{Objetivo geral}

Este trabalho teve por objetivo estudar a goiaba vermelha, cultivar Paluma, proveniente de goiabeiras adubadas com diferentes doses de nitrogênio e dose fixa de adubação potássica, avaliando características físicas e químicas relacionadas com o valor nutritivo, comercial e industrial da mesma.

\subsection{Objetivos específicos}

- Caracterização física dos frutos, diâmetros: transversal e longitudinal;

- Avaliação das características físico-químicas da goiaba por análises clássicas: Determinação do $\mathrm{pH}$, índice de polifenóis totais (IPT), acidez total titulável (ATT), sólidos solúveis totais - ${ }^{\circ}$ BRIX (SST), relação SST/ATT, açúcares redutores totais;

- Determinação e identificação dos principais metabólitos secundários como $i$ ) mono e dissacarídeos livres, ii) caracterização dos açúcares neutros presentes na pectina, iii) vitamina $\mathrm{C}$ e $i v$ ) carotenóides por técnicas eletroforéticas e cromatográficas. 


\section{MATERIAIS E MÉTODOS}

\subsection{Coleta e armazenamento das amostras}

As goiabas, provenientes do pomar pertencente à Indústria de Polpas e Conservas VAL Ltda em Vista Alegre do Alto-SP, região de Jaboticabal, foram coletadas em quatro estádios diferentes de desenvolvimento, como segue:

- Coleta 1: Três meses após o florescimento, fruto pequeno, interior branco e casca verde escura;

- Coleta 2: Quatro meses após o florescimento, fruto de tamanho intermediário, interior branco para rosado e casca verde clara;

- Coleta 3: Final do quarto mês após o florescimento, frutos maiores com relação aos anteriores, interior rosado e casca amarela-esverdeada;

- Coleta 4: Cinco meses após o florescimento, frutos grandes, maduros, interior vermelho, casca com coloração amarela e tamanho ideal para colheita $( \pm 7,5$ a $8,0 \mathrm{~cm})$.

Na Figura 5 é possível observar uma imagem das amostras nas quatro coletas distintas.

Figura 3: Goiabas coletadas em 4 diferentes estádios de desenvolvimento.

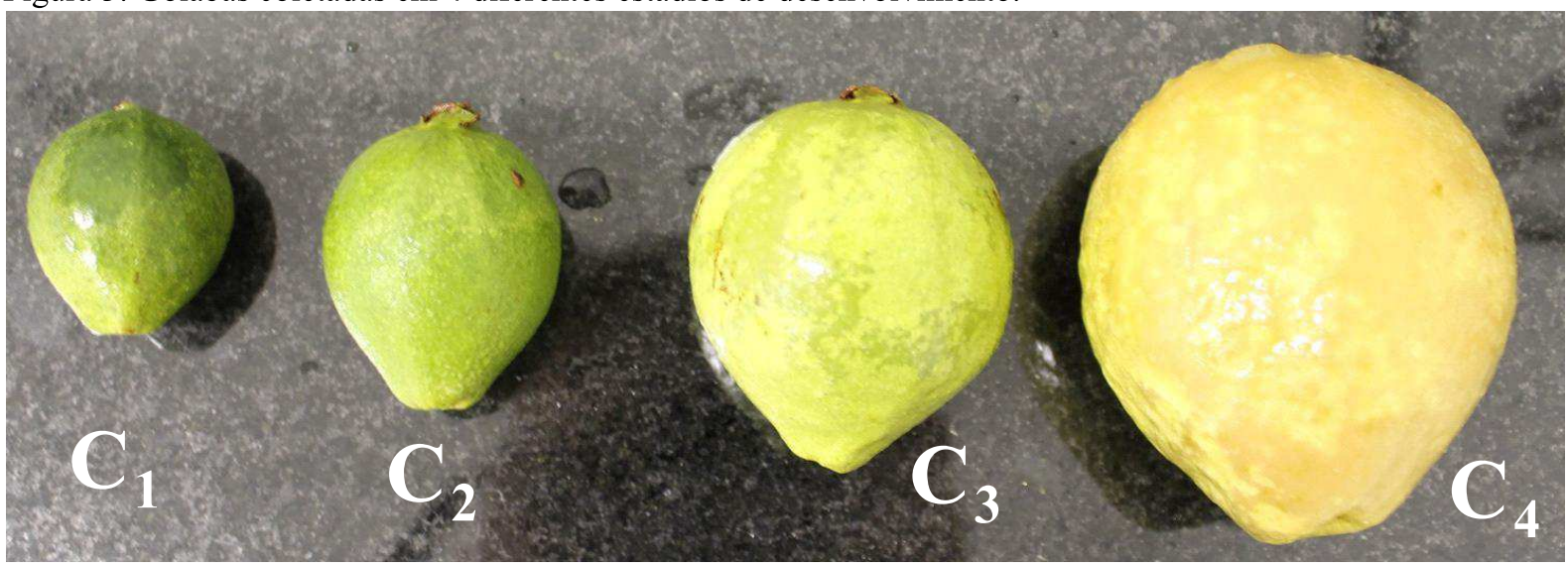

As coletas foram realizadas no período de maio a julho de $2010\left(\mathrm{C}_{1}, \mathrm{C}_{2}, \mathrm{C}_{3}\right.$ e $\left.\mathrm{C}_{4}\right)$, e uma segunda etapa de coletas foi realizada entre fevereiro e março de 2012 para comparação dos teores de vitamina C., sendo que na segunda etapa de coletas (2012), foram realizadas apenas as coletas $\mathrm{C}_{3}$ e $\mathrm{C}_{4}$. 
As goiabas coletadas foram provenientes de goiabeiras adubadas com $2200 \mathrm{~g}$ de cloreto de potássio $(60 \%$ de $\mathrm{K}$ ) e doses diferenciadas de nitrogênio (uréia, $45 \%$ de $\mathrm{N}$ ), sendo elas: (a) zero de nitrogênio $\left(\mathrm{N}_{0}\right)$, (b) $500 \mathrm{~g}\left(\mathrm{~N}_{1}\right)$, (c) $1000 \mathrm{~g}\left(\mathrm{~N}_{2}\right)$, (d) $2000 \mathrm{~g}\left(\mathrm{~N}_{3}\right)$.

A coleta de 12 frutos de cada adubação, em um total de 48 frutos por coleta, foi realizada aleatoriamente. Os frutos foram acondicionados em sacos plásticos devidamente etiquetados e transportados em caixas de isopor com gelo. Em seguida foram armazenados em freezer a $-18^{\circ} \mathrm{C}$ e identificados em relação a coleta $\left(\mathrm{C}_{1}, \mathrm{C}_{2}, \mathrm{C}_{3}\right.$ e $\left.\mathrm{C}_{4}\right)$ e tipo de adubação $\left(\mathrm{N}_{0}\right.$, $\mathrm{N}_{1}, \mathrm{~N}_{2}$ e $\mathrm{N}_{3}$ ).

As amostras foram divididas em duas partes, sendo a primeira utilizada para caracterização física de tamanho, que em seguida foi triturada em um multiprocessador para as análises físico-químicas, açúcares e pectinas, e novamente armazenadas em freezer a -18 ${ }^{\circ} \mathrm{C}$. A segunda foi utilizada para as análises de carotenóides e vitamina $\mathrm{C}$, sendo que as extrações foram realizadas logo após as amostras serem trituradas, uma vez que esse processo pode causar a perda desses compostos por oxidação.

\subsection{Caracterização do tamanho}

O diâmetro transversal (DT) e diâmetro longitudinal (DL) das goiabas foram determinados com auxilio de um paquímetro Mitutoyo com duas casas decimais de precisão. Foram realizadas 3 medidas por fruto, sendo que no total foram analisados 12 frutos de cada adubação, por coleta.

\section{3 Caracterização química}

\subsubsection{Determinação do $\mathrm{pH}$}

$\mathrm{O}$ pH foi medido diretamente de extratos aquosos de goiaba triturada, com um pHmetro digital Digimed, à temperatura ambiente.

\subsubsection{Polifenóis totais}

Para quantificação dos polifenóis totais os extratos de goiaba trituradas foram diluídos 101 vezes com água. Em seguida foi feita a leitura da absorbância em $280 \mathrm{~nm}$ em um 
espectrofotômetro UV-Vis (Jasco V-630) (MARTINEZ, MELGAREJO e HERNADEZ, 2001; RIBÉREAU-GAYON et al., 2006). O índice de polifenóis totais foi obtido pela leitura direta da diluição preparada e determinado pela Equação 1.

$$
I P T=D_{280} \times 101
$$

onde:

IPT $=$ índice de polifenóis totais e $\mathrm{D}_{280}=$ absorbância obtida a $280 \mathrm{~nm}$.

\subsubsection{Acidez total titulável}

A acidez total titulável foi determinada por titulometria. A uma alíquota de $3 \mathrm{~g}$ de goiaba triturada foram adicionados $40 \mathrm{~mL}$ de água e as amostras homogeneizadas por $30 \mathrm{~min}$ em agitador magnético. Em seguida, $5 \mathrm{~mL}$ da solução foi transferida para um erlenmeyer e titulada com $\mathrm{NaOH} 0,1 \mathrm{~N}$ previamente padronizado, utilizando-se fenolftaleína como indicador. A acidez total titulável (meq $\mathrm{L}^{-1}$ ) foi determinada pela Equação 2 (MINISTÉRIO DA AGRICULTURA, 1986).

$$
A t=\frac{1000 \times n \times N}{[]}
$$

onde:

$\mathrm{A}_{\mathrm{t}}=$ acidez total titulável

$\mathrm{n}=$ volume de $\mathrm{NaOH}$ gasto na titulação $(\mathrm{mL})$

[] = concentração da solução de $\mathrm{NaOH}$

$\mathrm{V}=$ volume de $\operatorname{amostra}(\mathrm{mL})$

\subsubsection{Determinação de sólidos solúveis totais - ${ }^{\circ}$ Brix}

A determinação de sólidos solúveis totais foi realizada por refratometria, utilizando um refratômetro Abbe modelo 2WAJ. O equipamento foi previamente calibrado com água para a leitura de índices de refração em 1,3330 a $25^{\circ} \mathrm{C}$, seguido por soluções de glicose. A presença de sólidos solúveis na água resulta em uma alteração deste valor, sendo que esta 
propriedade é utilizada para determinar a concentração de sólidos solúveis em soluções aquosas de açúcar (INSTITUTO ADOLFO LUTZ, 2008). Três gotas da solução de amostra homogeneizada como descrito anteriormente foram transferidas para o prisma do refratômetro e leu-se diretamente na escala o valor em ${ }^{\circ}$ Brix, considerando a diluição para o resultado final.

\subsubsection{Açúcares redutores totais}

Os açúcares redutores totais foram quantificados por espectrofotometria, de acordo com o método do ácido 3,5-dinitrosalicílico (ADNS). Para o preparo do reagente ADNS misturou-se uma solução $1 \%$ de DNS a $30 \%$ de tartarato de sódio e potássio em $\mathrm{NaOH} 0,4$ mol L $\mathrm{L}^{-1}$, aquecendo levemente para solubilização . A solução foi armazenada no escuro para evitar degradação. Para quantificação utilizou-se uma curva de calibração de glicose com concentrações entre 0,2 e $1,0 \mathrm{mg} \mathrm{mL}^{-1}$.

A uma alíquota de $400 \mu \mathrm{L}$ da solução de goiaba homogeneizada em água adicionou-se $400 \mu \mathrm{L}$ do reagente ADNS. A mistura foi aquecida em água fervente por $10 \mathrm{~min}$, e após resfriamento a temperatura ambiente a solução foi diluída em 10 volumes de água, para volume final de $4 \mathrm{~mL}$. As medidas foram feitas em um espectrofotômetro UV-Vis (Jasco V630) no comprimento de onda de $540 \mathrm{~nm}$.

\subsubsection{Principais mono e dissacarídeos solúveis na goiaba}

\subsubsection{Extração}

Os açúcares foram extraídos em água na proporção de $2 \mathrm{~g}$ de fruta triturada para $40 \mathrm{~g}$ de água e a mistura foi homogeneizada por $30 \mathrm{~min}$ em agitador magnético. As soluções foram filtradas em papel de filtro e em seguida em filtro de porosidade $0,45 \mu \mathrm{m}$, e analisadas em seguida pela técnica de eletroforese capilar (JAGER, TONIN e TAVARES, 2007). 


\subsubsection{Separação, identificação e quantificação}

As análises foram realizadas em um equipamento de eletroforese capilar P/ACE MDQ CE (Beckman-Coulter) com detecção por arranjo diodos, segundo adaptação do método descrito por Rovio, Yli-Kauhaluoma e Sirén, (2007).

Soluções estoque dos padrões de glicose, frutose e sacarose foram preparadas em água deionizada em sistema Milli-Q na concentração de $5 \mathrm{mg} \mathrm{mL}^{-1}$, e armazenadas sob refrigeração por no máximo 1 semana. A partir de diluições das soluções estoque foram construídas curvas analíticas para os açúcares na faixa de concentração entre 0,05 e $0,55 \mathrm{mg}$ $\mathrm{mL}^{-1}$.

As condições de separação foram as seguintes:

- capilar de sílica fundida com $75 \mu \mathrm{m}$ de diâmetro interno, $57 \mathrm{~cm}$ de comprimento total e $50 \mathrm{~cm}$ de comprimento efetivo;

- polaridade normal e injeção hidrodinâmica, por aplicação de 0,5 psi durante $3 \mathrm{~s}$, seguida por injeção do eletrólito de corrida por $3 \mathrm{~s}$;

- detecção direta com monitoramento em $270 \mathrm{~nm}$;

- eletrólito de separação $130 \mathrm{mmol} \mathrm{L}^{-1} \mathrm{NaOH}$ e 36 mmol L ${ }^{-1} \mathrm{Na}_{2} \mathrm{HPO}_{4} \cdot 2 \mathrm{H}_{2} \mathrm{O}$, pH 12,8;

- temperatura do capilar de $15^{\circ} \mathrm{C}$ e potencial de separação de $14 \mathrm{kV}$.

Para condicionamento do capilar todas as lavagens foram feitas aplicando-se uma pressão de 20 psi. O capilar foi condicionado antes de cada amostra com $\mathrm{NaOH} 1 \mathrm{~mol} \mathrm{~L}^{-1}$ por $15 \mathrm{~min}, \mathrm{NaOH} 0,1 \mathrm{~mol} \mathrm{~L}^{-1}$ por $5 \mathrm{~min}$, água deionizada durante 5 min e o eletrólito de corrida por $10 \mathrm{~min}$. Entre cada replicata utilizou-se $\mathrm{NaOH} 0,1 \mathrm{~mol} \mathrm{~L}^{-1}$ por $5 \mathrm{~min}$, água deionizada durante 2 min e o eletrólito de corrida por $5 \mathrm{~min}$.

Para estabelecimento das melhores condições de análise utilizou-se uma solução padrão com a mistura dos açúcares na concentração de $0,1 \mathrm{mg} \mathrm{mL}^{-1}$. Foram determinadas repetibilidade em um mesmo dia, repetibilidade entre dias, limite de detecção e limite de quantificação do método. 


\subsubsection{Pectinas}

\subsubsection{Extração}

Dez gramas de goiaba processada foram lavadas 3 vezes com água para retirada dos açúcares solúveis e ácidos orgânicos, centrifugada e levada a estufa a $60{ }^{\circ} \mathrm{C}$ por $6 \mathrm{~h}$. Em seguida foi triturada em almofariz e armazenada em frasco fechado a temperatura ambiente.

A extração da pectina foi realizada em meio ácido, segundo modificações do método descrito por Munhoz, Sanjinez-Argandoña e Soares-Júniro, (2008). Adicionou-se $100 \mathrm{ml}$ de água deionizada a $5 \mathrm{~g}$ da goiaba desidratada, mantendo sob agitação até a fervura. Em seguida adicionou-se $100 \mathrm{~mL}$ de solução $100 \mathrm{mmol} \mathrm{L}^{-1}$ de ácido cítrico e levado à fervura, completando um total de $200 \mathrm{~mL}$, o qual foi deixado sob aquecimento por $1 \mathrm{~h}$. Após esse procedimento, a solução foi resfriada em banho-maria a $4{ }^{\circ} \mathrm{C}$ por $2 \mathrm{~h}$ e filtrada em tecido de poliéster, desprezando o sobrenadante. Ao filtrado, foi adicionada uma solução de etanol 95\%, na proporção 2:1 (v:v), e deixada em repouso a temperatura ambiente por $2 \mathrm{~h}$. Ao final a solução foi filtrada, e o sobrenadante contendo a pectina foi deixado a temperatura ambiente para secar.

\subsubsection{Rendimento da extração}

O rendimento da extração foi determinado com base na diferença entre a massa seca inicial de goiaba e a massa final obtida após a extração ácida.

\subsubsection{Caracterização dos açúcares neutros presentes na pectina}

\subsection{Hidrólise}

Para caracterização dos açúcares neutros foi necessário realizar a hidrólise da pectina. Foi utilizado o método de acordo com Santos et al. (2010) com algumas modificações, no qual $1 \mathrm{~mL}$ de ácido trifluoracético (TFA) $2 \mathrm{~mol} \mathrm{~L}^{-1}$ foi adicionado a $5 \mathrm{mg}$ da pectina em atmosfera de nitrogênio e deixado por 10 horas a $100{ }^{\circ} \mathrm{C}$. Em seguida a solução foi centrifugada e o precipitado foi lavado uma vez com água e 3 vezes com metanol para total 
retirada do ácido. A amostra foi levada a secura e ressuspendida em água para análise por eletroforese capilar

\subsection{Separação, identificação e quantificação}

Assim como para os açúcares solúveis na goiaba as análises de açucares neutros foram realizadas em um equipamento de eletroforese capilar P/ACE MDQ CE (Beckaman-Coulter) com detecção por arranjo diodos, segundo adaptação do método descrito por Rovio, YliKauhaluoma e Sirén, (2007).

Soluções estoque de padrões dos açúcares foram preparadas em água deionizada em sistema Milli-Q na concentração de $5 \mathrm{mg} \mathrm{mL}^{-1}$, e armazenadas sob refrigeração por no máximo 1 semana. A partir de diluições das soluções estoque foram construídas curvas analíticas para os açúcares na faixa de concentração entre 0,01 e $0,40 \mathrm{mg} \mathrm{mL}^{-1}$. Foram avaliadas linearidade, repetibilidade em um mesmo dia, repetibilidade entre dias e limites de detecção e quantificação. As condições de separação do método foram as mesmas que as utilizadas para a determinação dos açúcares livres.

\subsubsection{Determinação de ácido ascórbico, deidroascórbico e ácido ascórbico total}

\subsubsection{Extração}

A extração da vitamina C foi realizada segundo Liao et al. (2001), com algumas modificações. Foram preparadas duas soluções de extração:

- Solução 1: 1 mmol L ${ }^{-1}$ EDTA / 0,2 $\mathrm{mol} \mathrm{L}^{-1} \mathrm{~K}_{2} \mathrm{HPO}_{4} /$ 0,474 $\mathrm{mol} \mathrm{L}^{-1} \mathrm{H}_{3} \mathrm{PO}_{4}$, pH 2;

- Solução 2: 1 mmol L ${ }^{-1}$ EDTA / 2,0\% ácido oxálico

Foram homogeneizados $20 \mathrm{~g}$ do fruto com $20 \mathrm{~mL}$ de solução 1 por $1 \mathrm{~min}$. Em seguida adicionou-se $24 \mathrm{~mL}$ de solução $2 \mathrm{em} 6 \mathrm{~g}$ do homogeneizado, homogeneizando-a novamente e procedendo uma centrifugação a $30.000 \times \mathrm{g}, 4^{\circ} \mathrm{C}$ por $5 \mathrm{~min}$. O sobrenadante foi dividido em duas partes para determinação de L-AA $(\mathbf{1 A})$ e ácido ascórbico total $(\mathbf{2 A})$ por CE.

- 1A: $1 \mathrm{~mL}$ do sobrenadante foi diluído com solução 2 para $5 \mathrm{~mL}$;

- 2A: a 1,5 mL do sobrenadante foram adicionados $6 \mathrm{~mL}$ de solução de homocisteína $(0,8 \%)$ e a mistura incubada a temperatura ambiente por $15 \mathrm{~min}$. Em seguida $4,5 \mathrm{~mL}$ da solução anterior foram misturados com $0,5 \mathrm{~mL}$ de solução 2 . 


\subsubsection{Separação, identificação e quantificação}

As análises foram realizadas em um equipamento de eletroforese capilar P/ACE MDQ CE (Beckaman-Coulter) com detecção por arranjo diodos, segundo adaptação do método descrito por LIAO et al. (2001).

Uma solução estoque do padrão de ácido ascórbico em solução 2 foi preparada na concentração de $1 \mathrm{mg} \mathrm{mL}^{-1}$, armazenada sob refrigeração e protegida da luz, por no máximo 1 semana. A partir de diluições da solução estoque com solução 2 foi determinada a curva analítica para o ácido ascórbico na faixa de concentração entre 2 e $120 \mu \mathrm{g} \mathrm{mL}^{-1}$. Foram avaliadas linearidade, repetibilidade em um mesmo dia, repetibilidade entre dias, recuperação e limites de detecção e quantificação.

As condições de separação do método foram as seguintes:

- capilar de sílica fundida com $75 \mu \mathrm{m}$ de diâmetro interno, $57 \mathrm{~cm}$ de comprimento total e $50 \mathrm{~cm}$ de comprimento efetivo;

- polaridade normal e injeção hidrodinâmica, por aplicação de 0,5 psi durante $5 \mathrm{~s}$;

- detecção direta com monitoramento em $265 \mathrm{~nm}$;

- eletrólito de separação fosfato de sódio $20 \mathrm{mmol} \mathrm{L}^{-1}$, pH 8.0;

- temperatura do capilar de $25^{\circ} \mathrm{C}$ e potencial de separação de $14 \mathrm{kV}$.

Para condicionamento do capilar todas as lavagens foram feitas aplicando-se uma pressão de 20 psi, como segue: lavagem com NaOH $1 \mathrm{~mol} \mathrm{~L}^{-1}$ por $10 \mathrm{~min}, \mathrm{NaOH} 0,1 \mathrm{~mol} \mathrm{~L}^{-1}$ por 2 min, água Mili-Q por 1 min e eletrólito de corrida por 3 min. Entre as corridas o capilar foi lavado com o eletrólito por $10 \mathrm{~min}$.

\subsubsection{Carotenóides majoritários}

\subsubsection{Extração dos carotenóides}

A extração dos carotenoides foi realizada segundo o método descrito por RodriguezAmaya (1999), com algumas modificações. A homogeneização da polpa ocorreu imediatamente antes da extração, para evitar que danos mecânicos (incorporação de ar, luz e oxigênio) pudessem contribuir para a degradação dos carotenóides. 
Para extração, $15 \mathrm{~g}$ de goiaba triturada foi pesada em balança analítica e acondicionada em tubo Falcon recoberto com papel alumínio. Em seguida adicionou-se aos poucos $80 \mathrm{~mL}$ de acetona, procedendo-se a agitação em mixer e posterior filtração. $\mathrm{O}$ extrato foi transferido para funil de separação, particionado para éter de petróleo e lavado com água, sendo que a fase etérea foi armazenada. Ao extrato em éter de petróleo foi adicionado sulfato de sódio anidro para retirada de resíduos de água, em seguida levado ao rotoevaporador (30$35^{\circ} \mathrm{C}$ ) até a diminuição do volume, transferido para frasco âmbar e levado a secura com gás nitrogênio. Todas as amostras foram acondicionadas a $-20{ }^{\circ} \mathrm{C}$ até o momento das análises.

\subsubsection{Separação e identificação dos carotenóides por cromatografia líquida de alta eficiência (HPLC)}

As análises por HPLC foram realizadas em um equipamento com sistema de bombas binárias, alça de amostragem de $20 \mu \mathrm{L}$ e detecção por arranjo de diodos (DAD) (Shimadzu), sendo que o método utilizado foi adaptado do descrito por Souza et al., (2004), e Sentanin e Rodriguez-Amaya (2007) .

A separação foi realizada em uma coluna de fase reversa, C18 (ODS-2, $150 \times 4,6 \mathrm{~mm}$, $3 \mu \mathrm{m}$ d.p.) a temperatura ambiente. Uma varredura de 200 a $700 \mathrm{~nm}$ foi realizada e o monitoramento do betacaroteno e licopeno foi realizado no comprimento de onda de $450 \mathrm{e}$ $470 \mathrm{~nm}$ respectivamente.

Imediatamente antes das análises as amostras foram ressuspendidas em $2 \mathrm{~mL}$ de acetona e filtradas em unidade filtrante de 0,45 $\mu \mathrm{m}$ de porosidade. A fase móvel utilizada consistiu de metanol/acetato de etila/acetonitrila, na proporção de 1:1:8 (v/v/v). O tempo de equilíbrio da coluna foi de 20 min e a vazão da fase móvel de $1 \mathrm{~mL} \mathrm{~min}^{-1}$. As análises foram feitas no modo isocrático de eluição.

Para quantificação do beta-caroteno, uma solução estoque do padrão em acetona foi preparada na concentração de $200 \mu \mathrm{g} \mathrm{mL}^{-1}$, armazenada sob refrigeração e protegida da luz, por no máximo 1 semana, e diluída para determinação de uma curva analítica na faixa de concentração entre 80 e $800 \mu \mathrm{g} \mathrm{mL}^{-1}$. Foram avaliadas linearidade, repetibilidade em um mesmo dia, repetibilidade entre dias e limites de detecção e quantificação.

A identificação do beta-caroteno na amostra foi realizada pela comparação do seu tempo de eluíção com o do padrão e comportamento nas condições de análise comparado a literatura (SENTANIN e RODRIGUEZ-AMAYA, 2007; SOUZA et al., 2004), assim como, 
pelo seu espectro UV-vis característico obtido pelo detector de arranjo de diodo $\left(\lambda_{\text {máx }}\right)$ comparando com resultados encontrados na literatura (SENTANIN e RODRIGUEZAMAYA, 2007; SOUZA et al., 2004).

A determinação do licopeno foi realizada pela comparação do espectro com o encontrado na literatura e relação da posição do pico no cromatograma com encontrado na literatura para a mesma fase móvel. Devido à ausência de padrão para construção de curva de calibração e posterior quantificação, a caracterização do comportamento do licopeno com o desenvolvimento e em relação às adubações, foi realizada com base nas áreas obtidas para o pico respectivo determinado no cromatograma.

\subsection{Análise estatística e quimiométrica dos dados}

Foi realizado teste ANOVA dentro de cada variável estudada, no intuito de verificar diferença significativa entre as médias e comprovada a diferença, determinou-se qual ou quais fatores foram os responsáveis. Um teste ANOVA foi realizado em relação às coletas e outro em relação à adubação. Para a realização do teste, são calculados a variância dentro dos grupos e entre grupos. A razão entre essas variâncias fornece um fator $\mathrm{f}$ calculado, que quando maior que o tabelado, indica diferença significativa entre os valores.

Além da análise estatística, algumas variáveis foram relacionadas por análise quimiométrica. Para isso utilizou-se a ferramenta de Análise de Componentes Principais (PCA). Não foram analisadas por quimiometria a composição de açúcares neutros da pectina, assim como o perfil do licopeno com a maturação e adubação. O uso desta ferramenta teve como objetivo verificar a possibilidade de um padrão de agrupamento entre as goiabas coletadas nas diferentes épocas e goiabas provenientes das diferentes doses de adubação, além de, identificar as principais variáveis que influenciaram esse agrupamento.

Os dados foram dispostos em 16 linhas (correspondentes às amostras) e 15 colunas (correspondentes às variáveis). Os dados foram normalizados para que a presença de ruídos não afetasse negativamente a análise, e analisados pelo programa Minitab 16. 


\section{RESULTADOS E DISCUSSÃO}

\subsection{Coleta e armazenamento das amostras}

As amostras coletadas foram divididas em duas partes com 6 frutos cada uma. Uma das partes foi armazenada para análise de vitamina $\mathrm{C}$ e carotenóides, enquanto que a outra foi utilizada para caracterização física, em seguida triturada e imediatamente utilizada para realizar as análises físico-químicas. As amostras trituradas foram acondicionadas em sacos plásticos escuros e armazenadas a $-18{ }^{\circ} \mathrm{C}$ para posterior análise dos açúcares e pectina. Os resultados serão discutidos com base no perfil do desenvolvimento da fruta e com relação à adubação nitrogenada. Vale ressaltar que as fases de desenvolvimento estudadas foram do crescimento à maturação, atingindo a maturidade fisiológica, correspondente a última coleta.

\subsection{Caracterização do tamanho}

Diferentes parâmetros físicos estão ligados à aceitação do fruto pelos consumidores e/ou pela indústria, como por exemplo, cor, tamanho e formato. Sabe-se que com o desenvolvimento do fruto ocorre o aumento das células, e consequentemente, incremento de peso e tamanho (AZZOLINI, 2002). Como esperado, houve um aumento nos diâmetros transversal (DT) e longitudinal (DL) dos frutos avaliados, o que pode ser observado visualmente, assim como pelos resultados apresentados na Tabela 4. O aumento dos diâmetros dos frutos com o seu desenvolvimento foi observado para todas as adubações realizadas, como pode ser acompanhado pela Figura 4. 
Tabela 4 - Características físicas (média \pm desvio padrão) de diâmetro transversal (DT), diâmetro longitudinal (DL) e relação DL/DT durante o desenvolvimento dos frutos nas diferentes adubações $\left(\mathrm{N}_{0}=0 \mathrm{~g}\right.$ de $\mathrm{N} ; \mathrm{N}_{1}=500$ $\mathrm{g}$ de $\mathrm{N} ; \mathrm{N}_{2}=1000 \mathrm{~g}$ de $\mathrm{N} ; \mathrm{N}_{3}=2000 \mathrm{~g}$ de $\mathrm{N}$ ).

\begin{tabular}{|c|c|c|c|c|c|}
\hline & \multirow{2}{*}{ Coletas 2010} & \multicolumn{4}{|c|}{ Adubação } \\
\hline & & NO & N1 & N2 & N3 \\
\hline \multirow{4}{*}{$\begin{array}{c}\mathrm{DL} \\
(\mathrm{cm})\end{array}$} & Coleta 1 & $4,35^{\mathrm{aA}} \pm 0,34$ & $4,67^{\mathrm{aA}} \pm 0,23$ & $4,71^{\mathrm{aA}} \pm 0,60$ & $4,43^{\mathrm{aA}} \pm 0,59$ \\
\hline & Coleta 2 & $4,37^{\mathrm{aA}} \pm 0,15$ & $4,62^{\mathrm{aA}} \pm 0,38$ & $4,79^{\mathrm{bA}} \pm 0,37$ & $4,69^{\mathrm{aA}} \pm 0,22$ \\
\hline & Coleta 3 & $6,81^{\mathrm{aB}} \pm 0,59$ & $6,67^{\mathrm{aB}} \pm 0,15$ & $5,90^{\mathrm{bB}} \pm 0,29$ & $6,66^{\mathrm{aB}} \pm 0,75$ \\
\hline & Coleta 4 & $7,27^{\mathrm{aB}} \pm 0,88$ & $8,02^{\mathrm{aC}} \pm 0,71$ & $8,16^{\mathrm{ac}} \pm 0,77$ & $8,18^{\mathrm{ac}} \pm 0,67$ \\
\hline \multirow{4}{*}{$\begin{array}{c}\text { DT } \\
(\mathrm{cm})\end{array}$} & Coleta 1 & $3,58^{\mathrm{aA}} \pm 0,18$ & $3,61^{\mathrm{aA}} \pm 0,22$ & $3,55^{\mathrm{aA}} \pm 0,10$ & $3,63^{\mathrm{aA}} \pm 0,21$ \\
\hline & Coleta 2 & $3,69^{\mathrm{aA}} \pm 0,15$ & $3,67^{\mathrm{aA}} \pm 0,20$ & $3,83^{\mathrm{aB}} \pm 0,30$ & $3,75^{\mathrm{aA}} \pm 0,38$ \\
\hline & Coleta 3 & $5,18^{\mathrm{aB}} \pm 0,42$ & $5,03^{\mathrm{abB}} \pm 0,37$ & $4,73^{b c} \pm 0,23$ & $5,29^{a B} \pm 0,46$ \\
\hline & Coleta 4 & $7,35^{\mathrm{ac}} \pm 0,83$ & $7,08^{\mathrm{ac}} \pm 0,34$ & $7,13^{\mathrm{aD}} \pm 0,31$ & $7,13^{\mathrm{ac}} \pm 0,35$ \\
\hline \multirow{4}{*}{ DL/DT } & Coleta 1 & $1,22^{\mathrm{aAB}} \pm 0,07$ & $1,29^{\mathrm{aA}} \pm 0,06$ & $1,33^{\mathrm{aA}} \pm 0,17$ & $1,22^{\mathrm{aA}} \pm 0,15$ \\
\hline & Coleta 2 & $1,19^{a A} \pm 0,08$ & $1,26^{\mathrm{aA}} \pm 0,06$ & $1,26^{\mathrm{aA}} \pm 0,09$ & $1,26^{\mathrm{aA}} \pm 0,08$ \\
\hline & Coleta 3 & $1,31^{\mathrm{aB}} \pm 0,11$ & $1,33^{\mathrm{aA}} \pm 0,09$ & $1,25^{\mathrm{aA}} \pm 0,05$ & $1,26^{\mathrm{aA}} \pm 0,10$ \\
\hline & Coleta 4 & $0,99^{a} c_{ \pm 0,13}$ & $1,13^{\mathrm{aB}} \pm 0,07$ & $1,14^{\mathrm{aA}} \pm 0,06$ & $1,15^{\mathrm{aA}} \pm 0,13$ \\
\hline
\end{tabular}

Médias seguidas pela mesma letra ( $\mathrm{a}$ e b) na linha não diferem entre si em relação à adubação pelo teste ANOVA, com 95\% de significância $(0,05)$. Médias seguidas pela mesma letra $(\mathrm{A}, \mathrm{B}, \mathrm{C}$ e $\mathrm{D})$ na coluna não diferem entre si em relação ao estádio de desenvolvimento pelo teste ANOVA, com $95 \%$ de significância $(0,05)$.

Os frutos maduros apresentaram diâmetro transversal entre 7,08 e 7,35 cm e diâmetro longitudinal na faixa de 7,27 e 8,18 cm, para as diferentes adubações, sendo maiores que os observados para goiabas da mesma variedade provenientes do semiárido da Paraíba, os quais não ultrapassaram 6,48 e 7,25 para diâmetro transversal e longitudinal, respectivamente (GOUVEIA et al., 2004). Valores de diâmetro transversal de $6,28 \mathrm{~cm}$ e longitudinal de 7,10 $\mathrm{cm}$ para os frutos maduros foram observados por Gouveia et al., (2003) e outro trabalho relata diâmetro transversal de 5,57 cm e diâmetro longitudinal 6,29 cm (LIMA, ASSIS e NETO, 2002). 
Figura 4 - Perfil do diâmetro (a) transversal e (b) longitudinal com o desenvolvimento dos frutos para todas as adubações $\left(\mathrm{N}_{0}=0 \mathrm{~g}\right.$ de $\mathrm{N} ; \mathrm{N}_{1}=500 \mathrm{~g}$ de $\mathrm{N} ; \mathrm{N}_{2}=1000 \mathrm{~g}$ de $\mathrm{N} ; \mathrm{N}_{3}=2000 \mathrm{~g}$ de $\left.\mathrm{N}\right)$.

(a)

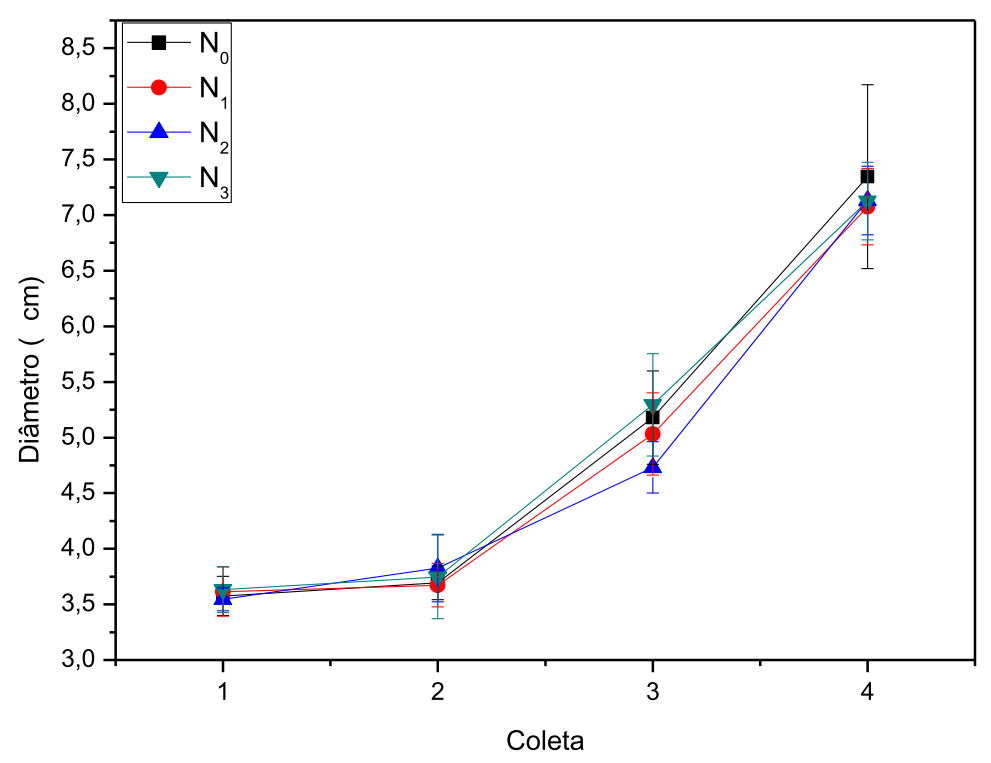

(b)

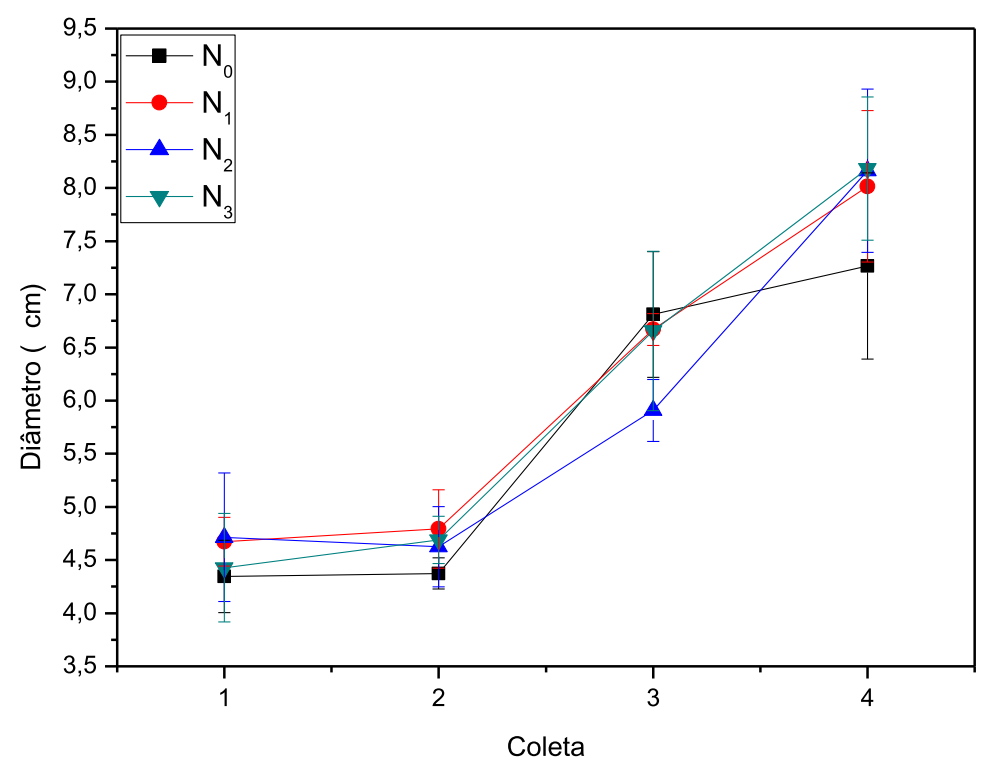

A variação de DL e DT entre a primeira e segunda coleta não foram significativas. No entanto, a variação das duas primeiras coletas (frutos ainda verdes) com cada uma das duas últimas demonstraram variação significativa de tamanho.

Relacionando o diâmetro longitudinal com a adubação, foi observada uma variação significativa apenas na segunda coleta, na qual a adubação $\mathrm{N}_{2}$ provocou um aumento principalmente em relação a adubação $\mathrm{N}_{0}$, e na terceira coleta, na qual a adubação $\mathrm{N}_{2}$ provocou uma diminuição de DL. Na primeira e última coleta a adubação não influenciou significativamente os valores de DL. Em relação a DT, apenas a terceira coleta apresentou 
variações significativas com a adubação, dividindo em dois grupos, no qual $\mathrm{N}_{0}$ e $\mathrm{N}_{3}$ não diferem entre si, mas diferem de $\mathrm{N}_{1}$ e $\mathrm{N}_{2}$.

Nos frutos maduros o aumento da adubação nitrogenada levou a um ligeiro aumento do diâmetro longitudinal das goiabas, no entanto essa variação não foi significativa. $O$ aumento de DL também foi observado em um trabalho realizado por Medeiros et al., (2004), sendo que os mesmos observaram uma diminuição no diâmetro transversal, o que não foi observado nesse trabalho. No entanto, considerando os valores absolutos eles não observaram diferenças significativas estatisticamente. Nenhuma variação significativa dos diâmetros em goiabas da cv. Paluma foi observada em um trabalho realizado por Gouveia et al., (2004).

Em geral os frutos para processamento industrial devem possuir tamanho médio, enquanto que para o consumo in natura de médio a grande (GOUVEIA et al., 2004). Contudo, de acordo com os resultados obtidos a variação da dose de adubação nitrogenada não proporcionou efeito significativo nas dimensões da fruta, sendo que mesmo na ausência da adubação nitrogenada $\left(\mathrm{N}_{0}\right)$ elas apresentaram tamanho adequado para comercialização.

A análise da relação DL/DT é bastante representativa na caracterização dos genótipos de goiabeiras, uma vez que esta relação indica o formato do fruto, que quanto mais próximo de 1 mais redondo (GERHARDT et al., 1997). Gerhardt et al., (1997) observaram que diferentes cultivares apresentaram diferentes valores da relação DL/DT como RBS-1 $(1,32)$ e RBS-2 (1,23) que apresentam formato alongado, Pirassununga Vermelha $(1,11)$, Brune Vermelha $(1,10)$ e Riverside Vermelha $(1,09)$, mais arredondadas, e a IAC-4 $(0,98)$ e Patillo $(0,96)$, com formato redondo e até um pouco achatado. Os autores destacam que a altitude onde são cultivadas pode influenciar suas dimensões (GERHARDT et al., 1997), além da ausência ou não de irrigação, épocas e intensidade das podas (SERRANO et al., 2008).

Como pode ser observado na Figura 5, com o desenvolvimento do fruto a tendência da relação DL/DT foi a aproximação de 1, ou seja, os frutos partiram de um formato mais alongado para mais arredondados quando maduros. Esse perfil foi observado para todas as variações de adubação. Em geral, para todas as adubações a terceira coleta apresentou maiores valores de DL/DT, o que significa que nesse estágio houve uma maior diferença entre as dimensões da fruta, sendo que na coleta posterior os valores de DL e DT se apresentaram mais próximos. 
Figura 5 - Relação DL/DT em relação ao desenvolvimento para todas as diferentes adubações $\left(\mathrm{N}_{0}=0 \mathrm{~g}\right.$ de $\mathrm{N} ; \mathrm{N}_{1}$ $=500 \mathrm{~g}$ de $\mathrm{N} ; \mathrm{N}_{2}=1000 \mathrm{~g}$ de $\mathrm{N} ; \mathrm{N}_{3}=2000 \mathrm{~g}$ de $\mathrm{N}$ ).

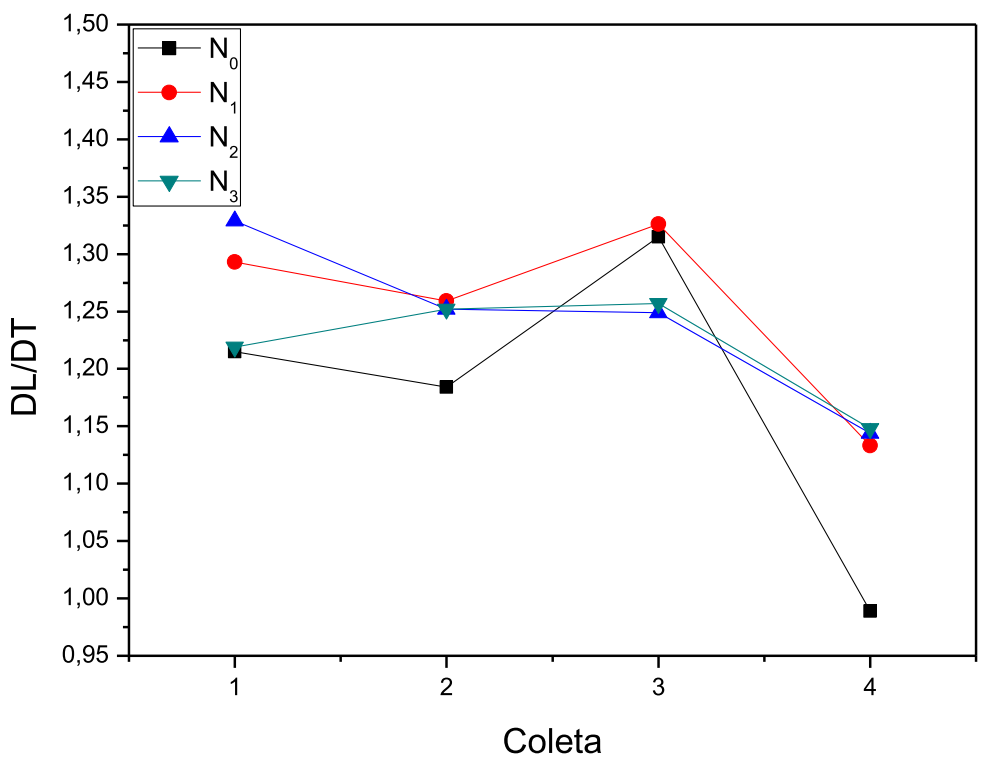

Os frutos sem adubação nitrogenada $\left(\mathrm{N}_{0}\right)$ apresentaram valores mais próximos de $1 \mathrm{em}$ relação as demais adubações, chegando a 0,99 no fruto maduro, caracterizando formato redondo. Contudo, com base na análise estatística realizada, pode-se concluir que o aumento da adubação nitrogenada não proporcionou variação significativa nos valores de DL/DT. Além disso, pode-se observar que os valores encontrados caracterizando frutos alongados (valores superiores a 1) estão de acordo com os encontrados por outros autores para a mesma cultivar (LIMA, ASSIS e NETO, 2002; SERRANO et al., 2008).

\subsection{Caracterização Química}

\subsubsection{Determinação do pH}

Observou-se uma diminuição do $\mathrm{pH}$ com o desenvolvimento do fruto, variando de 6,22 a 3,83 (Fig. 6), fato contrário ao observado no trabalho de Sinuco et al., (2010), que relataram um aumento do $\mathrm{pH}$ com o amadurecimento da goiaba vermelha proveniente da Colômbia, cultivar conhecida como Regional Roja, variando de 3,80 para 4,16. Gouveia et al., (2003), analisando goiaba cv. Paluma proveniente da região da Paraíba, também observaram aumento do $\mathrm{pH}$ dos frutos, que variou entre 3,82 a 4,40 no período entre 157 a 171 dias após início da frutificação. Vale ressaltar que nesses trabalhos a variação do $\mathrm{pH}$ foi monitorada durante a fase da maturação, já na maturidade fisiológica, enquanto que no nosso trabalho 
essa variação foi monitorada desde os primeiros estágios de desenvolvimento, com as goiabas verdes e pequenas. $\mathrm{O}$ mesmo comportamento foi observado para todas as adubações, como apresentado na Figura 6.

Figura 6 - Variação do pH em relação ao desenvolvimento para as diferentes adubações $\left(\mathrm{N}_{0}=0 \mathrm{~g}\right.$ de $\mathrm{N} ; \mathrm{N}_{1}=500$ g de $\mathrm{N} ; \mathrm{N}_{2}=1000 \mathrm{~g}$ de $\mathrm{N} ; \mathrm{N}_{3}=2000 \mathrm{~g}$ de $\left.\mathrm{N}\right)$.

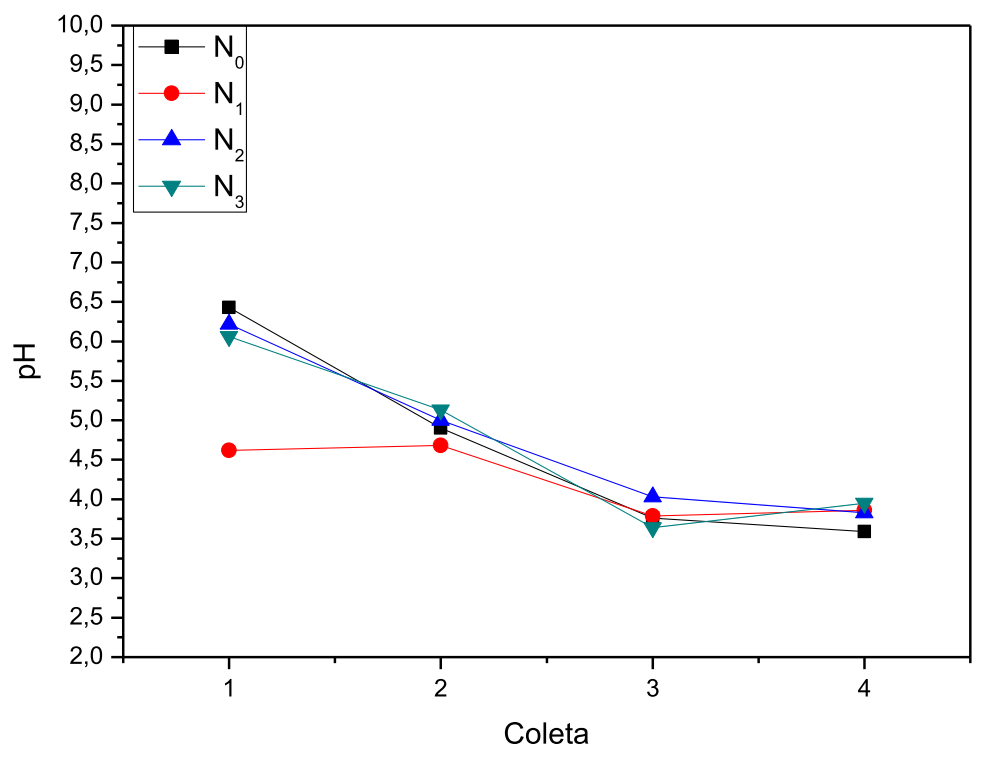

Todos os valores de $\mathrm{pH}$ diferiram significativamente segundo o teste ANOVA com 95\% de significância $(0,05)$, tanto com relação às coletas como às adubações. Na goiaba verde a adubação $\mathrm{N}_{1}$ apresentou $\mathrm{pH}$ menor que as demais. Já na goiaba madura o $\mathrm{pH}$ foi menor na ausência de adubação nitrogenada. Não foi observada variação significativa de $\mathrm{pH}$ para cv. Paluma do semiárido da Paraíba (GOUVEIA et al., 2004) com diferentes doses da adubação nitrogenada, assim como para frutos do mamoeiro (Marinho et al., 2001).

$\mathrm{O}$ pH encontrado para as amostras maduras (coleta 4) variou entre 3,59 e 3,94 para adubação $\mathrm{N}_{0}$ e $\mathrm{N}_{3}$ respectivamente, valores próximos ao encontrado por Gouveia et al., (2004) em goiabas provenientes do semiárido da Paraíba, que variou entre 3,90 e 3,92. Segundo Manica et al., (1998), valores de pH superiores a 3,5 indicam a necessidade de se adicionar ácidos orgânicos comestíveis no processamento dos frutos, visando a uma melhor qualidade do produto final. De acordo com os resultados obtidos, o aumento da adubação nitrogenada favorece a necessidade da adição desses ácidos durante o processamento da goiaba, procedimento esse que pode elevar o custo do produto final, não sendo interessante para a indústria processadora. 


\subsection{2 Índice de polifenóis totais (IPT)}

Os polifenóis constituem um grupo numeroso de moléculas, entre elas os flavonóides e ácidos fenólicos. Esses compostos podem desempenhar funções diferentes nas plantas, dentre elas fotoproteção e defesa contra patógenos, além de conferir algumas características organolépticas aos alimentos e agirem como antioxidantes (KUSKOSKI et al., 2002).

Para quatro cultivares diferentes de goiaba provenientes do Sudão alguns autores observaram uma diminuição do teor de polifenóis com o desenvolvimento do fruto (EL BULK, BABIKER e EL TINAY, 1997). Entretanto, para goiabas da cv. Kumagai cultivadas no Brasil não foi observada variação comparando dois estádios de desenvolvimento (frutos verdes e frutos maduros) (MORGADO et al., 2010).

Foram encontradas algumas dificuldades na determinação do índice de polifenóis totais para todas as coletas e adubações avaliadas devido a dificuldades de extrair o suco da polpa ainda verde (coleta 1 e 2). Na coleta 2 foi possível determinar apenas para a adubação $\mathrm{N}_{2}$, porém, nas coletas seguintes todas as amostras foram analisadas.

Como pode ser visto na Figura 7, ao contrário do observado por El Bulk, Babiker e El Tinay, (1997), com o desenvolvimento dos frutos houve um aumento do IPT, com exceção das amostras provenientes da adubação $\mathrm{N}_{1}$.

Figura 7- Variação do IPT em relação ao desenvolvimento para todas as adubações $\left(\mathrm{N}_{0}=0 \mathrm{~g}\right.$ de $\mathrm{N} ; \mathrm{N}_{1}=500 \mathrm{~g}$ de $\mathrm{N} ; \mathrm{N}_{2}=1000 \mathrm{~g}$ de $\mathrm{N} ; \mathrm{N}_{3}=2000 \mathrm{~g}$ de $\left.\mathrm{N}\right)$.

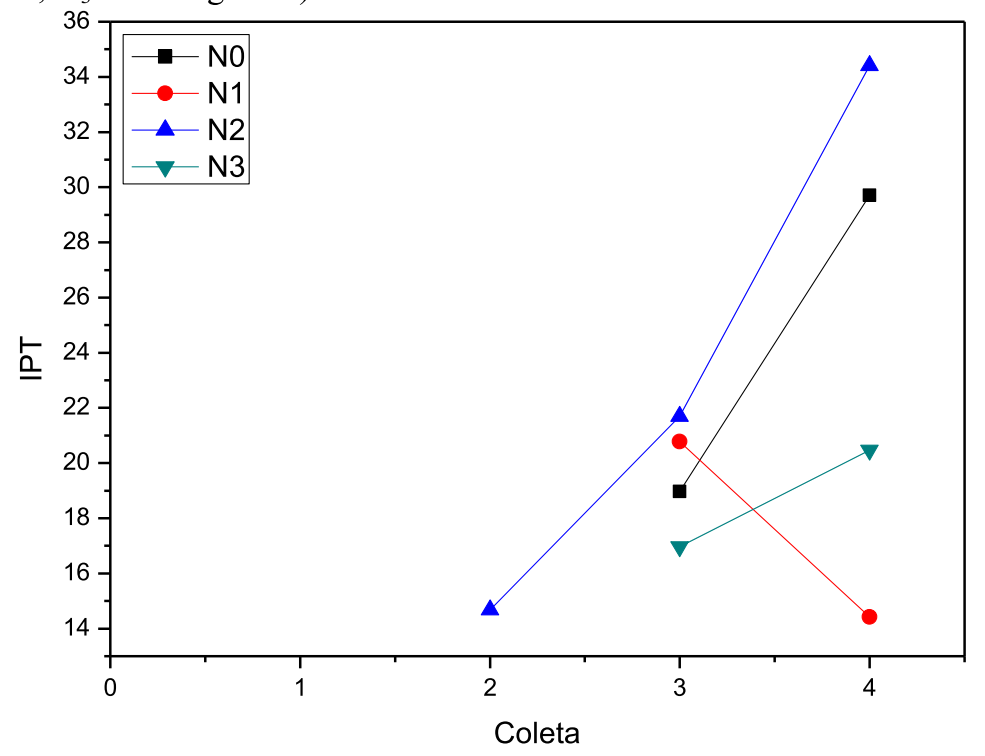

Com já foi dito, apenas na coleta 3 e 4 foi possível determinar o IPT nas amostras provenientes de todas as adubações. Na coleta 3 houve um ligeiro aumento do IPT com o 
aumento da adubação nitrogenada, seguida por um decréscimo quando adubada com a máxima dose. Já na goiaba madura (coleta 4), a adubação $\mathrm{N}_{2}$ apresentou o maior IPT em relação as demais.

Segundo o teste ANOVA, com 95\% de significância $(0,05)$, as variações entre os diferentes estádios de desenvolvimento e as diferentes doses de adubação nitrogenada foram estatisticamente significativas. Não foi encontrada na literatura a relação de polifenóis totais com a dose de adubação nitrogenada, mas observou-se que uma elevada dose de nitrogênio causa diminuição da concentração total destes compostos.

\subsubsection{Acidez total titulável (ATT)}

Os ácidos orgânicos, entre eles ascórbico, málico, cítrico e lático (CHAN, BREKKE e CHANG, 1971; WILSON, SHAW e CAMPBELL, 1982), são os principais responsáveis pela acidez do fruto da goiaba. Com o amadurecimento eles tendem a diminuir, pois representam os principais substratos para os processos respiratórios durante o amadurecimento (AZZOLINI, JACOMINO e BRON, 2004). A Figura 8 apresenta a variação de ATT com o desenvolvimento dos frutos para as diferentes adubações.

Figura 8 - Variação da ATT em relação ao desenvolvimento para todas as adubações $\left(\mathrm{N}_{0}=0 \mathrm{~g}\right.$ de $\mathrm{N} ; \mathrm{N}_{1}=500 \mathrm{~g}$ de $\mathrm{N} ; \mathrm{N}_{2}=1000 \mathrm{~g}$ de $\mathrm{N} ; \mathrm{N}_{3}=2000 \mathrm{~g}$ de $\mathrm{N}$ ).

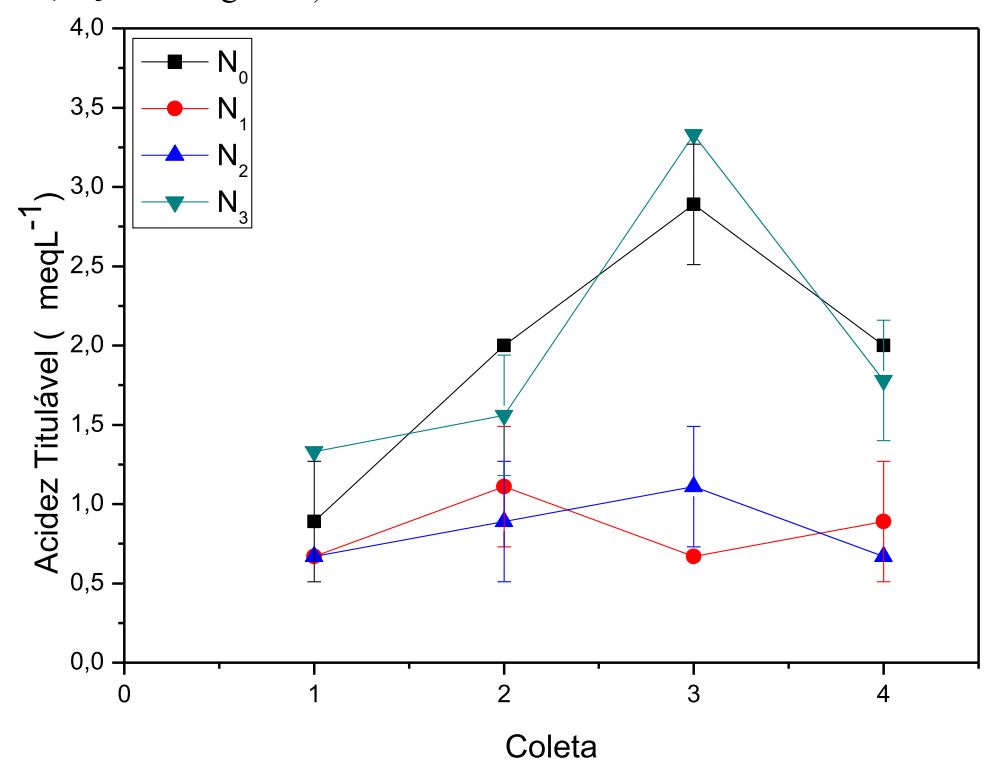

É possível observar que com exceção das amostras provenientes da adubação $\mathrm{N}_{1}$, há um aumento de ATT até a terceira coleta, seguida por uma diminuição na fruta madura. A 
variação entre os diferentes estádios de desenvolvimento não foram significativas para as adubações $\mathrm{N}_{1}$ e $\mathrm{N}_{2}$ segundo teste ANOVA, com 95\% de significância $(0,05)$. Essa diminuição da acidez titulável na goiaba madura em relação a coleta anterior pode ser explicada pelo fato de que nos últimos estágios do desenvolvimento, na maturação, ocorre um aumento do teor de açúcar paralelamente a degradação de ácidos orgânicos (GOUVEIA et al., 2003). No entanto a variação entre os diferentes estádios de desenvolvimento não foram significativas para as adubações $\mathrm{N}_{1}$ e $\mathrm{N}_{2}$ segundo teste ANOVA, com $95 \%$ de significância $(0,05)$.

Em relação ao desenvolvimento da fruta (fases de crescimento e maturação até a maturidade fisiológica), foi observado para a goiaba Media China um aumento da acidez em relação a goiaba verde (inicio de desenvolvimento) e goiaba madura (MERCADO-SILVA, BENITO-BAUTISTA e GARCÍA-VELASC, 1998).

Para a fase de maturação (fase que compreende mudanças bioquímicas, fisiológicas e estruturais), alguns trabalhos observaram uma diminuição na acidez titulável, como a cv. Paluma proveniente do vale de São Francisco, na qual foi observada uma diminuição de 0,86 para $0,49 \%$ de ácido cítrico (LIMA et al., 2008). Para cv. Paluma proveniente do estado da Paraíba também observou-se uma diminuição da acidez titulável, de 0,89 para 0,63\% (GOUVEIA et al., 2003), assim como para a cv. Pedro Sato, na qual a variação da acidez em relação a goiaba verde e madura, foi de $0,60 \%$ para 0,51\% (AZZOLINI, JACOMINO e BRON, 2004). No entanto, a cv. Regional Roja cultivada na Colômbia não apresentou diferenças significativas em relação à acidez total titulável entre os diferentes estádios de maturação (SINUCO et al., 2010).

Em relação à adubação com doses crescentes de nitrogênio, pode-se ver que as adubações $\mathrm{N}_{1}$ e $\mathrm{N}_{2}$ foram as que apresentaram menores valores, enquanto que goiabas adubadas com $\mathrm{N}_{3}$ e sem adubação nitrogenada apresentaram valores maiores.

O aumento da acidez titulável com a adubação nitrogenada foi observado em goiaba cv. Paluma do semiárido da Paraíba, a qual variou de $0,74 \%$ a $0,86 \%$, o que não foi significativo estatisticamente (GOUVEIA et al., 2004), assim como em mamoeiros, nos quais não foram observadas mudanças significativas na acidez com o aumento da dose de nitrogênio na adubação (MARINHO et al., 2001).

De acordo com o teste ANOVA com 95\% de significância, na primeira coleta a variação foi significativa apenas na adubação $\mathrm{N}_{3}$ em relação às demais. Já em relação às duas coletas intermediárias, as adubações $\mathrm{N}_{1}$ e $\mathrm{N}_{2}$ não diferiram significativamente entre si, porém diferiram das adubações $\mathrm{N}_{0}$ e $\mathrm{N}_{3}$, que também foram diferentes entre si. Na goiaba madura 
formaram-se dois grupos, sendo que $\mathrm{N}_{1}$ e $\mathrm{N}_{2}$ não diferiram entre si, mais diferiram de $\mathrm{N}_{0}$ e $\mathrm{N}_{3}$ que não são diferentes significativamente, sendo que doses intermediárias de adubação proporcionaram menores teores de acidez titulável, concordando com Gouveia et al, (2003), que ressaltam que doses crescentes de nitrogênio podem causar aumento da acidez.

\subsubsection{Sólidos solúveis totais $(\mathrm{SST}) \mathrm{-}^{\circ} \mathrm{BRIX}$}

Os açúcares são os principais responsáveis pelo teor de sólidos solúveis, seguido pelos ácidos orgânicos, sendo a frutose o principal açúcar encontrado na goiaba (AZZOLINI, JACOMINO e BRON, 2004).

Para determinação do ${ }^{\circ}$ Brix foi utilizado o suco obtido pela maceração das amostras. No entanto, para as amostras ainda verdes (coleta 1 e coleta 2 ) não foi possível extrair suco suficiente para leitura. Apenas a amostra $\mathrm{N}_{2}$ da coleta 2 apresentou quantidade considerável para determinação do ${ }^{\circ}$ Brix. Os valores obtidos para as amostras analisadas são apresentados na Tabela 5 .

Tabela 5 - SST ( ${ }^{\circ}$ Brix) (média \pm desvio padrão) durante o desenvolvimento nas diferentes adubações $\left(\mathrm{N}_{0}=0 \mathrm{~g}\right.$ de $\mathrm{N} ; \mathrm{N}_{1}=500 \mathrm{~g}$ de $\mathrm{N} ; \mathrm{N}_{2}=1000 \mathrm{~g}$ de $\mathrm{N} ; \mathrm{N}_{3}=2000 \mathrm{~g}$ de $\mathrm{N}$ ).

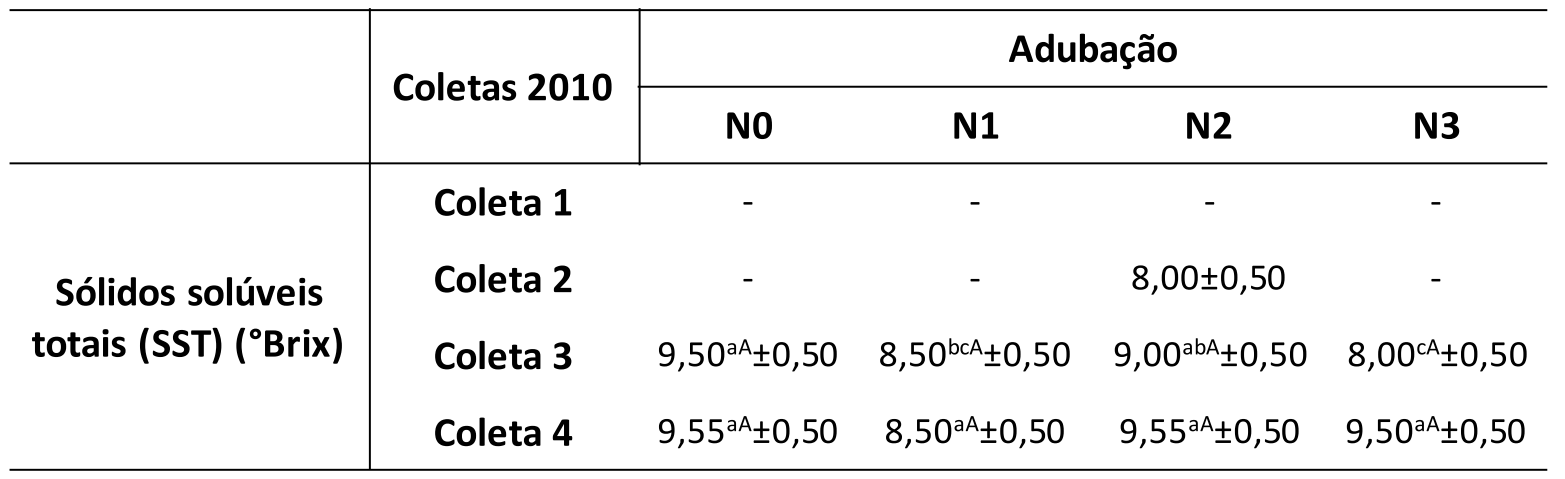

Médias seguidas pela mesma letra $(\mathrm{a}, \mathrm{b}$ e c) na linha não diferem entre si em relação à adubação pelo teste ANOVA, com 95\% de significância $(0,05)$. Médias seguidas pela mesma letra (A e B) na coluna não difere entre si em relação ao estádio de desenvolvimento pelo teste ANOVA, com 95\% de significância $(0,05)$.

Durante a fase de maturação ocorre a síntese dos açúcares, além da degradação do amido (SINUCO et al., 2010), e consequentemente aumento dos sólidos solúveis totais, o que pode ser observado desde a primeira fase do desenvolvimento dos frutos (Figura 9). Com exceção da amostra proveniente da adubação $\mathrm{N}_{1}$, que não apresentou diferença entre os dois estádios estudados, todas as demais adubações apresentaram um aumento dos sólidos solúveis com o desenvolvimento do fruto. 
Figura 9 - Variação do teor de SST ( ${ }^{\circ}$ Brix) em relação ao desenvolvimento para todas as adubações $\left(\mathrm{N}_{0}=0 \mathrm{~g}\right.$ de $\mathrm{N} ; \mathrm{N}_{1}=500 \mathrm{~g}$ de $\mathrm{N} ; \mathrm{N}_{2}=1000 \mathrm{~g}$ de $\mathrm{N} ; \mathrm{N}_{3}=2000 \mathrm{~g}$ de $\left.\mathrm{N}\right)$.

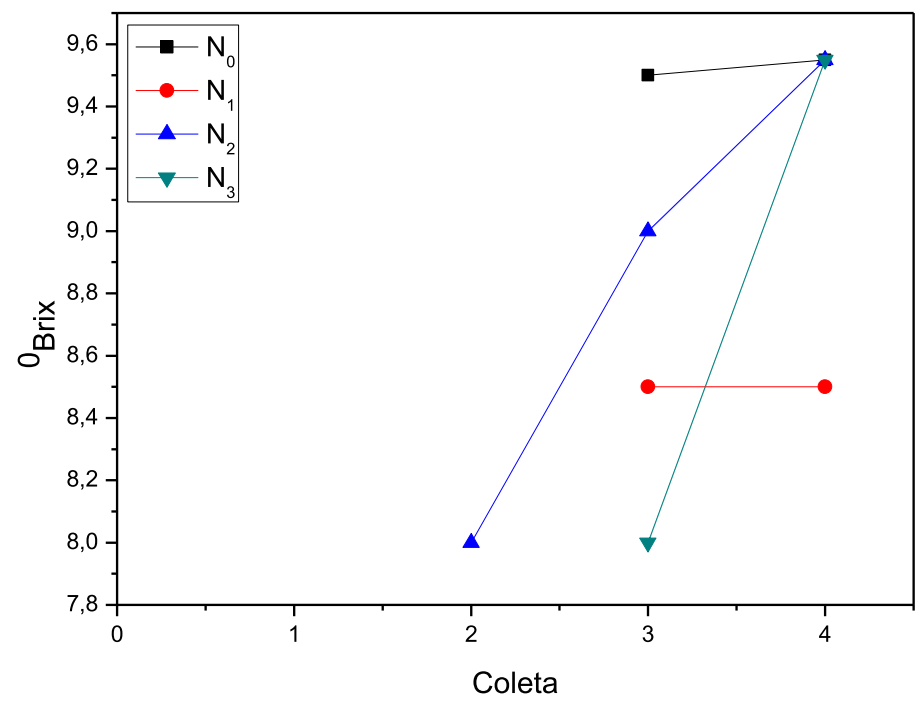

Em vários trabalhos observou-se um aumento do teor de SST com a maturação. Lima et al., (2008) avaliaram a goiaba Paluma proveniente do Vale de São Francisco, na qual observou-se um aumento considerável dos SST apenas no fruto maduro em relação aos estádios anteriores de desenvolvimento, sendo que os intermediários não diferenciaram significativamente entre si. Este comportamento também foi observado para a cv. Pedro Sato, na qual o SST variou de 6,90 ${ }^{\circ}$ Brix na goiaba verde para 7,60 ${ }^{\circ}$ Brix na madura (AZZOLINI, JACOMINO e BRON, 2004). No trabalho de SINUCO et al., (2010) com a goiaba vermelha Regional Roja, os valores variaram entra 9,80 e 10,5 ${ }^{\circ}$ Brix. Também foi observado um aumento dos sólidos solúveis em quatro diferentes cultivares de goiabas do Sudão (EL BULK, BABIKER e EL TINAY, 1997).

Em relação à adubação, na coleta $3, \mathrm{~N}_{0}$ apresentou maior valor de ${ }^{\circ}$ Brix em relação as demais adubações. No entanto entre as amostras adubadas, $\mathrm{N}_{2}$ teve um aumento em relação à adubação $\mathrm{N}_{1}$ e $\mathrm{N}_{3}$. Já na goiaba madura (coleta 4) foi possível observar uma pequena diminuição do ${ }^{\circ}$ Brix com adubação $\mathrm{N}_{1}$ em relação as demais, no entanto não houve variação significativa.

Em goiabas cv. Paluma adubadas com nitrogênio no semiárido da Paraíba não foram observados valores de ${ }^{\circ}$ Brix superiores a 5,8\% (GOUVEIA et al., 2004). Diferentemente, em outro trabalho com cv. Paluma adubada com doses crescentes de nitrogênio foram observados valores de ${ }^{\circ}$ Brix entre 8,4 e 9,6\%, não apresentando diferença significativa em relação à variação da adubação (NATALE et al., 1995). 
Outras frutas, como o mamão, por exemplo, não apresentaram variação significativa do teor de SST com o aumento da dose de adubação nitrogenada (MARINHO et al., 2001), sendo que o contrário foi observado em laranjas, no qual o aumento da dose de adubação nitrogenada acarretou no aumentou do teor de SST no suco (ALMEIDA e BAUMGARTNER, 2002).

Altos valores de sólidos solúveis são desejáveis tanto para o consumo in natura quanto para industrialização, tornando a goiaba atrativa principalmente para fabricação de geléias (SINUCO et al., 2010). Com base nos resultados obtidos, podemos concluir que o aumento da adubação nitrogenada não proporciona melhora nesse atributo, sendo assim, não é interessante para sua comercialização.

\subsubsection{Relação SST/ATT}

Segundo Gerhardt et al. (1997), altos valores da relação SST/ATT podem contribuir para alta qualidade organoléptica dos frutos. Como pode ser visto na Figura 10, esta relação aumentou com o desenvolvimento da fruta, exceto para a adubação $\mathrm{N}_{1}$. Maiores valores da relação SST/ATT nas goiabas maduras eram esperados, pois é nesse estágio que a fruta fica passível de ser consumida.

Figura 10 - Relação SST/ATT em relação ao desenvolvimento para todas as adubações $\left(\mathrm{N}_{0}=0 \mathrm{~g}\right.$ de $\mathrm{N} ; \mathrm{N}_{1}=500$ g de $\mathrm{N} ; \mathrm{N}_{2}=1000 \mathrm{~g}$ de $\mathrm{N} ; \mathrm{N}_{3}=2000 \mathrm{~g}$ de $\left.\mathrm{N}\right)$.

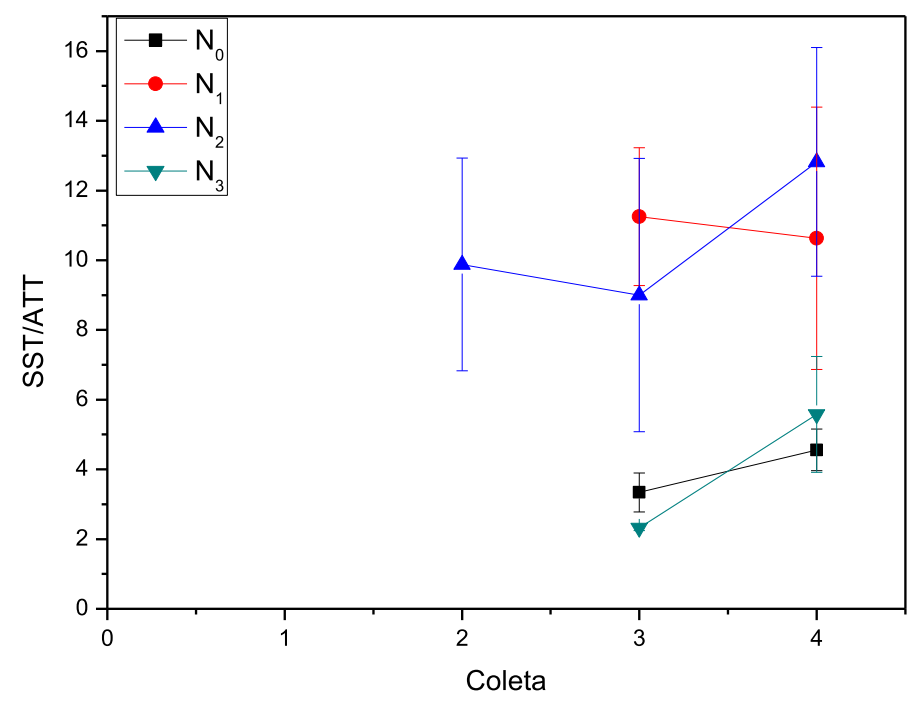

Com o desenvolvimento do fruto, os valores de SST/ATT variaram de 2,32 $\left(\mathrm{C}_{3}-\mathrm{N}_{3}\right)$ a $12,8\left(\mathrm{C}_{4}-\mathrm{N}_{2}\right)$. De acordo com outros trabalhos, dentro do período de maturação também foi 
observado um aumento desta relação, variando de 9,88 a 17,66 (CAVALINI et al., 2006) e 4,34 e 12,60 (GOUVEIA et al., 2003), ambos valores encontrados para cultivar Paluma. Para goiabas Pedro Sato os valores variaram entre 11,60 e 15,10 (AZZOLINI et al., 2004), variação menor que a encontrada para a cultivar Paluma, no entanto com maior relação SST/ATT.

O maior valor encontrado para goiaba madura neste trabalho foi de 12,8 para adubação $\mathrm{N}_{2}$, valor abaixo dos 17,63 encontrados por Lima, Assis e Neto (2002) e dos 17,66 relatados por Cavalini et al., (2006). Porém encontrou-se próximo do valor descrito por Gouveia et al., (2003), 12,60, para a mesma cultivar.

Em relação à adubação é possível observar que as adubações $\mathrm{N}_{0}$ e $\mathrm{N}_{3}$ proporcionaram menores valores para SST/ATT. Ainda que tenha havido uma queda com o desenvolvimento para as amostras $\mathrm{N}_{1}$, o valor obtido ainda é superior às adubações $\mathrm{N}_{0}$ e $\mathrm{N}_{3}$. Segundo Gouveia et al., (2003) o aumento da adubação nitrogenada pode causar aumento na acidez, com isso a relação SST/ATT torna-se menor. No entanto, pelos resultados obtidos pode-se concluir que a ausência da adubação nitrogenada possui o mesmo efeito, sendo que $\mathrm{N}_{2}$ foi a adubação que apresentou maiores resultados.

\subsubsection{Açúcares redutores totais}

Para determinação dos açúcares redutores pelo método do ADNS foi necessária a construção de uma curva de calibração com a glicose (Fig.11).

Figura 11 - Curva de calibração analítica para glicose.

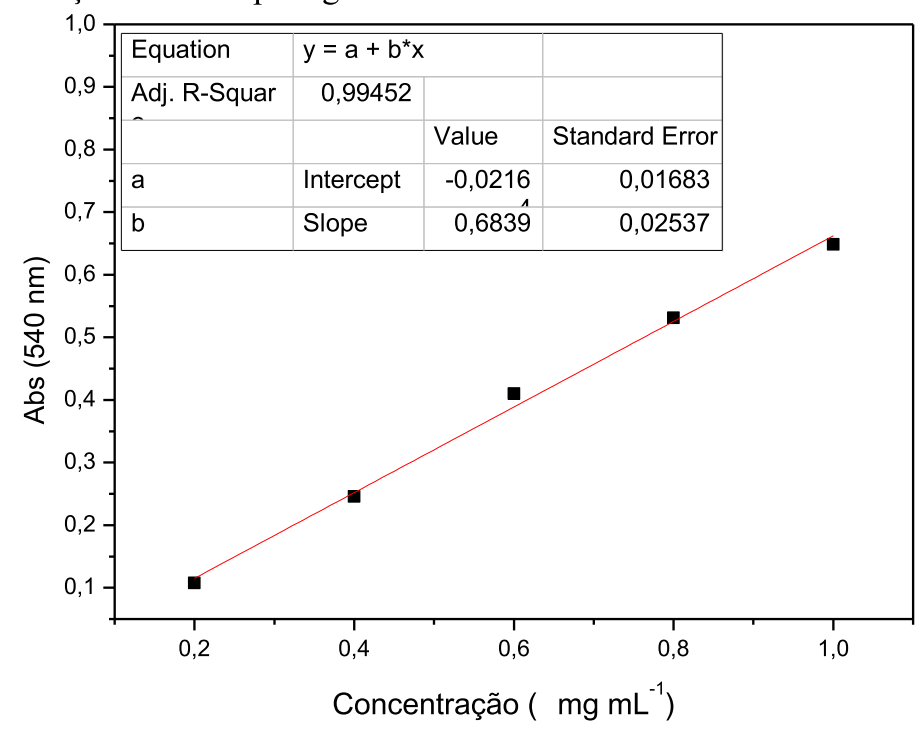


$\mathrm{Na}$ Tabela 6 são apresentados os valores encontrados para os açúcares redutores nas amostras avaliadas.

Tabela 6 - Açúcares redutores totais (média \pm desvio padrão) durante o desenvolvimento nas diferentes adubações $\left(\mathrm{N}_{0}=0 \mathrm{~g}\right.$ de $\mathrm{N} ; \mathrm{N}_{1}=500 \mathrm{~g}$ de N; $\mathrm{N}_{2}=1000 \mathrm{~g}$ de N; $\mathrm{N}_{3}=2000 \mathrm{~g}$ de N$)$.

\begin{tabular}{c|c|cccc}
\hline \multirow{2}{*}{} & \multirow{2}{*}{ Coleta } & \multicolumn{4}{|c}{ Adubação } \\
\cline { 3 - 6 } & & N0 & N1 & N2 & N3 \\
\hline \multirow{3}{*}{$\begin{array}{c}\text { Açúcares } \\
\text { Redutores }\end{array}$} & Coleta 1 & $794,39^{\mathrm{aA}} \pm 0,01$ & $1044,13^{\mathrm{bA}} \pm 0,01$ & $734,14^{\mathrm{cA}} \pm 0,01$ & $849,66^{\mathrm{dA}} \pm 0,01$ \\
(mg 100 $\left.^{-1}\right)$ & Coleta 2 & $1307,33^{\mathrm{ab}} \pm 0,01$ & $1385,99^{\mathrm{bB}} \pm 0,01$ & $1610,88^{\mathrm{cB}} \pm 0,01$ & $1571,98^{\mathrm{dB}} \pm 0,01$ \\
& Coleta 3 & $3334,64^{\mathrm{aC}} \pm 0,01$ & $4806,55^{\mathrm{bC}} \pm 0,01$ & $5680,13^{\mathrm{cC}} \pm 0,01$ & $4139,06^{\mathrm{dC}} \pm 0,01$ \\
& Coleta 4 & $3331,72^{\mathrm{aD}} \pm 0,01$ & $5101,92^{\mathrm{bD}} \pm 0,01$ & $3366,81^{\mathrm{cD}} \pm 0,01$ & $3463,31^{\mathrm{dD} \pm 0,01}$ \\
\hline
\end{tabular}

Médias seguidas pela mesma letra (a e b) na linha não diferem entre si em relação à adubação pelo teste ANOVA, com $95 \%$ de significância $(0,05)$. Médias seguidas pela mesma letra (A, B, C e D) na coluna não diferem entre si em relação ao estádio de desenvolvimento pelo teste ANOVA, com $95 \%$ de significância $(0,05)$.

Foi possível observar um aumento dos açúcares redutores com o desenvolvimento dos frutos até a terceira coleta, seguido por um decréscimo na fruta completamente madura, com exceção da adubação $\mathrm{N}_{1}$, que apresentou concentração de açúcares redutores crescente até a goiaba madura (Figura 12). Na goiaba cv. Banarsi Surkha cultivadas em na Índia foi observado um aumento dos açúcares redutores (glicose e frutose) com a maturação (JAIN, et al., 2003).

Figura 12 - Variação dos açúcares redutores totais com o desenvolvimento para todas as adubações $\left(\mathrm{N}_{0}=0 \mathrm{~g}\right.$ de $\mathrm{N} ; \mathrm{N}_{1}=500 \mathrm{~g}$ de $\mathrm{N} ; \mathrm{N}_{2}=1000 \mathrm{~g}$ de $\mathrm{N} ; \mathrm{N}_{3}=2000 \mathrm{~g}$ de N).

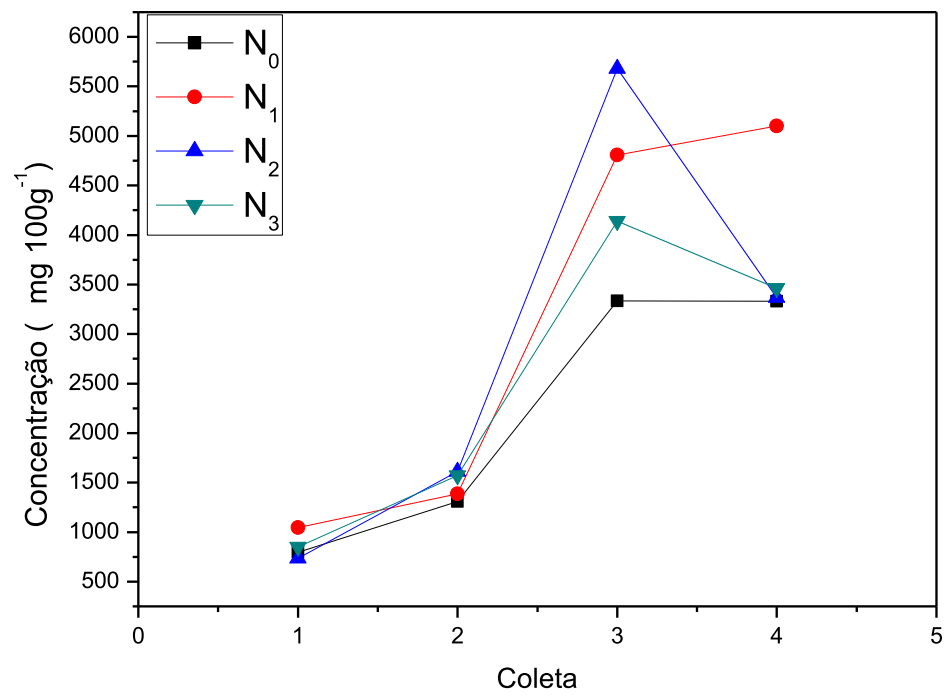


Tanto as variações em relação ao desenvolvimento do fruto quanto em relação à adubação foram significativas, segundo teste ANOVA, com $95 \%$ de significância $(0,05)$. Com a variação da dose de adubação nitrogenada pode-se observar que para cada coleta as amostras se comportaram de forma distinta. Na primeira e segunda coleta (goiabas ainda verdes), a adubação influenciou muito pouco a concentração de açúcares redutores. Já na terceira coleta a adubação $\mathrm{N}_{2}$ se destacou em relação ao teor de açúcares redutores, sendo que as demais adubações apresentaram valores menores. Já na goiaba totalmente madura a adubação $\mathrm{N}_{1}$ proporcionou maiores valores de açúcares redutores para a amostra. Não foi encontrado na literatura referências sobre a influência da adubação nitrogenada nos açúcares redutores.

Os açúcares redutores assim como os ácidos orgânicos, estão diretamente relacionados com os sólidos solúveis totais. As amostras sem adubação nitrogenada $\left(\mathrm{N}_{0}\right)$ apresentaram menor aumento dos SST entre as duas últimas coletas, diminuição da acidez titulável e ligeira diminuição dos açúcares redutores. Já as adubações $\mathrm{N}_{2}$ e $\mathrm{N}_{3}$ apresentaram grande aumento dos SST, no entanto diminuição de ATT assim como dos açúcares redutores, o que nos leva a pensar que além desses outros compostos podem estar relacionados com o aumento do teor de SST.

\subsubsection{Principais mono e dissacarídeos livres na goiaba (sacarose, glicose e frutose)}

A determinação de sacarose, glicose e frutose foi otimizada por eletroforese capilar com detecção por arranjo de diodos, seguindo o método de Rovio et al., (2008), com algumas adaptações. Utilizando uma mistura de padrões, preparou-se uma curva analítica para cada um dos açúcares estudados, e a Tabela 7 apresenta os resultados obtidos, juntamente com os limites de detecção e de quantificação do método. 
Tabela 7 - Equações de regressão linear, coeficientes de correlação, limites de detecção e quantificação e faixa de concentração estudada para cada um dos açúcares analisados.

\begin{tabular}{|c|c|c|c|c|c|}
\hline Açúcares & $\begin{array}{c}\text { Equaçãa da reta } \\
\mathbf{Y}=\mathbf{A}+\mathbf{B X}\end{array}$ & $\begin{array}{c}\text { Coeficiente } \\
\text { de correlação }\end{array}$ & $\begin{array}{c}\text { LD } \\
\left(\mathbf{m g ~ m L ^ { - 1 }}\right)\end{array}$ & 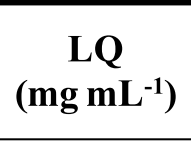 & $\begin{array}{c}\text { Faixa } \\
\text { estudada } \\
\left(\mathrm{mg} \mathrm{mL}^{-1}\right)\end{array}$ \\
\hline Sacarose & $Y=-30142,37+6,214 * 10^{5} X$ & 0,988 & 0,034 & 0,114 & $0,05-0,35$ \\
\hline Glicose & $Y=-62454,12+8,005 * 10^{5} \mathrm{X}$ & 0,997 & 0,026 & 0,087 & $0,1-0,55$ \\
\hline Frutose & $\mathrm{Y}=-12843,83+3,179 * 10^{5} \mathrm{X}$ & 0,998 & 0,023 & 0,075 & $0,05-0,55$ \\
\hline
\end{tabular}

$\mathrm{LD}=\frac{\mathrm{DPa} \times 3}{\mathrm{IC}} ; \mathrm{LQ}=\frac{\mathrm{DPa} \times 10}{\mathrm{IC}}$

Os coeficientes de correlação entre a concentração de cada açúcar e sua área de pico variaram entre 0,988 e 0,998 para a sacarose e frutose, respectivamente. Para determinação dos limites de detecção e quantificação foi utilizado o método descrito pela ANVISA, que considera, respectivamente, a razão entre três e dez vezes o desvio padrão dos interceptos das curvas analíticas $\left(\mathrm{DP}_{\mathrm{a}}\right.$ ) e as inclinações (IC) das mesmas (ANVISA, 2003).

$\mathrm{Na}$ Tabela 8 é possível observar os resultados dos coeficientes de variação (CV\%) para tempo de migração e área de pico, determinados pela precisão do método quanto à sua repetibilidade (intra-dia) e precisão intermediária (entre-dias). Para repetibilidade, seis injeções consecutivas foram feitas durante um mesmo dia. A precisão intermediária foi determinada pela análise de três injeções consecutivas, durante três dias.

Tabela 8 - Precisão do método para análises intra-dia e entre-dias.

\begin{tabular}{c|cc|cc}
\hline \multirow{2}{*}{ Açúcares } & \multicolumn{2}{|c|}{ Repetibilidade $(\mathbf{n}=\mathbf{6})$} & \multicolumn{2}{c}{$\begin{array}{c}\text { Precisão Intermediária } \\
(\mathbf{n}=\mathbf{9}) *\end{array}$} \\
\cline { 2 - 5 } & $\begin{array}{c}\mathrm{CV}(\%) \\
\text { tempo de migração }\end{array}$ & $\begin{array}{c}\mathrm{CV}(\%) \\
\text { área depico }\end{array}$ & $\begin{array}{c}\mathrm{CV}(\%) \\
\text { tempo de migração }\end{array}$ & $\begin{array}{c}\mathrm{CV}(\%) \\
\text { área de pico }\end{array}$ \\
\hline Sacarose & 1,38 & 3,00 & 3,38 & 14,00 \\
Glicose & 1,50 & 4,00 & 1,16 & 16,00 \\
Frutose & 1,54 & 9,00 & 1,27 & 24,00 \\
\hline
\end{tabular}

$\mathrm{CV} \%=(\mathrm{DP} /$ média $) \times 100$

* três injeções consecutivas por 3 dias não consecutivos 
Os valores de CV (\%) para repetibilidade não ultrapassaram 1,54\% para o tempo de migração, sendo que para área de pico a frutose apresentou até 9,00\%. Para precisão entredias os valores de CV (\%) para o tempo de migração não ultrapassaram 3,38\%, enquanto que mais uma vez os valores obtidos para área de pico foram altos, ficando entre 14,00 e 24,00\% para sacarose e frutose, respectivamente. Rovio et al. (2008), atribuem a baixa repetibilidade à degradação química dos açúcares na presença da solução com $\mathrm{pH}$ fortemente básico. Em solução alcalina, condição utilizada neste trabalho para análise dos carboidratos, estes podem participar de uma série de reações de ionização, mutarrotação, enolização e isomerização, resultando em um ânion enediolato. O enediolato é intermediário da reação de degradação dos carboidratos, que produz ácidos orgânicos. No entanto, a presença do cátion sódio em solução previne que a reação prossiga para degradação, estabilizando o ânion enediolato.

Após a otimização do método de separação dos açúcares realizou-se a extração das amostras em todas as 4 coletas e 4 diferentes adubações, e foram realizadas as análise de eletroforese capilar. Na Figura 13 pode-se observar os eletroferogramas referentes à amostra $\mathrm{N}_{2}$ e a mistura dos padrões.

Figura 13 - Eletroferogramas referente (a) à amostra $\mathrm{N}_{2}$ e (b) à mistura de padrões.

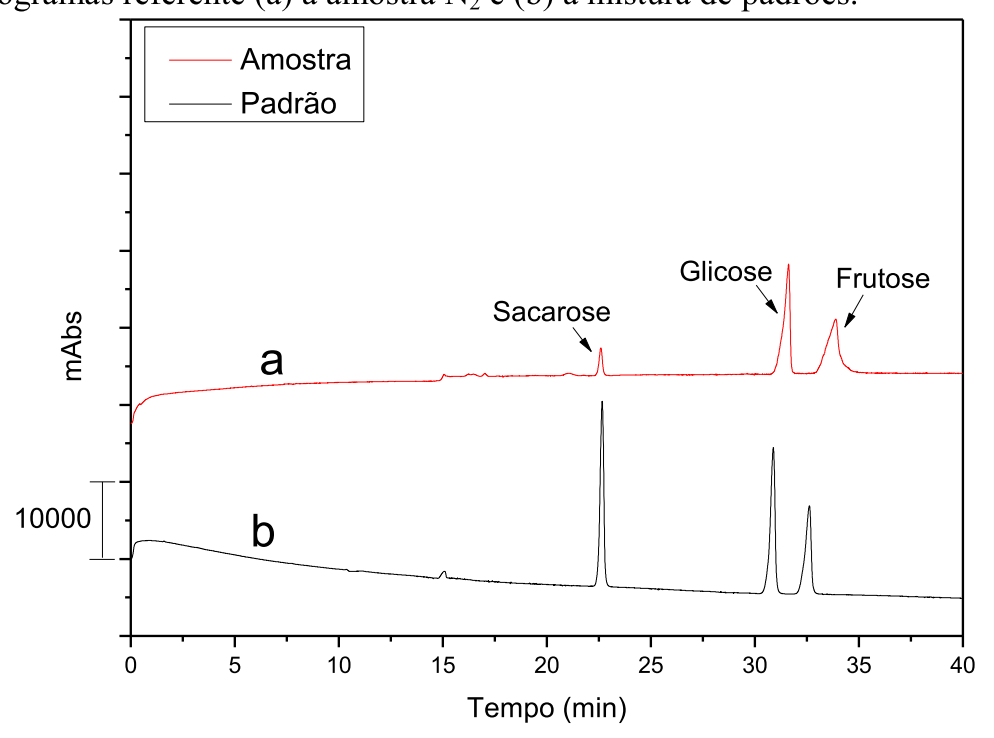

A partir das curvas analíticas obtidas determinou-se a concentração de cada açúcar em cada amostra, sendo os valores encontrados apresentados na Tabela 9.

Segundo Gouveia et al., (2003) à medida que o fruto se desenvolve, assim como durante a fase da maturação, ocorre um aumento no seu teor de açúcar total. Pelos resultados apresentados para cada açúcar individualmente é possível observar que, em geral, há o 
aumento dos açúcares redutores (glicose e futose), de acordo com o que foi observado para os teores de açúcares redutores totais, e diminuição da sacarose com a maturação.

Tabela 9 - Concentração dos açúcares solúveis presentes na goiaba (média \pm desvio padrão) durante $o$ desenvolvimento nas diferentes adubações $\left(\mathrm{N}_{0}=0 \mathrm{~g}\right.$ de N; $\mathrm{N}_{1}=500 \mathrm{~g}$ de N; $\mathrm{N}_{2}=1000 \mathrm{~g}$ de N; $\mathrm{N}_{3}=2000 \mathrm{~g}$ de $\mathrm{N})$.

\begin{tabular}{|c|c|c|c|c|c|}
\hline & \multirow{2}{*}{ Coletas 2010} & \multicolumn{4}{|c|}{ Adubação } \\
\hline & & No & N1 & $\mathbf{N} 2$ & N3 \\
\hline \multirow{4}{*}{$\begin{array}{c}\text { Sacarose } \\
\left(\mathrm{mg} \mathrm{100g}^{-1}\right)\end{array}$} & Coleta 1 & $194,82^{\mathrm{aA}} \pm 16,29$ & $153,09^{\mathrm{bA}} \pm 7,33$ & $109,11^{\mathrm{cA}} \pm 6,67$ & $214,68^{\mathrm{dA}} \pm 10,44$ \\
\hline & Coleta 2 & $261,03^{\mathrm{aA}} \pm 92,67$ & $86,66^{\mathrm{bB}} \pm 0,76$ & $135,59^{\mathrm{bcA}} \pm 0,82$ & $179,96^{\mathrm{acAB}} \pm 53,94$ \\
\hline & Coleta 3 & $68,66^{\mathrm{aB}} \pm 7,92$ & $20,61^{\mathrm{bC}} \pm 0,86$ & $51,99^{a C} C_{ \pm 11,32}$ & $135,67^{\mathrm{cB}} \pm 24,68$ \\
\hline & Coleta 4 & $83,22^{\mathrm{aB}} \pm 4,59$ & $\mathrm{ND}^{\mathrm{bD}}$ & $274,79^{\mathrm{cD}} \pm 46,59$ & $260,86^{\mathrm{cA}} \pm 43,37$ \\
\hline \multirow{4}{*}{$\begin{array}{c}\text { Glicose } \\
\left(\mathrm{mg} \mathrm{100g}^{-1}\right)\end{array}$} & Coleta 1 & $161,76^{\mathrm{aA}} \pm 11,19$ & $231,91^{\mathrm{bA}} \pm 22,99$ & $183,62^{\mathrm{abA}} \pm 17,16$ & $259,68^{\mathrm{cA}} \pm 12,61$ \\
\hline & Coleta 2 & $528,68^{\mathrm{aA}} \pm 216,19$ & $240,35^{\mathrm{bA}} \pm 7,34$ & $190,26^{\mathrm{bB}} \pm 4,14$ & $130,13^{\mathrm{bA}} \pm 4,84$ \\
\hline & Coleta 3 & $792,83^{a B} \pm 393,39$ & $162,93^{\mathrm{bA}} \pm 36,10$ & $3180,00^{\circ} \pm 273,90$ & $887,79^{\mathrm{aB}} \pm 547,71$ \\
\hline & Coleta 4 & $1137,00^{\mathrm{aB}} \pm 277,28$ & $2831,49^{\mathrm{b}} \mathrm{B}_{ \pm} 770,92$ & $2856,70^{\mathrm{bC}} \pm 953,87$ & $1451,23^{x} \pm 142,63$ \\
\hline \multirow{4}{*}{$\begin{array}{c}\text { Frutose } \\
\left(\mathrm{mg} \mathrm{100g}^{-1}\right)\end{array}$} & Coleta 1 & $207,03^{\mathrm{abA}} \pm 18,47$ & $190,74^{\mathrm{aA}} \pm 6,96$ & $215,24^{\mathrm{bA}} \pm 11,27$ & $344,46^{\mathrm{cA}} \pm 16,84$ \\
\hline & Coleta 2 & $605,03^{\mathrm{aAB}} \pm 232,34$ & $295,63^{\mathrm{bA}} \pm 3,00$ & $247,89^{\mathrm{bA}} \pm 9,65$ & $175,72^{\mathrm{bA}} \pm 24,28$ \\
\hline & Coleta 3 & $790,01^{\mathrm{aB}} \pm 490,66$ & $417,95^{\mathrm{aA}} \pm 305,46$ & $2906,25^{\mathrm{bB}} \pm 223,29$ & $853,54^{\mathrm{aB}} \pm 377,37$ \\
\hline & Coleta 4 & $993,99^{\mathrm{B}} \pm 289,04$ & $2659,28^{\mathrm{aB}_{ \pm}} 1391,15$ & $2672,73^{a \mathrm{~B}} \pm 1391,15$ & $1109,53^{\mathrm{aB}} \pm 306,94$ \\
\hline
\end{tabular}

Médias seguidas pela mesma letra $(\mathrm{a}, \mathrm{b}, \mathrm{c}$ e d) na linha não diferem entre si em relação à adubação pelo teste ANOVA, com $95 \%$ de significância $(0,05)$. Médias seguidas pela mesma letra $(\mathrm{A}, \mathrm{B}, \mathrm{C}$ e D) na coluna não difere entre si em relação aos estádios de desenvolvimento pelo teste ANOVA, com $95 \%$ de significância $(0,05)$.

Na Figura 14 pode-se observar o comportamento da concentração de cada açúcar com o desenvolvimento da goiaba para as diferentes adubações. 
Figura 14 - Variação dos açúcares com o desenvolvimento nas quatro diferentes adubações: (a) $\mathrm{N}_{0}$; (b) $\mathrm{N}_{1}$; (c) $\mathrm{N}_{2}$; (d) $\mathrm{N}_{3}$.

(a)

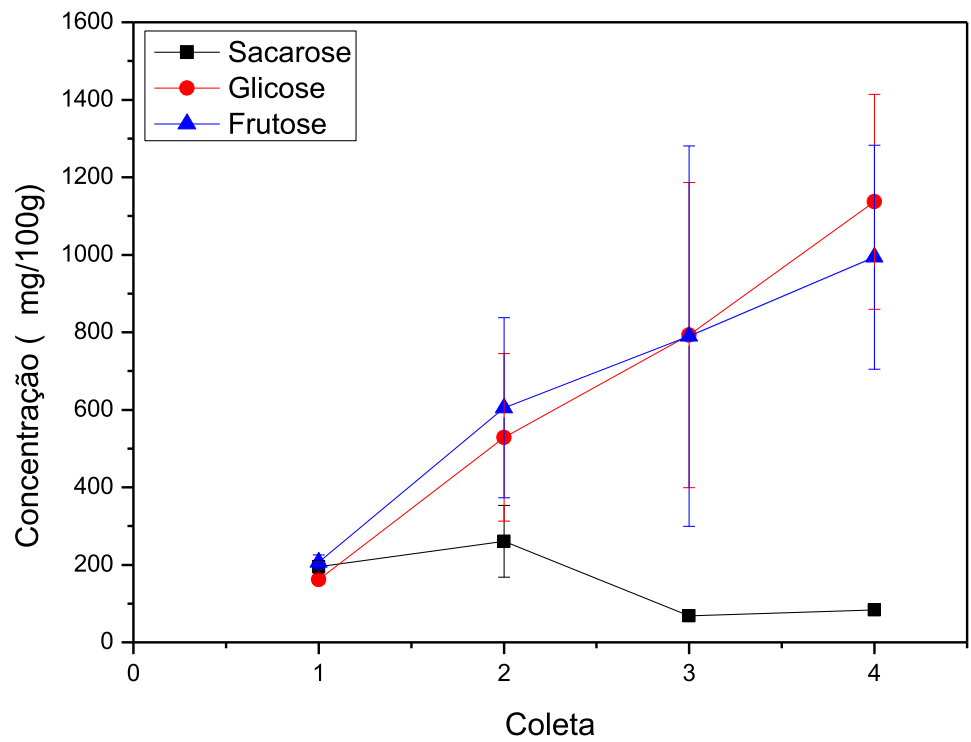

(b)

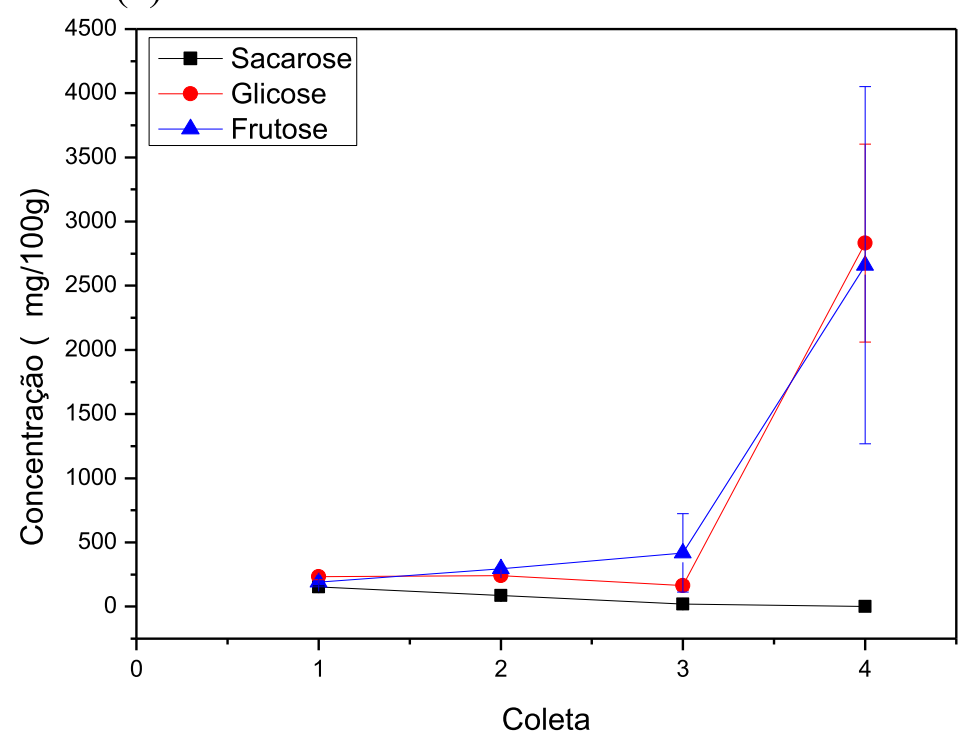


c)

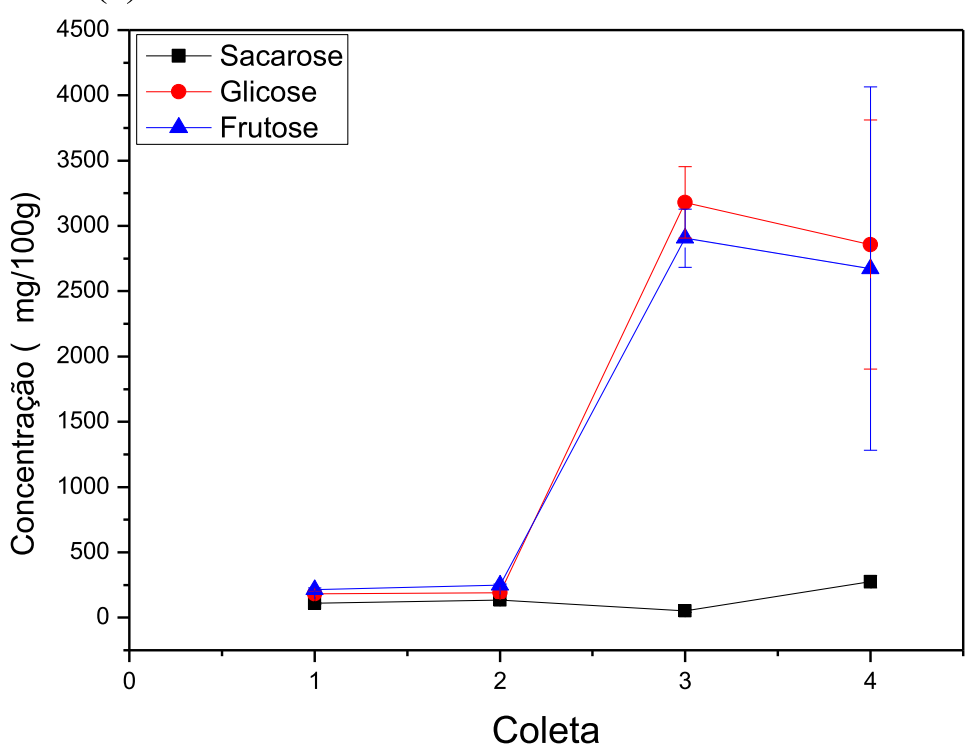

(d)

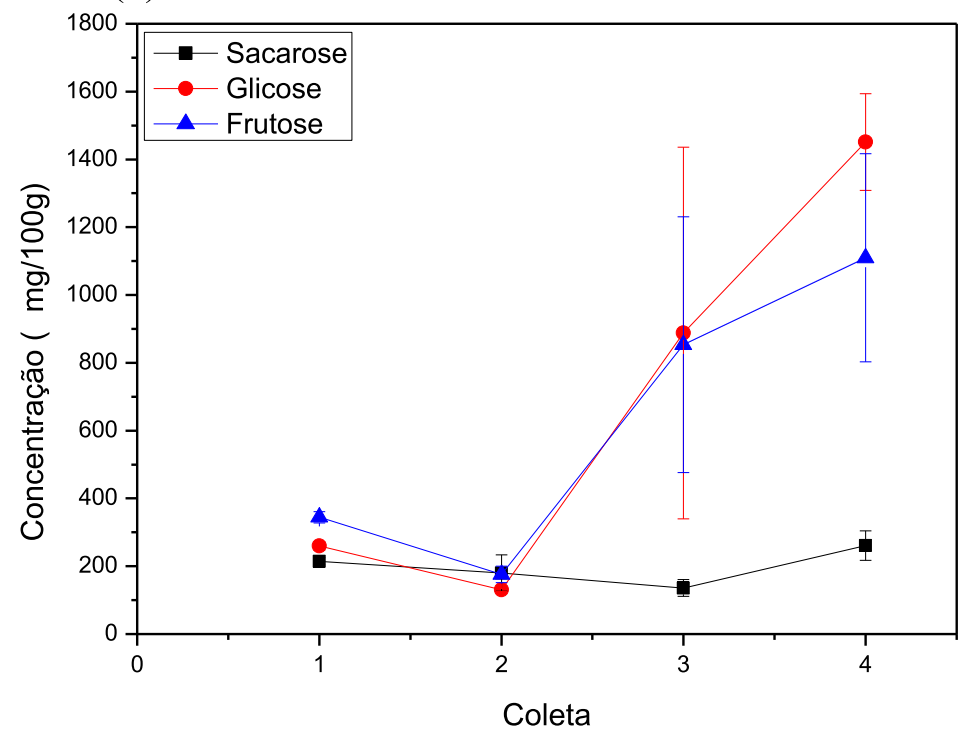

$\mathrm{Na}$ ausência de adubação nitrogenada $\left(\mathrm{N}_{0}\right)$ foi observado um aumento dos açúcares redutores com o desenvolvimento, enquanto que no teor de sacarose foi observada uma diminuição até a terceira coleta, seguido por um ligeiro aumento na coleta 4 . Da mesma forma, para adubação $\mathrm{N}_{1}$ houve um aumento da glicose e frutose, principalmente em relação às coletas 3 e 4 , e uma diminuição da sacarose.

$\mathrm{O}$ aumento dos açúcares redutores também foi observado para adubação $\mathrm{N}_{2}$ até a terceira coleta, seguida por um decréscimo na última coleta, o que não foi significativo estatisticamente. Já a sacarose apresentou um aumento com o desenvolvimento do fruto para essa adubação. 
$\mathrm{Na}$ adubação máxima $\left(\mathrm{N}_{3}\right)$, tanto os açúcares redutores quanto a sacarose aumentaram com o desenvolvimento do fruto. Porém, o crescimento observado pela sacarose não foi significativo estatisticamente, assim como a variação da frutose entre as duas últimas coletas.

El Bulk, Babiker e Tinay (1997) avaliaram a variação dos açúcares solúveis em quatro cultivares de goiaba, a partir de 15 dias após a frutificação até a total maturação, utilizando método colorimétrico, e observaram um aumento dos açúcares totais com o desenvolvimento. Durante a maturação, a goiaba cv. Banarsi Surkha apresentou um aumento dos açúcares redutores (glicose e frutose) assim como dos não redutores (sacarose), no entanto o aumento foi mais pronunciado em relação aos açúcares redutores (JAIN et al., 2003), assim como o observado para goiaba Paluma do vale do São Francisco (LIMA et al., 2008), comportamento semelhante ao encontrado para adubação $\mathrm{N}_{0}$ e $\mathrm{N}_{3}$ neste trabalho.

Geralmente na fruta madura predominam os açúcares redutores em relação à sacarose. No entanto, no trabalho de El Bulk, Babiker e Tinay (1997) goiabas maduras de três cultivares apresentaram maior concentração de frutose e sacarose, sendo que apenas para uma das cultivares a frutose e glicose predominaram em relação à sacarose. Os autores ressaltam que esse comportamento pode estar relacionado com diferenças fisiológicas entre as cultivares.

A maior concentração dos açúcares redutores em relação à sacarose com o desenvolvimento do fruto pode estar relacionada ao fato da glicose e a frutose serem originadas da degradação da sacarose e de polissacarídeos de reserva. Além disso, segundo Esteves e Carvalho (1982), o acréscimo desses açúcares está relacionado ao aumento do grau de doçura durante a maturação, proporcionando características adequadas para o consumo.

Em relação à adubação, a dose máxima de nitrogênio $\left(\mathrm{N}_{3}\right)$ proporcionou um aumento nos açúcares redutores na primeira coleta em relação às demais adubações. Comportamento contrário foi observado na segunda coleta, na qual houve uma diminuição dos açúcares com a adubação máxima, com exceção da sacarose, que em $\mathrm{N}_{3}$ apresentou um aumento em relação a $\mathrm{N}_{1}$ e $\mathrm{N}_{2}$.

Os açúcares redutores foram encontrados em menor concentração nas amostras adubadas com $\mathrm{N}_{3}$ em relação às adubadas com $\mathrm{N}_{2}$ na terceira coleta, no entanto em maior concentração que nas amostras de $\mathrm{N}_{0}$ e $\mathrm{N}_{1}$. Já a sacarose apresentou um acréscimo com o aumento da dose de adubação nitrogenada. Na goiaba madura foi possível observar que a maior dose de adubação $\left(\mathrm{N}_{3}\right)$ causou um efeito negativo nos açúcares redutores, a qual apresentou valores próximos das amostras sem adubação $\left(\mathrm{N}_{0}\right)$, enquanto que a sacarose aumentou com a dose da adubação, o que pode ser explicado pelo fato de sua degradação ser 
uma das fontes dos açúcares redutores, consequentemente, quanto menor for sua degradação menor o teor dos açúcares redutores. Já as adubações $\mathrm{N}_{1}$ e $\mathrm{N}_{2}$ apresentaram valores próximos.

Ao contrário do que o foi observado neste trabalho para cv. Paluma da região de Jaboticabal, a goiaba Paluma do vale do São Francisco não apresentou aumento dos açúcares solúveis com o aumento da adubação nitrogenada (LIMA et al., 2008). Este fato pode estar relacionado ao tempo em que esta adubação estava sendo aplicada nas plantas, além de diferenças climáticas, uma vez que as condições climáticas da região nordeste, com alta insolação e calor durante grande parte do ano, proporciona síntese e acúmulo de açúcares nos frutos.

\subsubsection{Pectina}

\subsubsection{Extração}

Para caracterização dos açúcares presentes na pectina foi realizada uma extração ácida da pectina das goiabas. Após a extração seguida da precipitação em solução etanólica obtevese um material com aspecto gelatinoso, ilustrado na Figura 15.

Figura 15 - Pectina extraída da goiaba triturada em solução etanólica.

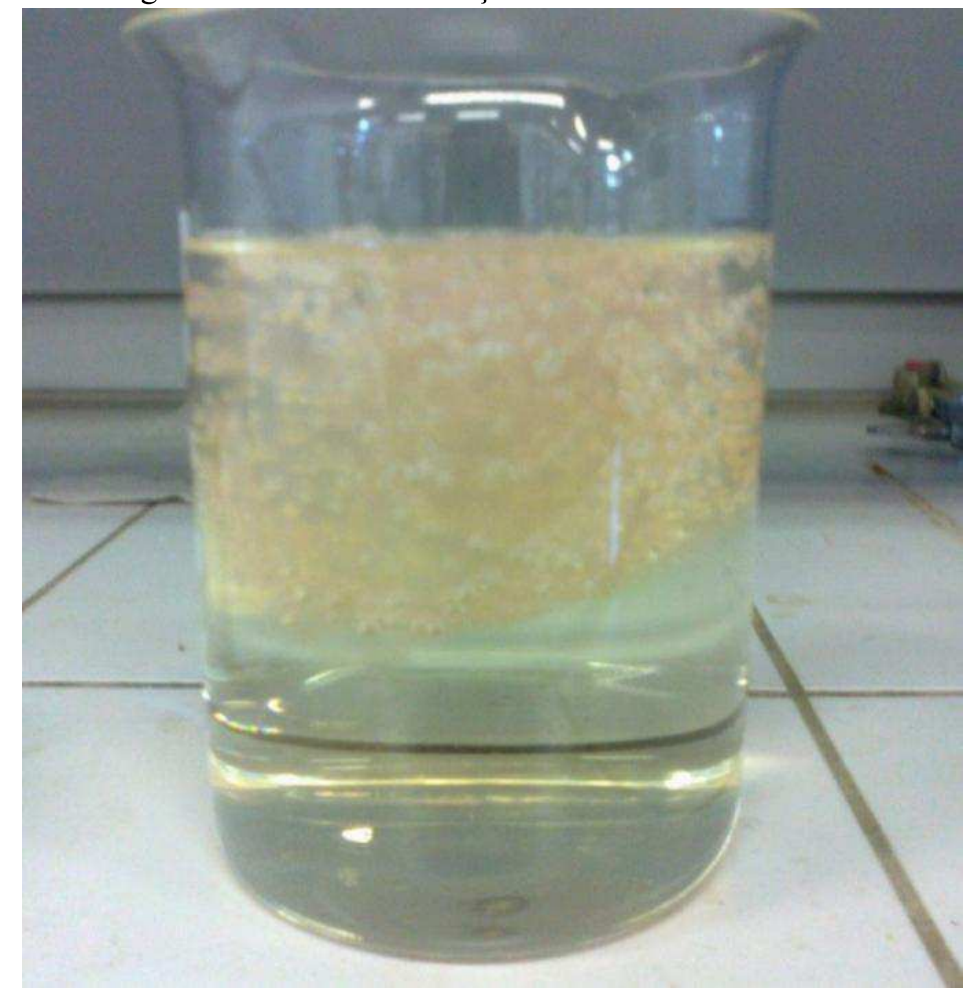


À medida que ocorre o amadurecimento do fruto ocorre a diminuição da firmeza, o que tem sido atribuído a modificações e degradação dos componentes da parede celular, entre eles a pectina (ANDREWS e LI 1984). Segundo relatado por El Bulk, Babiker e El Tinay (1997), a pectina total aumentou com o desenvolvimento em quatro diferentes cultivares de goiaba naturais do Sudão. Neste trabalho, no entanto, não foi observado um aumento constante no rendimento das extrações como pode ser observado na Tabela 10.

Tabela 10 - Rendimento da extração de pectina $\left(\mathrm{N}_{0}=0 \mathrm{~g}\right.$ de $\mathrm{N} ; \mathrm{N}_{1}=500 \mathrm{~g}$ de N$; \mathrm{N}_{2}=1000 \mathrm{~g}$ de N; $\mathrm{N}_{3}=2000 \mathrm{~g}$ de N).

\begin{tabular}{c|c|cccc}
\hline \multirow{2}{*}{ Pectina } & Coletas 2010 & \multicolumn{4}{|c}{ Adubação } \\
\cline { 3 - 6 } & & N0 & N1 & N2 & N3 \\
\hline \multirow{3}{*}{$\begin{array}{c}\text { Rendimento } \\
\text { (\%) }\end{array}$} & Coleta 1 & 9,00 & 11,20 & 10,80 & 8,40 \\
& Coleta 2 & 31,40 & 31,43 & 6,60 & 15,22 \\
& Coleta 3 & 14,22 & 2,33 & 4,61 & 36,82 \\
& Coleta 4 & 33,51 & 17,35 & 12,94 & 8,78 \\
\hline
\end{tabular}

Pelos resultados apresentados na Tabela 10 observou-se que nas condições de extração utilizadas, a goiaba apresentou uma diminuição do teor de pectina com o aumento da adubação nitrogenada, proporcionando uma fonte mais pobre de pectina.

No trabalho de Gonçalves et al., (2006) foi observado que o teor de pectina total durante o desenvolvimento do fruto de figueira aumentou gradativamente até 45 dias, sendo que a partir de então houve um decréscimo. O aumento dos teores de pectina total, até os 45 dias, pode ser explicado pelos íons cálcio que se associam ao ácido poligalacturônico formando pectatos de cálcio, conferindo maior rigidez ao tecido vegetal. A redução na porcentagem de pectina total a partir dos 45 dias coincide com a intensa atividade de enzimas que degradam a pectina e consequente aumentam a solubilização (GONÇALVES et al., 2006).

\subsubsection{Caracterização dos açúcares neutros presentes na pectina}

Assim como para os açúcares neutros solúveis na goiaba, a análise dos açúcares presentes na pectina foi avaliada por eletroforese capilar. Depois de estabelecidas as condições de separação realizou-se a construção de uma curva analítica para cada açúcar 
estudado presente na estrutura da pectina, sendo eles galactose, glicose, ramnose, arabinose e xilose. Os resultados obtidos para cada curva analítica, assim como os limites de detecção e quantificação encontrados são apresentados na Tabela 11.

Tabela 11 - Equações de regressão linear, coeficientes de correlação, limite de detecção (LD), limite de quantificação (LQ) e faixa de concentração estudada para cada um dos açúcares.

\begin{tabular}{|c|c|c|c|c|c|}
\hline Açúcares & $\begin{array}{c}\text { Equaç̧ão da reta } \\
\mathbf{Y}=\mathbf{A}+\mathbf{B X}\end{array}$ & $\begin{array}{l}\text { Coeficiente de } \\
\text { correlação }\end{array}$ & $\underset{\left(m g ~ m L^{-1}\right)}{\mathbf{L D}}$ & $\begin{array}{c}\text { LQ } \\
\left(\mathrm{mg} \mathrm{mL}^{-1}\right)\end{array}$ & $\begin{array}{l}\text { Faixa estudada } \\
\quad\left(\mathrm{mg} \mathrm{mL}^{-1}\right)\end{array}$ \\
\hline Galactose & $Y=-17149,84+8,510 * 10^{5} \mathrm{X}$ & 0,994 & 0,025 & 0,085 & $0,01-0,40$ \\
\hline Glicose & $Y=-14454,96+8,186^{*} 10^{5} X$ & 0,988 & 0,035 & 0,118 & $0,01-0,40$ \\
\hline Ramnose & $\mathrm{Y}=-1705,427+3,072 * 10^{5} \mathrm{X}$ & 0,992 & 0,032 & 0,106 & $0,01-0,40$ \\
\hline Arabnose & $Y=-12474,54+6,479 * 10^{5} \mathrm{X}$ & 0,988 & 0,040 & 0,133 & $0,01-0,40$ \\
\hline Xilose & $\mathrm{Y}=-6176,41+5,855 * 10^{5} \mathrm{X}$ & 0,984 & 0,042 & 0,139 & $0,01-0,40$ \\
\hline
\end{tabular}

Os coeficientes de correlação entre a concentração de cada açúcar e sua área de pico variaram entre 0,984 e 0,994 para xilose e galactose respectivamente, indicando excelente linearidade. Os valores de LD e LQ foram determinados segundo a fórmula descrita pela Anvisa (ANVISA, 2003), que considera, respectivamente, a razão entre três e dez vezes o desvio padrão dos interceptos das curvas analíticas $\left(\mathrm{DP}_{\mathrm{a}}\right)$ e as inclinações $(\mathrm{IC})$ das mesmas (ANVISA, 2003).

A repetibilidade foi determinada por seis injeções consecutivas durante um dia, e a precisão entre dias foi determinada por três injeções consecutivas, durante três dias. Os resultados do coeficiente de variação $(\mathrm{CV} \%)$ para tempo de retenção e área de pico podem ser vistos na Tabela 12. 
Tabela 12 - Precisão do método para análises intra-dia e entre-dias.

\begin{tabular}{c|cc|cc}
\hline \multirow{2}{*}{ Açúcares } & \multicolumn{2}{|c|}{ Repetibilidade $(\mathbf{n}=\mathbf{6})$} & \multicolumn{2}{c}{ Precisão Intermediária $(\mathbf{n}=\mathbf{9}) *$} \\
\cline { 2 - 5 } & $\begin{array}{c}\mathrm{CV}(\%) \\
\text { tempo de migração }\end{array}$ & $\begin{array}{c}\mathrm{CV}(\%) \\
\text { área de pico }\end{array}$ & $\begin{array}{c}\mathrm{CV}(\%) \\
\text { tempo de migração }\end{array}$ & $\begin{array}{c}\mathrm{CV}(\%) \\
\text { área de pico }\end{array}$ \\
\hline Galactose & 2,29 & 10,00 & 4,17 & 7,00 \\
Glicose & 2,43 & 6,00 & 4,51 & 7,00 \\
Rhamnose & 2,53 & 4,00 & 4,84 & 9,00 \\
Arabnose & 2,57 & 8,00 & 4,64 & 10,00 \\
Xylose & 2,93 & 3,00 & 5,33 & 10,00 \\
\hline
\end{tabular}

$\mathrm{CV} \%=(\mathrm{DP} /$ média $) \times 100$

* três injeções consecutivas por 3 dias não consecutivos

Assim como descrito anteriormente na análise de açúcares livres presentes na goiaba, o método apresentou altos valores de coeficiente de variação, principalmente para área de pico, sendo que os valores em um mesmo dia variaram de $3 \%$ para xilose a $10 \%$ para galactose. Para análises em dias distintos o CV (\%) variou entre 7\% para galactose e glicose e $10 \%$ para xilose. Esta baixa repetibilidade, expressa pelos altos valores de coeficientes de variação, pode ser explicada pela degradação dos açúcares em meio fortemente básico, condições necessárias para análise destes compostos pelo método proposto.

Na Figura 16 é possível observar um eletroferograma referente à mistura de padrões e a uma amostra de pectina hidrolisada, na qual a identificação dos açúcares foi realizada com base na comparação do tempo de migração de padrões com a amostra, e confirmados pela adição de cada padrão à amostra. 
Figura 16: Eletroferogramas referentes (a) mistura de padrões e (b) ao produto de hidrólise da amostra N mistura de padrões.

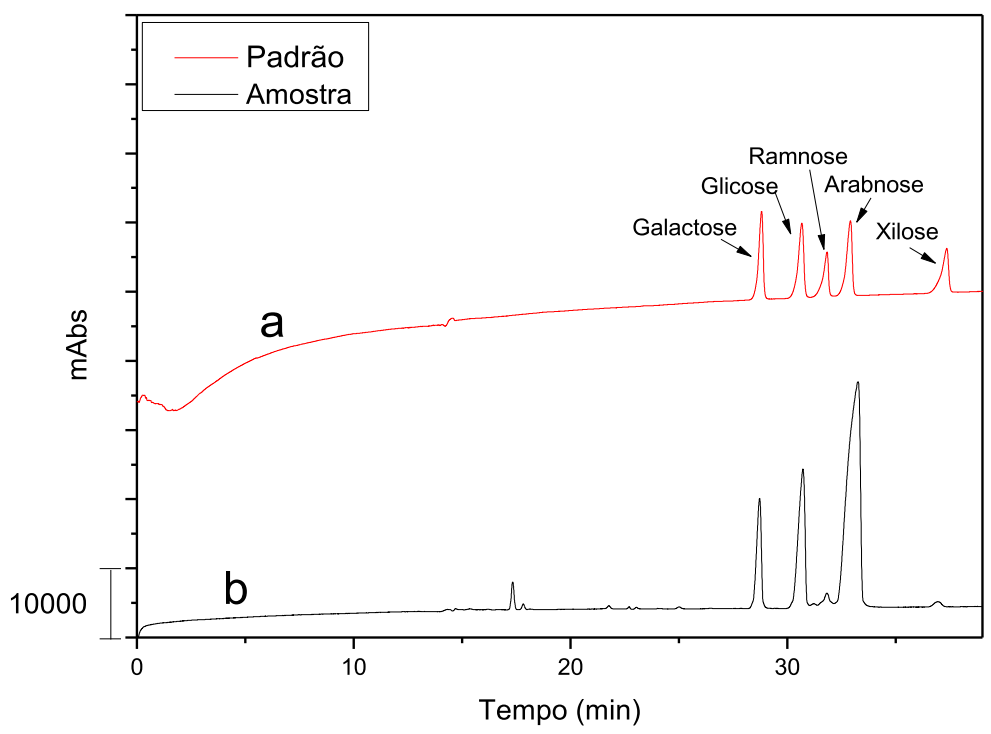

Nas metodologias descritas para hidrólise da pectina não se encontra um consenso entre o melhor tempo de hidrólise, por isso, foi realizada a hidrólise ácida da pectina para obtenção dos açúcares neutros em três tempos diferentes: $t_{1}=3 h ; t_{2}=6 h$ e t $t_{3}=10 h$. Na Tabela 13 observa-se a razão molar obtida entre os açúcares estudados.

Tabela 13 - Razão molar entre os principais açúcares neutros encontrados para uma amostra aleatória de pectina, hidrolisada em 3 diferentes tempos.

\begin{tabular}{c|ccccc}
\hline $\begin{array}{c}\text { Tempo da } \\
\text { hidrólise }\end{array}$ & \multicolumn{5}{|c}{ Razão Molar } \\
\hline & Gal & Glc & Rha & Ara & Xyl \\
$3 \mathrm{~h}$ & 1,00 & 1,56 & nd & 8,64 & nd \\
$6 \mathrm{~h}$ & 1,00 & 1,19 & nd & 7,53 & nd \\
$10 \mathrm{~h}$ & 1,49 & 2,17 & 1,00 & 11,95 & nd \\
\hline
\end{tabular}

Com base nos resultados apresentados acima foi possível observar que a maior proporção foi obtida na amostra hidrolisada durante $10 \mathrm{~h}$, e a partir de então, foi realizada a extração da pectina de todas as amostras, que foram hidrolisadas por $10 \mathrm{~h}$. Na Tabela 14 pode-se observar a proporção dos principais açúcares neutros identificados nas amostras estudadas a partir da hidrólise ácida da pectina durante $10 \mathrm{~h}$. 
Tabela 14 - Proporção dos principais açúcares neutros presentes na pectina (média \pm desvio padrão) durante o desenvolvimento nas diferentes adubações $\left(\mathrm{N}_{0}=0 \mathrm{~g}\right.$ de $\mathrm{N} ; \mathrm{N}_{1}=500 \mathrm{~g}$ de N; $\mathrm{N}_{2}=1000 \mathrm{~g}$ de N; $\mathrm{N}_{3}=2000 \mathrm{~g}$ de $\mathrm{N})$.

\begin{tabular}{|c|c|c|c|c|c|}
\hline \multirow{2}{*}{$\begin{array}{l}\text { Hidrolisado } \\
\text { da pectina }\end{array}$} & \multirow{2}{*}{$\begin{array}{c}\text { Coletas } \\
2011\end{array}$} & \multicolumn{4}{|c|}{ Adubação } \\
\hline & & No & N1 & N2 & N3 \\
\hline Açúcares & & Gal:Gli:Rha:Ara:Xil & Gal:Gli:Rha:Ara:Xil & Gal:Gli:Rha:Ara:Xil & Gal:Gli:Rha:Ara:Xil \\
\hline \multirow{4}{*}{$\begin{array}{l}\text { Razão } \\
\text { Molar }\end{array}$} & Coleta 1 & $1,13: 1,20: 1,18: 2,05: 1,00$ & $1,17: 1,83: 1,00: 2,67:$ nd & $1,00: 1,42: 0: 2,48:$ nd & $1,00: 1,12: \mathrm{nd}: 1,59: 1,17$ \\
\hline & Coleta 2 & $1,00: 1,62: \mathrm{nd}: 2,14: \mathrm{nd}$ & $1,12: 1,31: 1,00: 3,10:$ nd & $1,37: 1,77: 1,00: 3,05: \mathrm{nd}$ & $1,12: 1,71: 1,00: 2,59: \mathrm{nd}$ \\
\hline & Coleta 3 & $1,27: 6,06: 1,15: 3,24: 1,00$ & $1,32: 1,00: 1,02: 2,39:$ nd & $1,74: 2,35: 1,27: 4,49: 1,00$ & $1,04: 3,53: 1,00: 3,21:$ nd \\
\hline & Coleta 4 & $1,03: 18,78: 1,04: 2,38: 1,11$ & $1,29: 21,35: 1,08: 4,59: 1,09$ & $1,25: 50,05: 5,30: 1,00: 1,53$ & $1,28: 29,95: 1,00: 5,22: 1,26$ \\
\hline
\end{tabular}

Pelos resultados apresentados na Tabela 14, é possível observar que até a segunda coleta a arabinose se destaca como sendo o principal açúcar presente na pectina proveniente de extração ácida da goiaba. Na mesma coleta pode-se ver que a glicose vem em segundo lugar e em terceiro a galactose, sendo que a ramnose e a xilose não foram detectadas com o método utilizado para algumas adubações. Na terceira coleta, a glicose se destaca em relação aos demais açúcares para as adubações $\mathrm{N}_{0}$ e $\mathrm{N}_{3}$, seguida por arabinose, galactose, ramnose e xilose, enquanto que para as adubações $\mathrm{N}_{1}$ e $\mathrm{N}_{2}$ a arabinose é encontrada em maior proporção. A quarta coleta chamou a atenção pelo fato da grande diferença da razão molar da glicose em relação aos demais açúcares para todas as adubações. Em geral, em segundo lugar está presente a arabinose, com exceção da amostra $\mathrm{N}_{2}$, na qual a ramnose está presente em maior proporção. Os resultados obtidos nesse trabalho diferem dos obtidos para goiaba cv. Kumagai, na qual houve predominância da xilose, que não foi detectada em grande parte das nossas amostras, seguida pela arabinose e galactose (CARVALHO et al., 2001).

Vale ressaltar que a composição monossacarídica neutra da pectina pode variar por diferentes fatores, dentre eles fonte vegetal, método de extração e tratamento químico após a extração (hidrólise) (FISHMAN et al., 1984; HWANG, PYUN e KOKINI, 1993). No entanto, segundo Fishman et al. (1984), geralmente a pectina possui principalmente arabinose, galactose e ramnose como açúcares neutros, o que também foi encontrado nas nossas amostras, e pequenas quantidades de glicose, manose e xilose (FISHMAN et al, 1984). Hwang e Konini (1992) destacam a arabinose, galactose e xilose como os principais açúcares neutros, seguidos por glicose, manose e fucose (HWANG, PYUN e KOKINI, 1993). Segundo Duan et al. (2008), os principais açúcares neutros da pectina provenientes de extração ácida na banana são manose e arabinose, seguido por uma pequena quantidade, muitas vezes não detectável de ramnose, xilose e frutose (DUAN et al., 2008). No maracujá determinou-se que os principais açúcares neutros presentes na pectina foram ramnose, arabinose e galactose 
(PINHEIRO, 2007), enquanto que na maça, galactose e xilose são os principais constituintes, seguidos pela arabinose, em quantidade relativamente menor (HWANG \& KOKINI, 1992).

Como pode ser observado em relação aos trabalhos citados, a composição monossacarídica da pectina é muito variável, no entanto, a glicose é a que menos se destaca entre os estudos, enquanto que nos resultados apresentados para a coleta 4 ela teve grande importância. Uma das possíveis explicações para a grande proporção da glicose em relação aos demais açúcares pode vir do fato de que antes da extração da pectina é realizada uma lavagem das amostras para retirada dos açúcares livres presentes na goiaba. Essa etapa foi realizada da mesma forma para todas as amostras, no entanto, as goiabas maduras apresentam teores maiores desses açúcares, dentre eles a glicose. Portanto, a alta concentração de glicose nas goiabas das duas últimas coletas pode ser atribuída a contaminação da glicose presente na amostra, que possivelmente pode não ter sido totalmente retirada na etapa de lavagem.

$\mathrm{Na}$ Figura 17 é possível observar o comportamento dos monossacarídeos da pectina das amostras em relação à coleta, para cada adubação, hidrolisadas nas condições descritas anteriormente.

Figura 17 - Variação da razão molar dos açúcares neutros da pectina com o desenvolvimento nas quatro diferentes adubações: (a) $\mathrm{N}_{0}$; (b) $\mathrm{N}_{1}$; (c) $\mathrm{N}_{2}$; (d) $\mathrm{N}_{3}$.

(a)

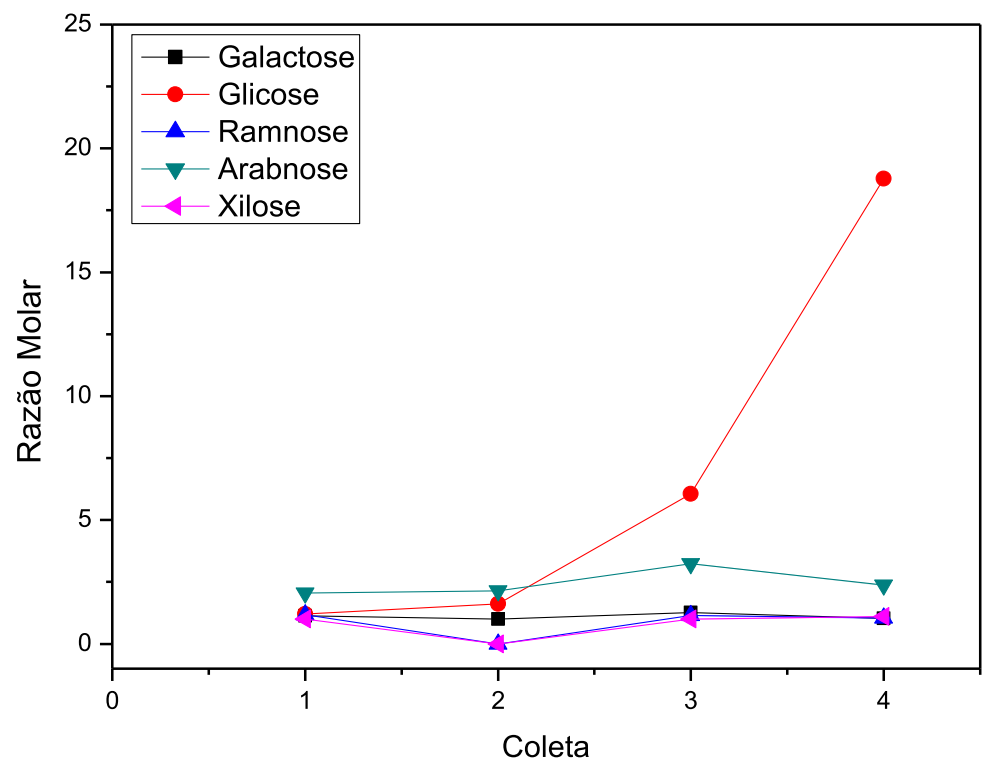


(b)

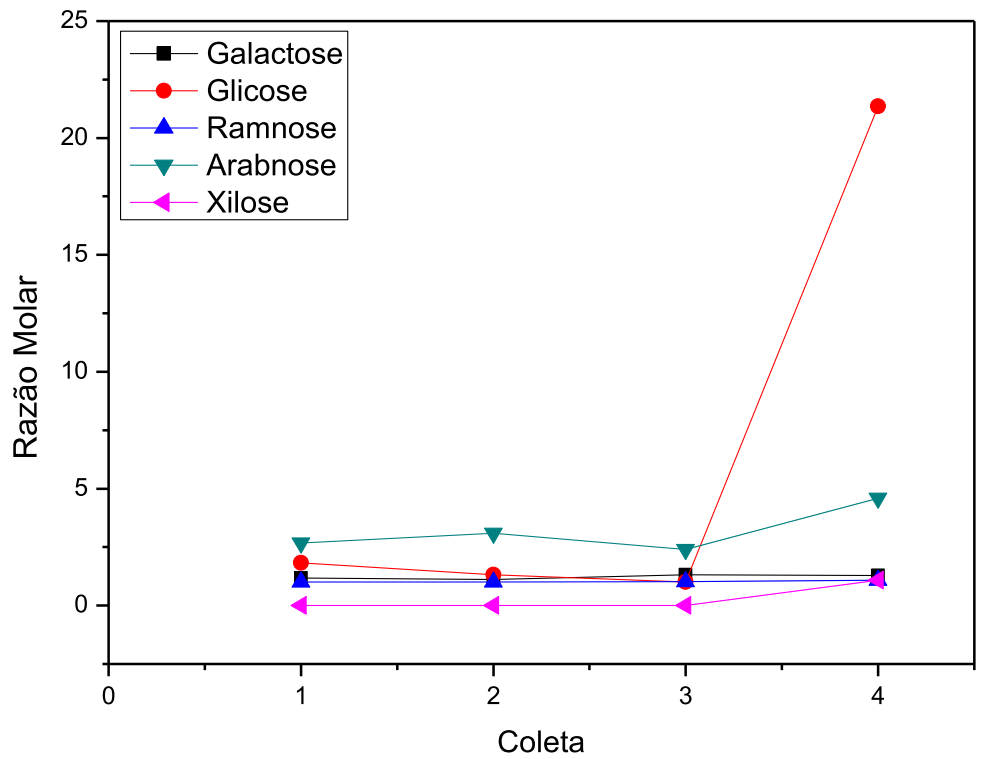

(c)

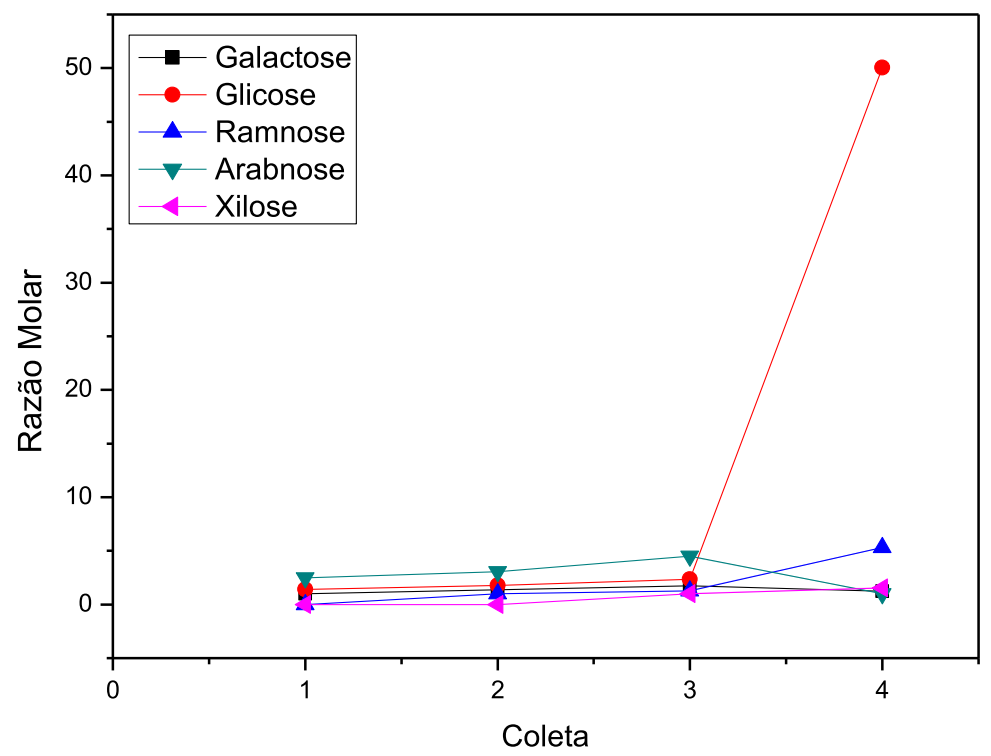


(d)

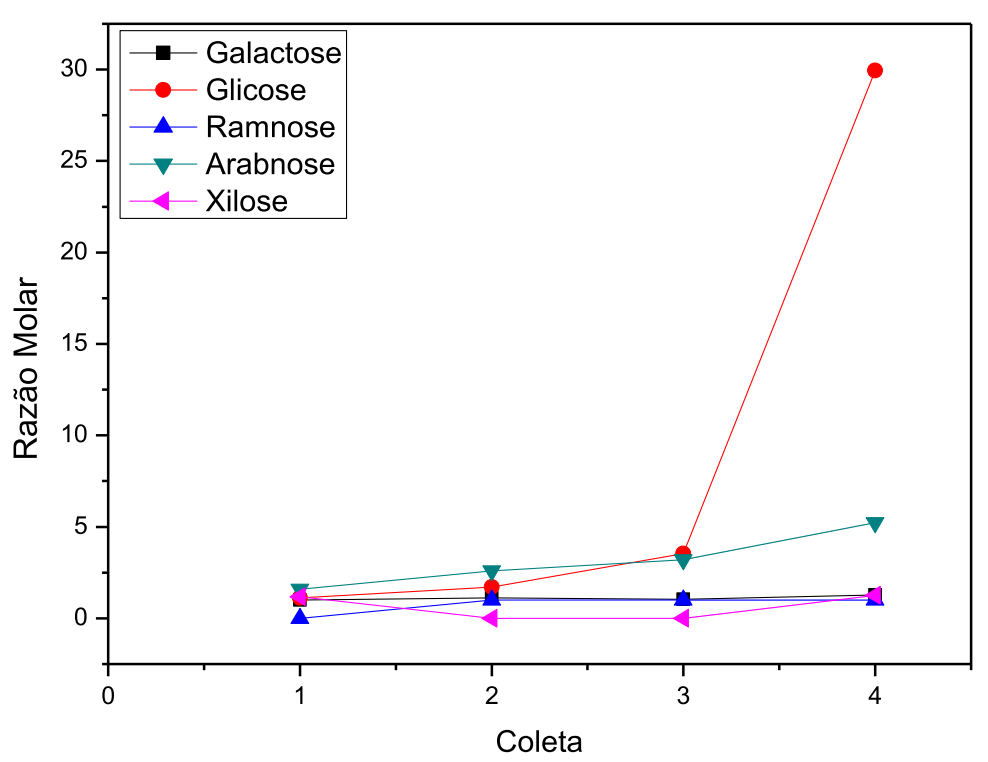

Com o desenvolvimento, as amostras se comportaram de forma diferente para cada adubação. No entanto, em geral foi observado um aumento da glicose, com exceção da adubação $\mathrm{N}_{1}$, a qual apresentou uma leve diminuição até a terceira coleta, seguida por um aumento acentuado entre a terceira e a última coleta. Outro açúcar que merece ser destacado é a arabinose, que em $\mathrm{N}_{0}$ e $\mathrm{N}_{3}$ apresentou um aumento com a o desenvolvimento da goiaba, sendo que em $\mathrm{N}_{1}$ houve uma diminuição na coleta 3 em relação as coletas 1 e 2 , seguida novamente de um aumento na coleta 4 , e $\mathrm{N}_{2}$ que teve um aumento da coleta 1 à coleta 3 seguido por uma diminuição na coleta 4 .

Em banana, a proporção de galactose aumentou com o desenvolvimento da fruta até o estádio maduro, o que pode ser consequência da quebra gradual da cadeia principal da pectina. No entanto os demais açúcares presentes não sofreram alterações significativas durante o amadurecimento (DUAN et al., 2008). Em figo, foi observada uma perda da galactose e arabinose, e segundo Gonçalves et al. (2006), diferentes trabalhos tem relatado a perda dos açúcares neutros da pectina durante o amadurecimento de manga, pêra e tomate (GONÇALVES et al., 2006).

As amostras também foram avaliadas em relação às diferentes doses de adubação, e como pode ser observado para a primeira coleta a máxima dose de adubação nitrogenada levou a um aumento da xilose e decréscimo dos demais açúcares. A glicose, arabinose e galactose apresentaram maiores teores na adubação $\mathrm{N}_{1}$; já a ramnose, na adubação $\mathrm{N}_{0} . \mathrm{Na}$ segunda coleta não foi possível detectar xilose para nenhuma das adubações. Nas amostras 
adubadas não houve variação da ramnose, no entanto ela não foi observada nas amostras sem adubação. A adubação N2 proporcionou maiores teores de glicose e galactose e N1 maiores teores de arabnose. A glicose e xilose apresentaram maiores teores na adubação N0 na terceira coleta, enquanto que os demais açúcares em $\mathrm{N}_{2}$. A goiaba madura (coleta 4) apresentou maiores teores de glicose, ramnose e xilose para adubação $\mathrm{N}_{2}$, enquanto que a arabinose foi maior em $\mathrm{N}_{3}$.

Não foi encontrado na literatura relação entre os açúcares neutros da pectina e a variação da adubação nitrogenada. Sabe-se que os açúcares neutros presentes nas cadeias laterais são os responsáveis pela união das moléculas de pectina à matriz polissacarídica da parede celular vegetal (HWANG; KOKINI, 1992), no entanto não foi encontrada na literatura uma relação entre a qualidade da pectina obtida em relação aos açúcares neutros presentes.

\subsubsection{Vitamina C}

\subsubsection{Extração}

Apesar da vitamina C ser uma vitamina hidrossolúvel, e por isso poder ser extraída apenas com água, ela é facilmente oxidada, havendo necessidade de aumentar a estabilidade do ácido ascórbico recém-extraído da matriz de alimento. A sua estabilidade após a extração está diretamente relacionada ao meio extrator e às condições de manipulação, como luz e temperatura, que afetam significantemente a recuperação do ácido ascórbico (ROSA et al., 2007).Por isso teve-se cuidado para que as amostras tivessem o menor contato possível com a luz, o que foi possível com a utilização de vidrarias e tubos Falcon envolvidos por papel laminado, assim como a utilização de frascos âmbar e sacos plástico pretos.

Para extração do ácido ascórbico, a goiaba processada foi colocada em contato com uma solução de EDTA e ácido fosfórico. Essa solução agiu como estabilizante, no intuito de evitar e/ou minimizar a oxidação do ácido ascórbico durante sua extração. O EDTA é capaz de retirar íons metálicos como ferro e cobre do meio, os quais aumentam a oxidação do ácido ascórbico (HERNÁNDEZ, LOBO e GONZÁLEZ, 2006; ROSA et al., 2007; CAMPOS et al., 2009). Em seguida parte dessa amostra foi colocada em contato com a solução extratora, composta por ácido oxálico e EDTA, o qual tem a função de estabilizar o ácido ascórbico, reduzindo a ação enzimática (WIMALASIRI e WILLS, 1983; CAMPOS et al., 2009). Após esta etapa, cada amostra foi dividida em duas partes, já que a vitamina $\mathrm{C}$ pode ser encontrada 
na fruta em sua forma reduzida (ácido ascórbico) e oxidada (ácido desidroascórbico) (NAGY, 1980; LEE \& KADER, 2000) Para determinação do ácido ascórbico total, uma parte da amostra foi diretamente analisada e na segunda parte foi necessário realizar a redução do ácido desidroascórbico a ácido ascórbico. Para redução do ácido desidroascórbico utilizou-se L-cisteína (SCHIEWE, MRESTANI e NEUBERT, 1995; ZERDIN, ROONEY e VERMUE et al., 2003; VERSARI et al., 2004). A cisteína possui menor potencial de redução que do ácido ascórbico, agindo como antioxidante, auxiliando na estabilização do ácido ascórbico e na redução do ácido desidroascórbico a ácido ascórbico (SCHIEWE, MRESTANI e NEUBERT, 1995).

Todas as etapas foram realizadas em frascos cobertos com papel alumínio para manter as soluções e as amostras longe da luz e assim evitar a perda da vitamina C por degradação.

\subsubsection{Determinação de ácido ascórbico total e ácido desidroascórbico:}

Para determinação da vitamina $\mathrm{C}$ total e ácido desidroascórbico por eletroforese capilar foi construída uma curva de calibração analítica com a utilização de padrão de ácido ascórbico (Tabela 15).

Tabela 15 - Equação de regressão linear, coeficiente de correlação, limite de detecção (LD), limite de quantificação (LQ) e faixa de concentração estudada para o ácido ascórbico.

\begin{tabular}{|c|c|c|c|c|c|}
\hline Vitamina & $\begin{array}{c}\text { Equação da reta } \\
\qquad=\mathbf{A}+\mathbf{B X}\end{array}$ & $\begin{array}{c}\text { Coeficiente } \\
\text { de correlação }\end{array}$ & $\begin{array}{c}\text { LD } \\
\left(\mu \mathrm{g} \mathrm{mL}^{-1}\right)\end{array}$ & $\begin{array}{c}\mathrm{LQ} \\
\left(\mu \mathrm{g} \mathrm{m \mathbf {L } ^ { - 1 } )}\right.\end{array}$ & $\begin{array}{c}\text { Faixa } \\
\text { estudada } \\
\left(\mu \mathrm{g} \mathrm{mL}^{-1}\right)\end{array}$ \\
\hline $\begin{array}{c}\text { Ácido } \\
\text { Ascórbico }\end{array}$ & $Y=-2427,286+1164,566 * X$ & 0,999 & 1,01 & 3,36 & $2-120$ \\
\hline
\end{tabular}

Obteve-se um coeficiente de correlação de 0,999 para a faixa estudada, indicando excelente linearidade. Os valores de LD e LQ foram determinados segundo a ANVISA (ANVISA, 2003), sendo que o LD de $1,00 \mu \mathrm{g} \mathrm{mL}^{-1}$ está próximo do determinado por Liao et al, (2001), também por eletroforese capilar.

A repetibilidade foi determinada com seis injeções consecutivas durante um dia, e a precisão intermediária foi determinada com três injeções consecutivas, durante três dias, sendo que os testes foram realizados utilizando padrão de ácido ascórbico solubilizado em água no momento da análise, evitando contato com a luz, para que não houvesse degradação. 
Os resultados do coeficiente de variação (CV\%) para tempo de retenção e área de pico podem ser vistos na Tabela 16.

Tabela 16 - Precisão do método para análises intra-dia e entre-dias.

\begin{tabular}{c|cc|cc}
\hline \multirow{2}{*}{ Vitamina } & \multicolumn{2}{|c|}{ Repetibilidade $(\mathbf{n}=\mathbf{6})$} & \multicolumn{2}{c}{$\begin{array}{c}\text { Precisão Intermediária } \\
(\mathbf{n}=\mathbf{9}) *\end{array}$} \\
\cline { 2 - 5 } & $\begin{array}{c}\mathrm{CV}(\%) \\
\text { tempo de migração }\end{array}$ & $\begin{array}{c}\mathrm{CV}(\%) \\
\text { área de pico }\end{array}$ & $\begin{array}{c}\mathrm{CV}(\%) \\
\text { tempo de migração }\end{array}$ & $\begin{array}{c}\mathrm{CV}(\%) \\
\text { área de pico }\end{array}$ \\
\hline Ácido & 0,16 & 5 & 3,47 & 13 \\
Ascórbico & & & & \\
\hline
\end{tabular}

$\mathrm{CV} \%=(\mathrm{DP} /$ média $) \times 100$

* três injeções consecutivas por 3 dias não consecutivos

O método apresentou boa repetibilidade, com valores de coeficiente de variação de 0,16\% para tempo de migração e 5,00\% para área de pico. Os coeficientes de variação para precisão intermediária foram de 3,47\% para tempo de migração e 13,0\% para área de pico. Os valores de $\mathrm{CV}$ encontrados para área de pico foram elevados em relação ao tempo de migração, o que pode ser devido ao fato de a vitamina $\mathrm{C}$ ser uma vitamina extremamente lábil em contato com a luz e temperatura, e qualquer variação como o maior contato com a luz ou temperaturas mais altas durante o preparo da solução de padrão podem influenciar na variação das medidas entre os dias. Além disso, para os testes de repetibilidade o padrão ficou dentro do equipamento por no mínimo uma hora e cinquenta minutos até o término das 6 repetições. No entanto pode-se considerar que o método possui boa repetibilidade e reprodutibilidade.

Para determinação da recuperação do método de eletroforese capilar para análise de vitamina $\mathrm{C}$ foi utilizada uma amostra $\mathrm{N}_{2}$ da coleta 4 . Os valores para recuperação variaram entre 77 e 125\%, como pode ser observado na Tabela 17. 
Tabela 17 - Recuperação do método de eletroforese capilar.

\begin{tabular}{c|cccc}
\hline \multirow{2}{*}{ Vitamina } & \multicolumn{4}{|c}{ Concentração $\left(\boldsymbol{\mu g} \mathbf{~ m L}^{-1}\right)$} \\
\cline { 2 - 5 } & Adicionada & Amostra & Encontrada & $\begin{array}{c}\text { Recuperação } \\
(\%)\end{array}$ \\
\hline \multirow{2}{*}{$\begin{array}{c}\text { Ácido } \\
\text { ascórbico }\end{array}$} & 4 & & 24 & 100 \\
& 16 & 20 & 40 & 125 \\
\hline
\end{tabular}

$\operatorname{Rec}(\%)=[$ encontrada $]-[$ amostra $] \times 100$ [adicionada]

Após o estabelecimento do método foi realizada a extração das amostras, que foram analisadas logo em seguida como descrito anteriormente. Na Figura 18 pode-se ver os eletroferogramas de padrão e amostra obtidos nas análises.

Figura 18 - Eletroferogramas referente a (a) padrão e (b) amostra.

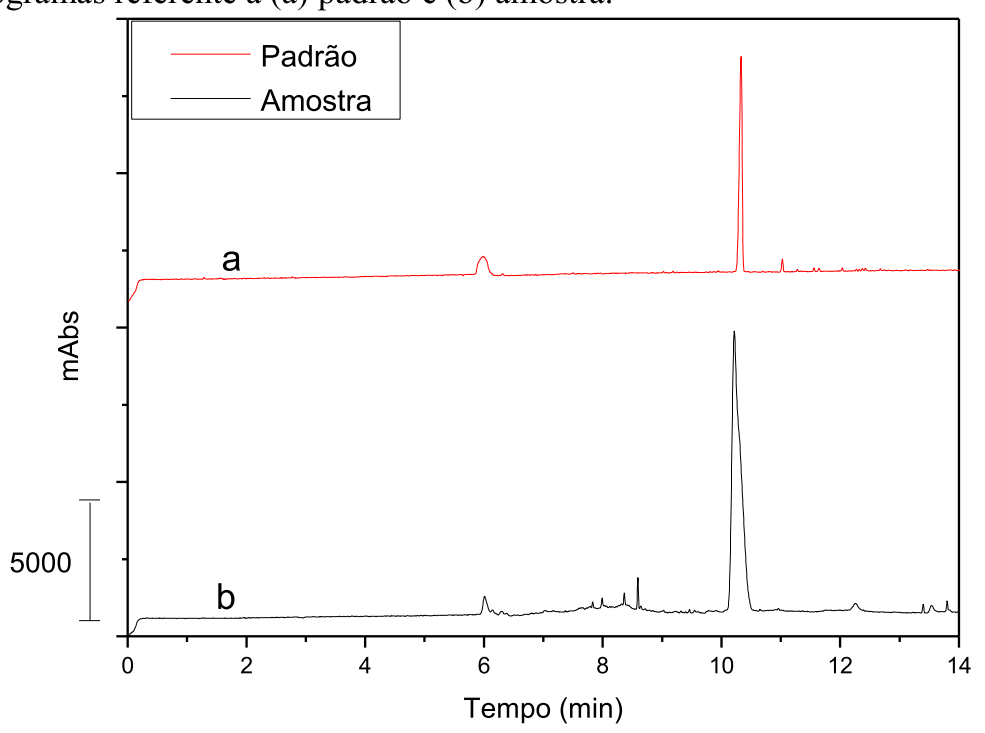

Para confirmação do pico do ácido ascórbico, foi realizada a adição de padrão na amostra, sendo que nenhum outro pico foi observado no eltroferograma além do aumento da intensidade do pico do ácido ascórbico.

Os resultados de quantificação obtidos a partir das curvas analíticas para todas as amostras são apresentados na Tabela 18. 
Tabela 18 - Concentração do ácido ascórbico (AA), ácido ascórbico total (AA Total) e ácido desidroascórbico (DIA), (média \pm desvio padrão) durante o desenvolvimento nas diferentes adubações.

\begin{tabular}{|c|c|c|c|c|c|}
\hline & \multirow{2}{*}{ Coletas 2010} & \multicolumn{4}{|c|}{ Adubação } \\
\hline & & No & N1 & $\mathbf{N} 2$ & $\mathbf{N 3}$ \\
\hline \multirow{4}{*}{$\underset{\left(m g 100 g^{-1}\right)}{\mathbf{A A}}$} & Coleta 1 & nd & nd & nd & nd \\
\hline & Coleta 2 & nd & nd & nd & nd \\
\hline & Coleta 3 & nd & $16,47^{\mathrm{aA}} \pm 4,03$ & $24,15^{\mathrm{bA}} \pm 5,79$ & $12,35^{\mathrm{aA}} \pm 0,81$ \\
\hline & Coleta 4 & $22,18^{\mathrm{aA}} \pm 1,04$ & $21,32^{\mathrm{aA}} \pm 3,84$ & $35,66^{\mathrm{bA}} \pm 2,57$ & $28,78^{\mathrm{cB}} \pm 6,48$ \\
\hline \multirow{4}{*}{$\begin{array}{l}\text { AA Total } \\
\left({\left.\mathrm{mg} 100 \mathrm{~g}^{-1}\right)}\right.\end{array}$} & Coleta 1 & nd & nd & nd & nd \\
\hline & Coleta 2 & nd & nd & nd & nd \\
\hline & Coleta 3 & nd & $29,88^{\mathrm{aA}} \pm 6,91$ & $35,05^{\mathrm{aA}} \pm 8,56$ & $13,46^{\mathrm{bA}} \pm 1,36$ \\
\hline & Coleta 4 & $29,66^{\mathrm{aA}} \pm 3,69$ & $41,03^{\mathrm{abA}} \pm 4,26$ & $63,95^{\mathrm{cB}} \pm 6,19$ & $53,80^{\mathrm{abcB}} \pm 13,63$ \\
\hline \multirow{4}{*}{$\underset{\left(m g 100 g^{-1}\right)}{\text { DIA }}$} & Coleta 1 & nd & nd & nd & nd \\
\hline & Coleta 2 & nd & nd & nd & nd \\
\hline & Coleta 3 & nd & $13,41^{\mathrm{bA}} \pm 3,36$ & $10,90^{\mathrm{bA}} \pm 3,44$ & $1,11^{\mathrm{aA}} \pm 1,39$ \\
\hline & Coleta 4 & $7,48^{\mathrm{aA}} \pm 3,62$ & $19,70^{\mathrm{aA}} \pm 6,99$ & $28,29^{\mathrm{aB}} \pm 8,51$ & $25,02^{\mathrm{aB}} \pm 8,80$ \\
\hline
\end{tabular}

Médias seguidas pela mesma letra $(\mathrm{a}, \mathrm{b}, \mathrm{c}$ e d) na linha não diferem entre si em relação à adubação pelo teste ANOVA, com 95\% de significância (0,05). Médias seguidas pela mesma letra (A e B) na coluna não difere entre si em relação aos estádios de desenvolvimento pelo teste ANOVA, com 95\% de significância $(0,05)$.

Como pode ser visto, a concentração de vitamina $\mathrm{C}$ nas amostras provenientes das duas primeiras coletas não atingiram níveis detectáveis por essa metodologia. Uma provável causa para a baixa concentração ao ponto de não ser detectável pode ter sido o longo tempo entre a coleta das amostras e o momento da análise.

Segundo Brunini, Oliveira e Varanda (2003), 18 dias após a coleta da goiaba cv.

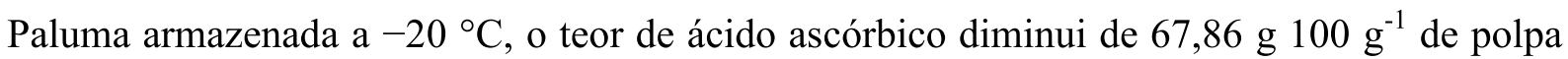
para 10,07 g $100 \mathrm{~g}^{-1}$, ou seja, houve uma perda considerável, sendo que o mesmo pode ter acontecido com as nossas amostras. Portanto, o longo tempo entre a coleta e as análises das primeiras amostras $\left(\mathrm{C}_{1}\right.$ e $\left.\mathrm{C}_{2}\right)$ podem ter impossibilitado a detecção do ácido ascórbico.

$\mathrm{O}$ ácido desidroascórbico representa menos de $10 \%$ da vitamina $\mathrm{C}$ total dos vegetais, tendendo a aumentar com o período de estocagem (ROSA et al., 2007). Segundo Wills, Wimalasiri e Greenfield (1984), o teor desse ácido varia tanto em relação à fruta ou vegetal estudado, quanto ao seu período de senescência. Ainda de acordo com os autores, em relação ao tempo que a fruta ou vegetal foi armazenado ocorreu um aumento no teor do ácido 
desidroascórbico. Como pode ser visto na Tabela 18, para as primeiras coletas também não foi possível determinar o ácido desidroascórbico.

Apesar de não ter sido possível determinar o teor da vitamina nas coletas $C_{1}$ e $C_{2}$ para goiaba madura, os valores de AA total encontrados para todas as adubações variaram entre 29,66 e 63,95 g $100 \mathrm{~g}^{-1}$ de polpa para $\mathrm{N}_{0}$ e $\mathrm{N}_{2}$, respectivamente. A adubação $\mathrm{N}_{2}$ proporcionou valores mais próximos aos encontrados na literatura, na qual a cv. Paluma apresentou teor de $58,74 \mathrm{mg}$ de ácido ascórbico $100 \mathrm{~g}^{-1}$ de polpa (FERNANDES et al., 2007).

Com os resultados destas primeiras amostras pode-se perceber um aumento do teor de vitamina $\mathrm{C}$ entre as duas últimas coletas, o que pode ser observado na Figura 19.

Figura 19 - Variação do (a) ácido ascórbico e (b) ácido ascórbico total em relação ao estádio de desenvolvimento nas quatro diferentes adubações.

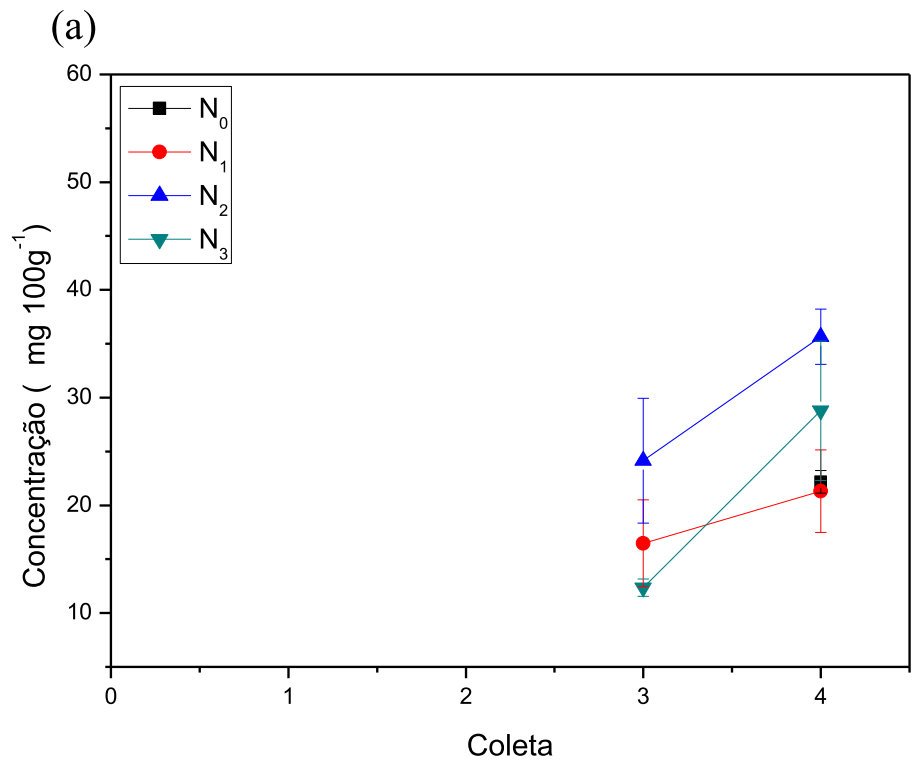


(b)

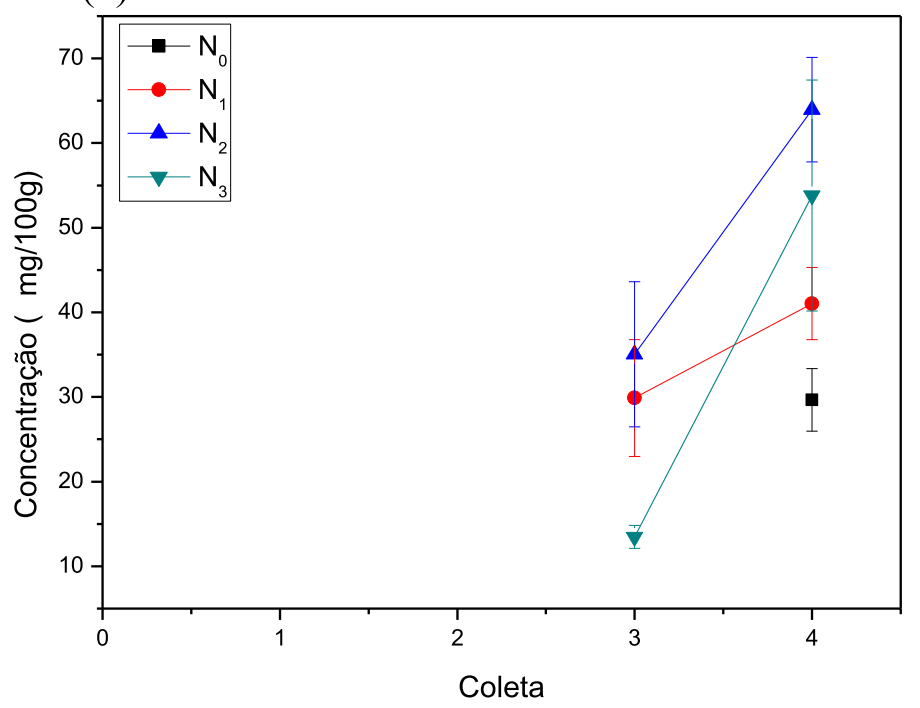

Em relação ao desenvolvimento, o aumento de AA foi significativo estatisticamente apenas na amostra adubada com $\mathrm{N}_{3}$, enquanto que AA total apresentou diferença significativa entre as amostras $\mathrm{N}_{0}, \mathrm{~N}_{2}$ e $\mathrm{N}_{3}$.

Segundo Gomez e Lajolo (2008), na goiaba há um aumento no teor de vitamina C total durante o desenvolvimento, indicando que a síntese de ácido ascórbico prevalece quando a necessidade por sua ação como antioxidante é necessária para a fruta. Goiabas de quatro cultivares diferentes naturais do Sudão também apresentaram um aumento significativo do teor de vitamina $\mathrm{C}$ durante a maturação, variando entre as cultivares de 88,2 a 113,3 $\mathrm{mg} 100$ $\mathrm{g}^{-1}$ (EL BULK, BABIKER e EL TINAY, 1997).

No trabalho de Silva, Bautista e Velasc (1998), a cultivar Media China apresentou um aumento no teor do ácido ascórbico na fruta madura em relação aos outros estádios, assim como no trabalho de Azzolini, Jacomino e Bron (2004), em que goiabas cv. Pedro Sato apresentaram teores maiores de ácido ascórbico no fruto em estádio avançado de maturação, variando de $30,35 \mathrm{mg} 100 \mathrm{~g}^{-1}$, 44,47 mg $100 \mathrm{~g}^{-1}$ e 48,77 mg $100 \mathrm{~g}^{-1}$ para os estádios verde, intermediário e maduro respectivamente. Também houve um aumento no teor do ácido desidroascórbico com o desenvolvimento do fruto, no entanto, essa variação foi significativa apenas nas adubações $\mathrm{N}_{2}$ e $\mathrm{N}_{3}$, como pode ser visto na Figura 20. 
Figura 20 - Variação do ácido desidroascórbico em relação ao estádio de desenvolvimento nas quatro diferentes adubações.

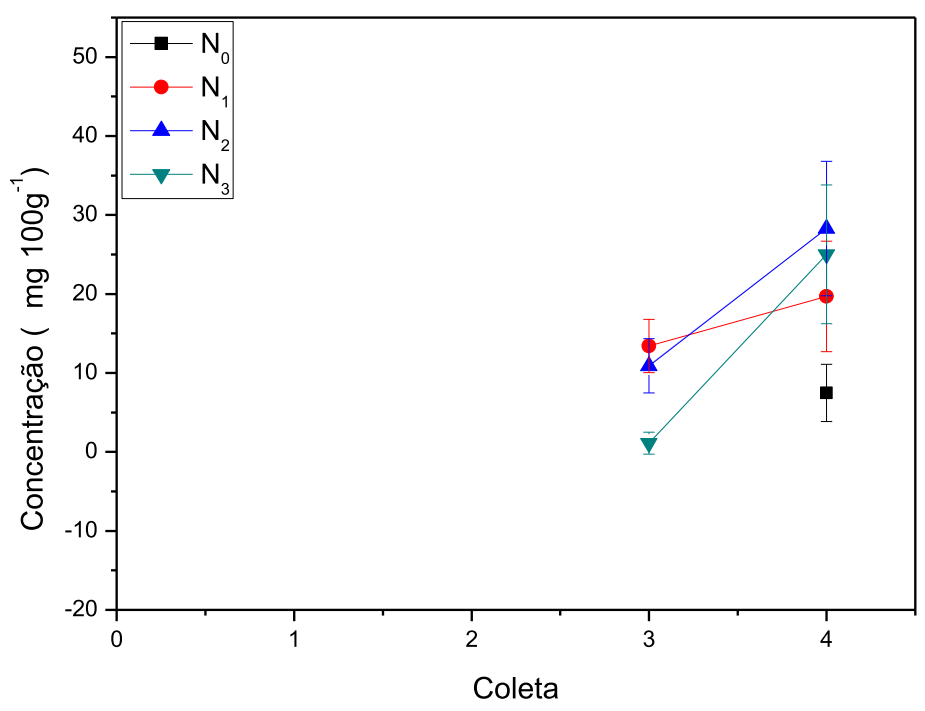

Em relação à adubação, $\mathrm{N}_{2}$ apresentou maiores teores de vitamina $\mathrm{C}$, tanto para coleta 3 quanto para coleta 4 , demonstrando que a adubação com altas doses de nitrogênio $\left(\mathrm{N}_{3}\right)$ não favorecem a produção de vitamina $C$. As adubações $\mathrm{N}_{1}$ e $\mathrm{N}_{3}$ não diferiram significativamente na coleta 3 , já na coleta $4, \mathrm{~N}_{2}$ e $\mathrm{N}_{3}$ diferem significativamente entre sim e em relação as demais para o teor de ácido ascórbico. Já para AA total, apenas na coleta 3 a adubação $\mathrm{N}_{3}$ difere significativamente das demais, enquanto que na coleta 4 , vale ressaltar que $\mathrm{N}_{2}$ e $\mathrm{N}_{3}$ não diferem entre si.

Lima et al. (2008), avaliaram a variação da adubação nos estádios de maturação, e observaram que cada estádio de maturação se comportou de forma diferente, dando destaque para a goiaba ainda verde, que apresentou uma diminuição no teor de vitamina $\mathrm{C}$ com o aumento da adubação, assim como para a goiaba madura, a qual também apresentou uma pequena diminuição no teor de vitamina $\mathrm{C}$ na adubação máxima em relação as outras adubações.

Altas doses de adubação nitrogenada também provocaram uma diminuição no teor de vitamina C em sucos de laranja, limão, uva e tangerina (Nagy, 1980), assim como em outras culturas como a couve-flor (LISIEWSKA e KMIECIK, 1996). No entanto, em frutos do mamoeiro, o aumento da adubação nitrogenada não influenciou significativamente a variação de vitamina C (MARINHO et al., 2001).

Segundo Lee e Kader (2000), normalmente o crescimento da planta é reforçado pela adubação nitrogenada, portanto uma diluição relativa pode acontecer no tecido das plantas, e consequentemente uma diminuição no teor da vitamina. Além disso, o aumento da adubação 
nitrogenada geralmente aumenta a folhagem da planta diminuindo a intensidade da luz no fruto e consequentemente o acúmulo de AA.

Assim como para o ácido ascórbico, na última coleta a adubação $\mathrm{N}_{2}$ apresentou teores maiores do ácido desidroascórbico; no entanto esse valor não difere estatisticamente das demais adubações. $\mathrm{Na}$ terceira coleta $\mathrm{N}_{0}$ não apresentou níveis detectáveis do ácido, e $\mathrm{N}_{1}$ e $\mathrm{N}_{2}$ apresentaram valores superiores a $\mathrm{N}_{3}$.

Uma nova etapa de coletas foi realizada no intuito de verificar se os resultados obtidos para o primeiro conjunto de amostras (2010) foram influenciados pelo tempo de armazenamento. Para essa comparação, seria necessário que a coleta fosse realizada na mesma época (estação do ano) que a primeira coleta, no entanto, por razões temporais não foi possível realizar a nova coleta na mesma época do ano que a realizada em 2010. Foram realizadas apenas as coletas 3 e 4 nessa nova fase, uma vez que quando determinada a sua necessidade as amostras já se encontravam em estádio mais avançado, não permitindo coletas anteriores.

As amostras foram coletadas, armazenadas da mesma forma que as coletadas no primeiro período, no entanto foram analisadas rapidamente, não ficando estocadas por mais de uma semana. Os resultados obtidos para essa segunda fase de coletas estão apresentados na Tabela 19. 
Tabela 19 - Concentração do ácido ascórbico (AA), ácido ascórbico total (AA Total) e ácido desidroascórbico (DIA), segunda etapa de coletas, (média \pm desvio padrão) durante o desenvolvimento nas diferentes adubações.

\begin{tabular}{|c|c|c|c|c|c|}
\hline & \multirow{2}{*}{ Coletas 2012} & \multicolumn{4}{|c|}{ Adubaçãa } \\
\hline & & No & N1 & $\mathbf{N} 2$ & N3 \\
\hline \multirow{4}{*}{$\underset{\left(m g 100 g^{-1}\right)}{\mathbf{A A}}$} & Coleta 1 & nd & nd & nd & nd \\
\hline & Coleta 2 & nd & nd & nd & nd \\
\hline & Coleta 3 & $26,60^{\mathrm{aA}} \pm 1,53$ & $18,40^{\mathrm{bA}} \pm 1,22$ & $14,11^{\mathrm{cA}} \pm 0,23$ & $24,95^{\mathrm{dA}} \pm 2,34$ \\
\hline & Coleta 4 & $51,21^{\mathrm{aB}} \pm 1,26$ & $47,39^{\mathrm{bB}} \pm 0,23$ & $45,24^{\mathrm{cB}} \pm 0,34$ & $49,03^{\mathrm{dB}} \pm 0,78$ \\
\hline \multirow{4}{*}{$\begin{array}{l}\text { AA Total } \\
\left(\mathbf{m g} 100 \mathrm{~g}^{-1}\right)\end{array}$} & Coleta 1 & nd & nd & nd & nd \\
\hline & Coleta 2 & nd & nd & nd & nd \\
\hline & Coleta 3 & $28,93^{\mathrm{aA}} \pm 0,43$ & $25,27^{\mathrm{aA}} \pm 5,18$ & $14,44^{\mathrm{bA}} \pm 0,60$ & $42,62^{\mathrm{cA}} \pm 4,61$ \\
\hline & Coleta 4 & $53,61^{\mathrm{aB}} \pm 7,23$ & $63,73^{\mathrm{bB}} \pm 1,36$ & $64,26^{\mathrm{bB}} \pm 3,29$ & $69,92^{\mathrm{bB}} \pm 4,30$ \\
\hline \multirow{4}{*}{$\underset{\left({\mathrm{mg} 100 \mathrm{~g}^{-1}}^{-}\right)}{\text {DIA }}$} & Coleta 1 & nd & nd & nd & nd \\
\hline & Coleta 2 & nd & nd & nd & nd \\
\hline & Coleta 3 & $2,33^{\mathrm{abA}} \pm 1,16$ & $6,87^{\mathrm{aA}} \pm 4,31$ & $0,32^{\mathrm{bA}} \pm 0,49$ & $17,66^{\mathrm{cA}} \pm 6,30$ \\
\hline & Coleta 4 & $2,40^{\mathrm{aA}} \pm 8,27$ & $16,35^{\mathrm{bB}} \pm 1,33$ & $19,02^{\mathrm{bB}} \pm 3,37$ & $20,88^{\mathrm{bA}} \pm 3,61$ \\
\hline
\end{tabular}

Médias seguidas pela mesma letra ( $a, b, c$ e d) na linha não diferem entre si em relação à adubação pelo teste ANOVA, com 95\% de significância $(0,05)$. Médias seguidas pela mesma letra (Ae B) na coluna não difere entre si em relação aos estádios de desenvolvimento pelo teste ANOVA, com $95 \%$ de significância $(0,05)$.

Na Figura 21 é possível observar o comportamento das amostras provenientes da nova etapa de coletas. Assim como na primeira etapa de coletas, as amostras demonstraram um aumento do teor de ácido ascórbico com o desenvolvimento do fruto para todas as adubações. 
Figura 21 - Variação do ácido ascórbico (a) e ácido ascórbico total (b) em relação ao estádio de desenvolvimento nas quatro diferentes adubações.
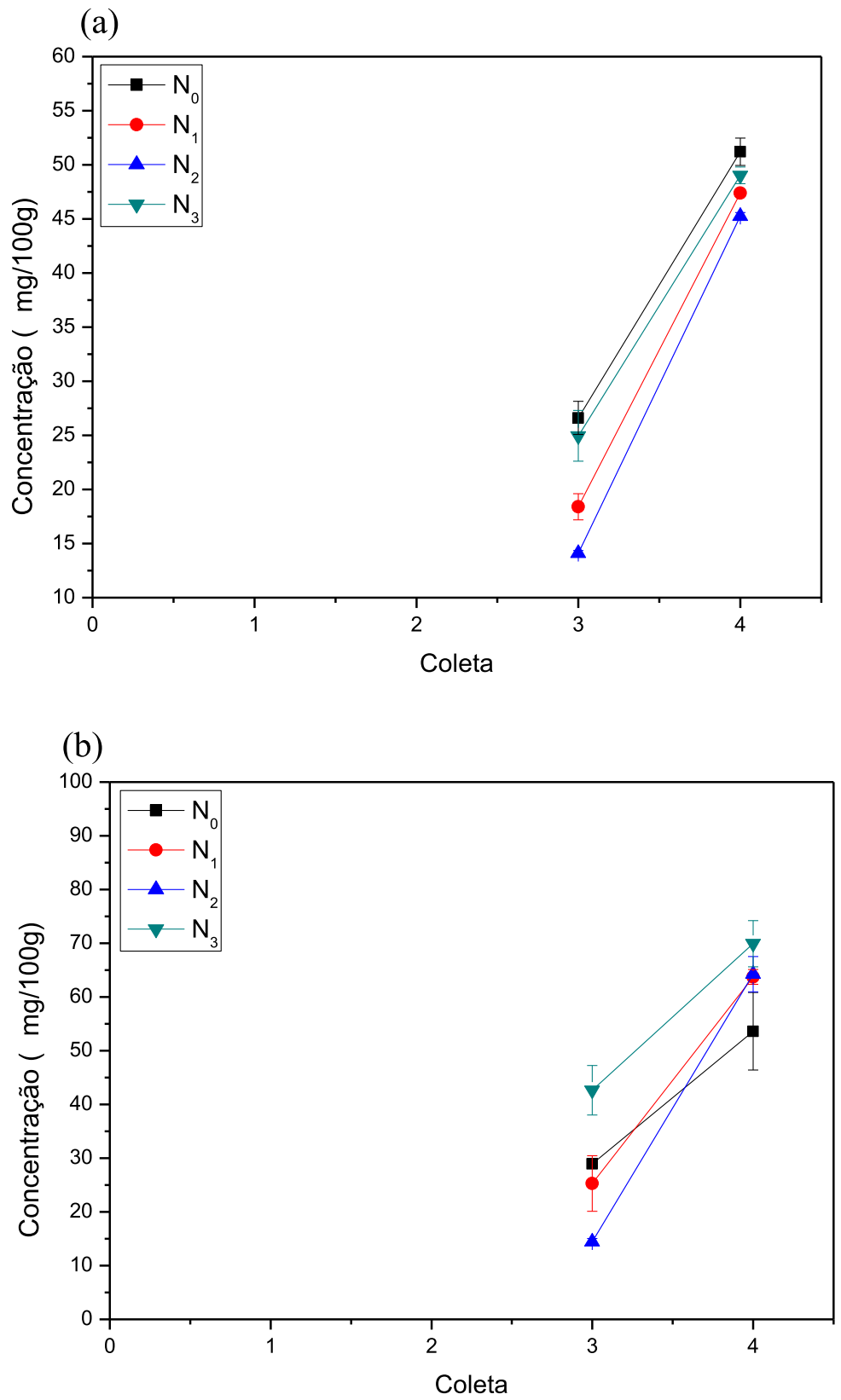

Da mesma forma que para as amostras da primeira etapa, houve um aumento do teor de ácido ascórbico com o desenvolvimento do fruto para todas as adubações, sendo que a variação entre os dois estádios de desenvolvimento foi significativa estatisticamente. $\mathrm{O}$ ácido desidroascórbico apresentou um aumento, concordando com o observado na primeira etapa de coletas, no entanto essa variação foi significativa apenas para as amostras $\mathrm{N}_{1}$ e $\mathrm{N}_{2}$, como pode ser observado na Figura 22. 
Figura 22 - Variação do ácido desidroascórbico em relação ao estádio de desenvolvimento nas quatro diferentes adubações.

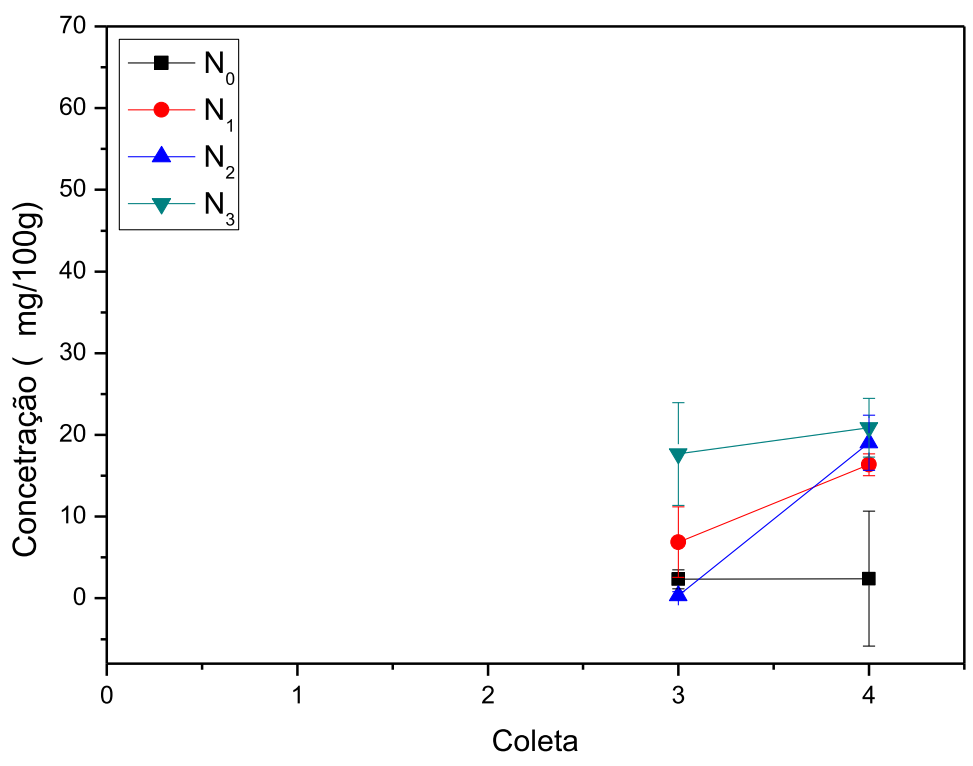

No geral, foi possível observar que em ambas as etapas de coleta (2010 e 2012), as amostras apresentaram um aumento no teor dos ácidos com o desenvolvimento. Como discutido anteriormente, este comportamento também já foi observado por outros autores para goiaba e outras frutas, mas NAGY (1980) observou que durante o amadurecimento, ocorre uma diminuição da vitamina $\mathrm{C}$ em laranja, uva e tangerina.

Em relação à adubação, ao contrário do que foi observado nas amostras da primeira etapa de coletas, a adubação $\mathrm{N}_{2}$ apresentou teores menores de ácido ascórbico, sendo que na ausência de adubação e na adubação máxima foram observados valores maiores.

Em relação ao ácido ascórbico total, a amostra $\mathrm{N}_{2}$ da coleta 3 apresentou uma diferença mais pronunciada em relação as demais adubação. Na coleta 4 houve um aumento do teor de ácido ascórbico com a adubação nitrogenada, ao contrário do que foi observado para primeira etapa de coletas. Vale ressaltar que a determinação do ácido ascórbico total depende da redução do ácido desidroascórbico a ácido ascórbico pela ação da cisteína, portanto, os valores obtidos podem ser influenciados pela eficiência dessa reação.

Para o ácido desidroascórbico, foi possível observar que na coleta 3 houve uma diminuição do ácido com adubação $\mathrm{N}_{2}$, mas na fruta madura o aumento da adubação nitrogenada levou a um aumento no teor do ácido. De acordo com os resultados obtidos, as amostras se comportaram de forma diferente nas duas etapas de coletas em relação à adubação. Na primeira etapa o aumento da adubação nitrogenada provocou uma diminuição no teor de ácido ascórbico, principalmente comparando as adubações $\mathrm{N}_{2}$ e $\mathrm{N}_{3}$, sendo que $\mathrm{N}_{2}$ 
apresentou teores mais elevados. Já nessa nova etapa foi observado o contrário, discordando também de outros trabalhos citados anteriormente, nos quais observou-se diminuição da vitamina $\mathrm{C}$ com o aumento da adubação nitrogenada.

Comparando as duas fases de coletas, apresentadas na Figura 23, as amostras coletadas em 2012 apresentaram maiores teores de ácido ascórbico em relação ao primeiro período, com exceção da adubação $\mathrm{N}_{2}$ na coleta 3 .

Figura 23 - Comparação do teor de ácido ascórbico entre a primeira (2010) e segunda (2012) etapa de coletas, para as coletas (a) 3 e (b) 4 .

(a)

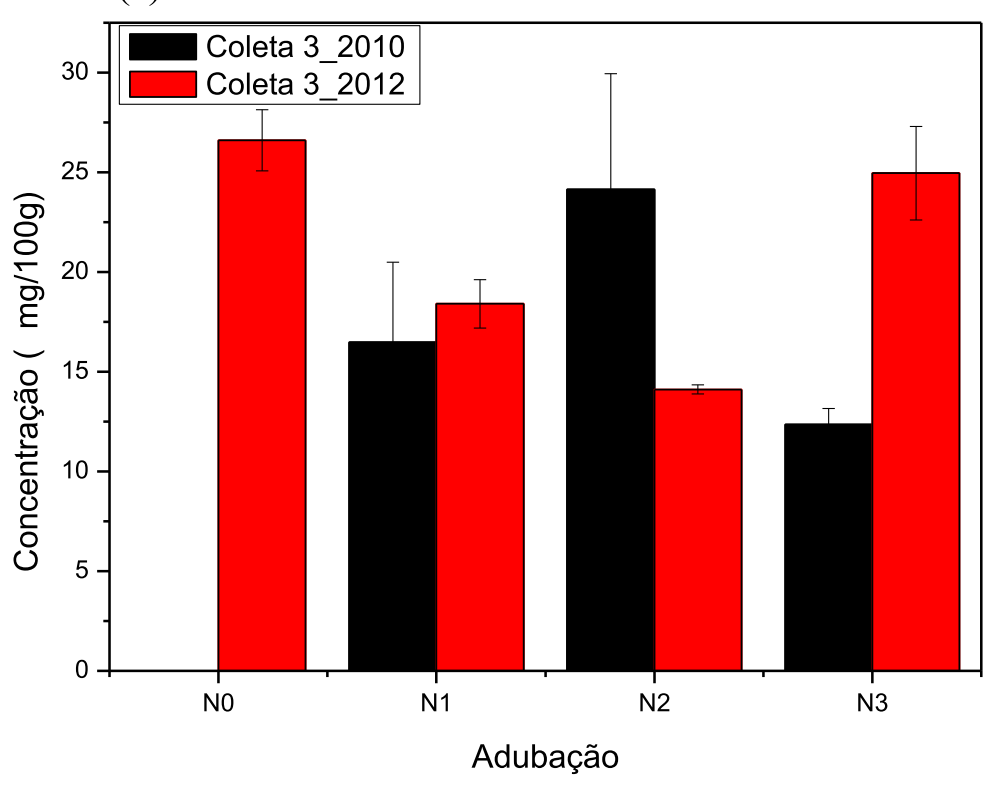

(b)

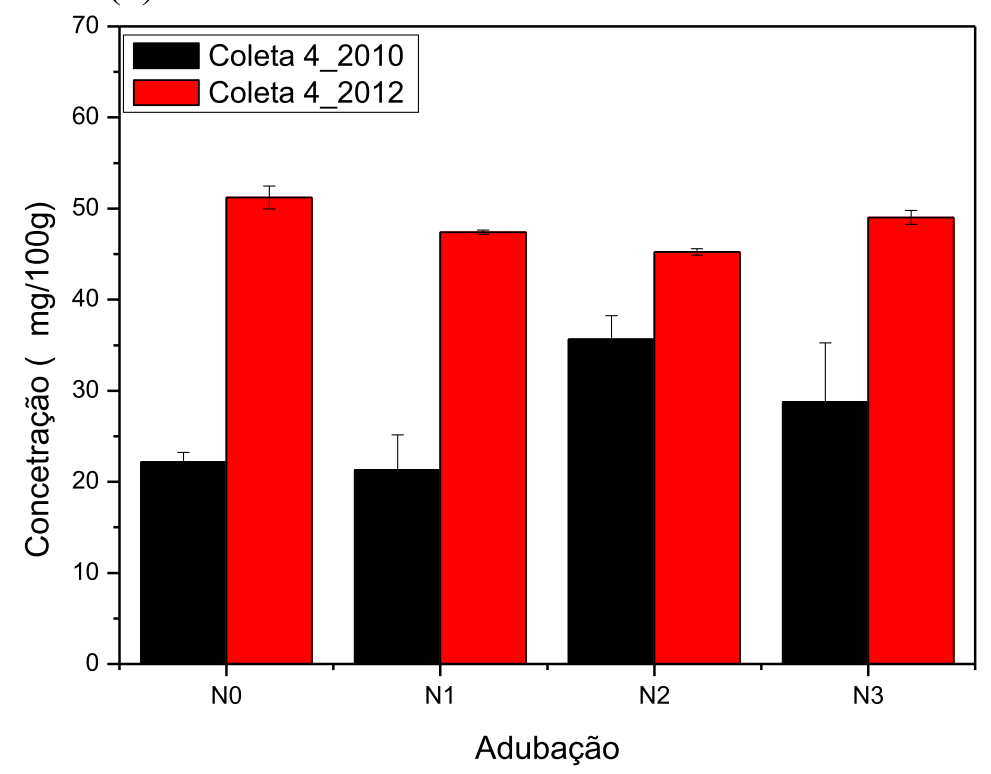

Em relação ao ácido ascórbico total, na coleta 3 foi observada uma maior concentração nas amostras $\mathrm{N}_{1}$ e $\mathrm{N}_{2}$ de 2010. Já as amostras maduras (coleta 4) de 2012 apresentaram maior 
teor da vitamina para todas as adubações, sendo que a diferença encontrada entre as duas épocas de coleta para adubação $\mathrm{N}_{2}$ foi muito pequena, como pode ser visto na Figura 24 .

Figura 24 - Comparação do teor de ácido ascórbico total entre a primeira (2010) e segunda (2012) etapas de coletas, para as coletas 3 (a) e 4 (b).

(a)

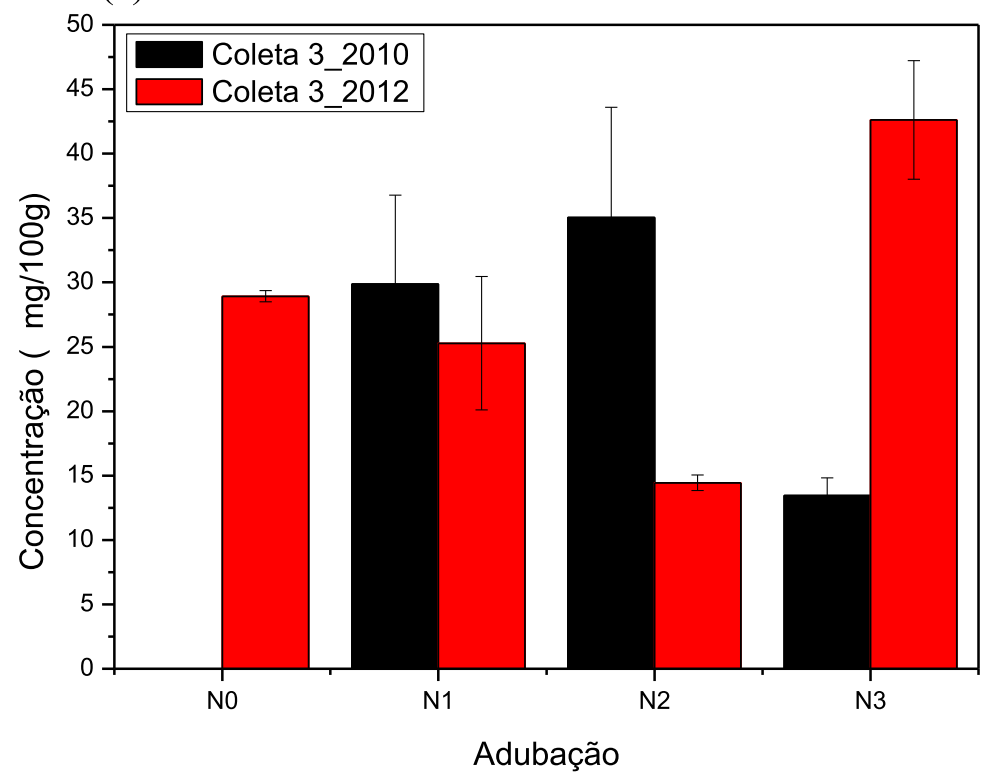

(b)

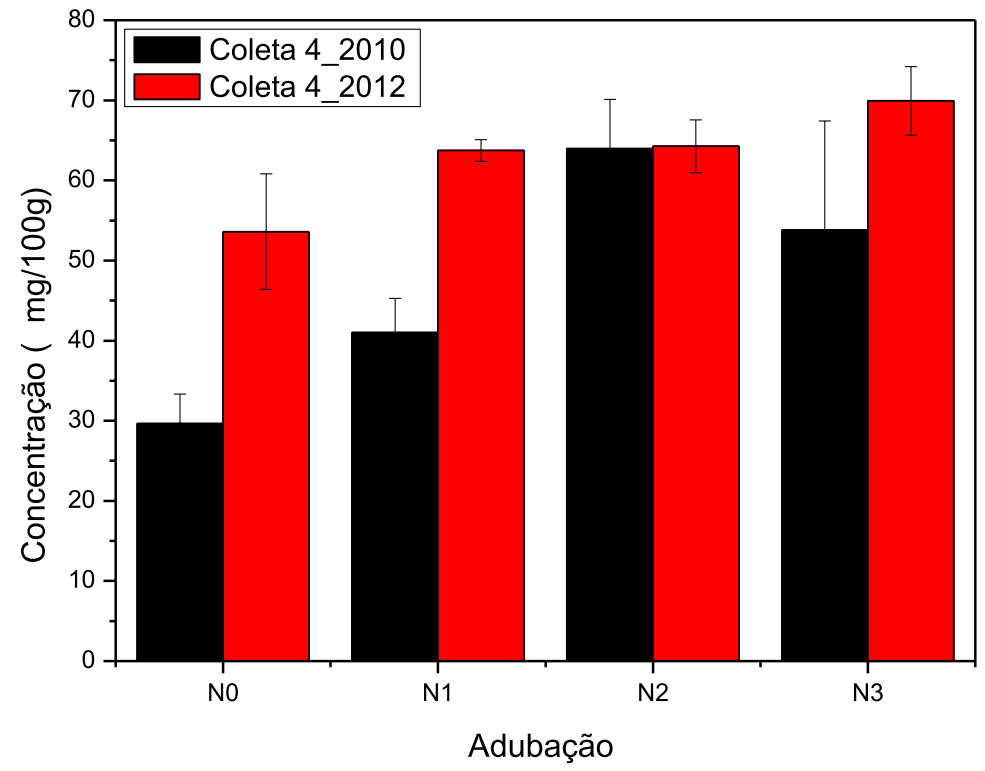

Nas coletas de 2012 as amostras $\mathrm{N}_{1}$ e $\mathrm{N}_{2}$ da coleta 3 e todas as amostras da coleta 4 apresentaram menores teores do ácido desidroascórbico em relação as coletas de 2010, como pode ser visto na Figura 25. 
Figura 25 - Comparação do teor de ácido desidroascórbico entre a primeira (2010) e segunda (2012) etapa de coletas, para as coletas 3 (a) e 4 (b).

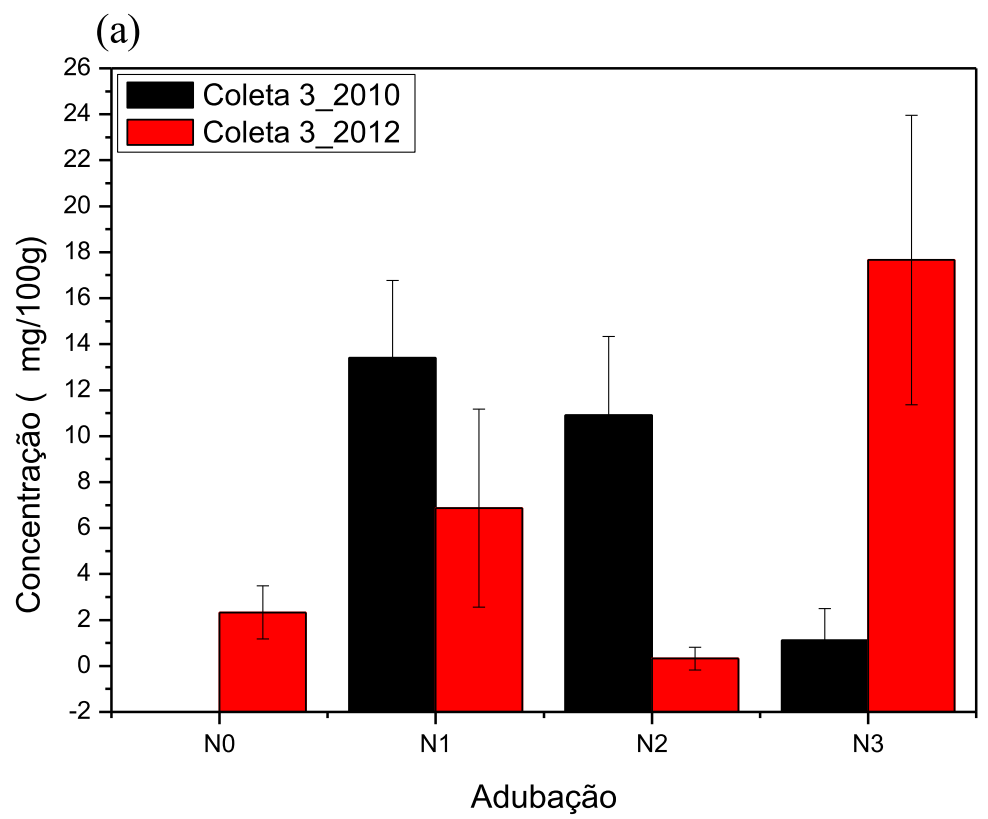

(b)

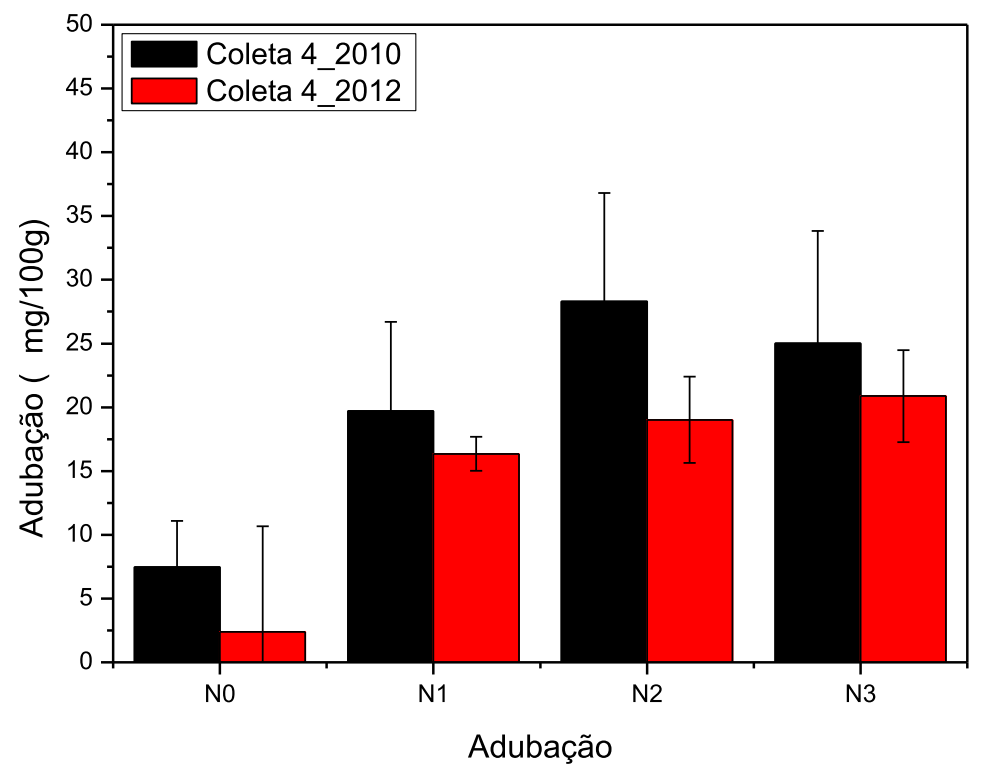

Uma vez que as coletas foram realizadas em épocas do ano diferentes, primeira etapa de coletas entre os meses de abril-julho (inverno) e segunda etapa entre os meses de janeirofevereiro (verão), não se pode afirmar que o tempo de estocagem ocasionou menores valores no primeiro período em relação ao segundo. Segundo Nagy (1980), o teor de vitamina C pode ser influenciado pelo clima e quantidade de luz com que a planta fica em contato durante o seu desenvolvimento, por isso a estação do ano em que ela se desenvolveu pode ter afetado os valores determinados.

Lee e Kader (2000) afirmam que embora a luz não seja essencial para a síntese de 
ácido ascórbico nas plantas, a quantidade e intensidade de luz com que a fruta tem contato durante o crescimento tem grande influência no teor de ácido ascórbico formado, assim como a temperatura (LEE e KADER, 2000). Portanto, ainda que comparadas as duas coletas, não se pode afirmar que a diferença entre as duas está relacionada apenas com o tempo que as amostras coletadas em 2010 ficaram estocadas antes de serem analisadas.

\subsubsection{Carotenoides majoritários}

\subsubsection{Extração dos carotenoides}

O método utilizado para extração já foi descrito anteriormente, no entanto vale ressaltar, que a extração é uma das etapas mais importantes na análise de carotenóides, pois nessa etapa pode ocorrer degradação. Por esta razão todo o processo de extração foi realizado de forma a evitar o máximo possível o contato com a luz, e para isso foi necessário a utilização de papel alumínio para o recobrimento de vidraria e a utilização de frascos âmbar. Além disso, em diferentes etapas foi feito o uso de nitrogênio para diminuir o contato das amostras com o oxigênio. A rotoevaporação das amostras foi realizada de forma cautelosa, para que a temperatura não atingisse valores maiores que $35^{\circ} \mathrm{C}$, uma vez que altas temperaturas levam a degradação dos carotenóides (RODRIGUEZ-AMAYA, 1997).

Segundo Gonzáles et al. (2011), não há a necessidade da saponificação das amostras de carotenóides provenientes da goiaba, uma vez que não há evidências de altas quantidades de ésteres de carotenóides na fruta, dessa forma essa etapa não foi realizada nos nossos experimentos.

\subsubsection{Separação e identificação dos carotenoides por cromatografia líquida de alta eficiência (HPLC)}

Para quantificação do betacaroteno foi utilizado padrão para construção de uma curva de calibração, sendo que a equação da reta obtida, coeficiente de correlação, limites de detecção e quantificação e faixa de concentração estudada, encontram-se na Tabela 20. 
Tabela 20 - Equação de regressão linear, coeficiente de correlação, limite de detecção (LD), limite de quantificação (LQ) e faixa de concentração estudada para o betacaroteno.

\begin{tabular}{|c|c|c|c|c|c|}
\hline Carotenóide & $\begin{array}{c}\text { Equação da reta } \\
\mathbf{Y}=\mathbf{A}+\mathbf{B X}\end{array}$ & $\begin{array}{c}\text { Coeficiente } \\
\text { de correlação }\end{array}$ & $\begin{array}{c}\text { LD } \\
\left(\mu \mathrm{g} \mathbf{m L}^{-1}\right)\end{array}$ & $\begin{array}{c}\mathbf{L Q} \\
\left(\mu \mathrm{g} \mathrm{mL} \mathbf{L}^{-1}\right)\end{array}$ & $\begin{array}{c}\text { Faixa } \\
\text { estudada } \\
\left(\mu \mathrm{g} \mathrm{mL} L^{-1}\right)\end{array}$ \\
\hline Betacaroteno & $\mathrm{Y}=198141,69+5425,85 * \mathrm{X}$ & 0,995 & 50,14 & 167,14 & $80-800$ \\
\hline
\end{tabular}

$\mathrm{LD}=\frac{\mathrm{DPa} \times 3}{\mathrm{IC}} ; \mathrm{LQ}=\frac{\mathrm{DPa} \times 10}{\mathrm{IC}}$

O coeficiente de correlação obtido para o método na faixa de concentração descrita acima foi de 0,9953 , e os valores de LD e LQ foram determinados segundo a ANVISA (ANVISA, 2003).

$\mathrm{Na}$ Tabela 21, pode-se ver os resultados obtidos para repetibilidade e precisão intermediária do método. Para isso foi utilizada uma solução padrão de betacaroteno $100 \mu \mathrm{g}$ $\mathrm{mL}^{-1}$, e foram feitas seis injeções consecutivas durante um dia e três injeções consecutivas durante três dias para avaliar repetibilidade e precisão entre dias, respectivamente, enquanto que na Figura 26 é possível observar os cromatogramas referentes à uma amostra e padrão de betacaroteno.

Tabela 21 - Precisão do método para análises intra-dia e entre-dias de carotenoides.

\begin{tabular}{c|cc|cc}
\hline \multirow{2}{*}{ Carotenóide } & \multicolumn{2}{|c|}{ Repetibilidade $(\mathbf{n}=\mathbf{6})$} & \multicolumn{2}{c}{$\begin{array}{c}\text { Precisão Intermediária } \\
(\mathbf{n}=\mathbf{9}) *\end{array}$} \\
\cline { 2 - 5 } & $\begin{array}{c}\mathrm{CV}(\%) \\
\text { tempo de eluição }\end{array}$ & $\begin{array}{c}\mathrm{CV}(\%) \\
\text { área de pico }\end{array}$ & $\begin{array}{c}\mathrm{CV}(\%) \\
\text { tempo de eluição }\end{array}$ & $\begin{array}{c}\mathrm{CV}(\%) \\
\text { área de pico }\end{array}$ \\
\hline \multirow{2}{*}{ Betacaroteno } & 0,43 & 5,00 & 3,10 & 6,00 \\
\hline
\end{tabular}


Figura 26 - Cromatograma referente ao padrão de betacaroteno e a uma amostra.

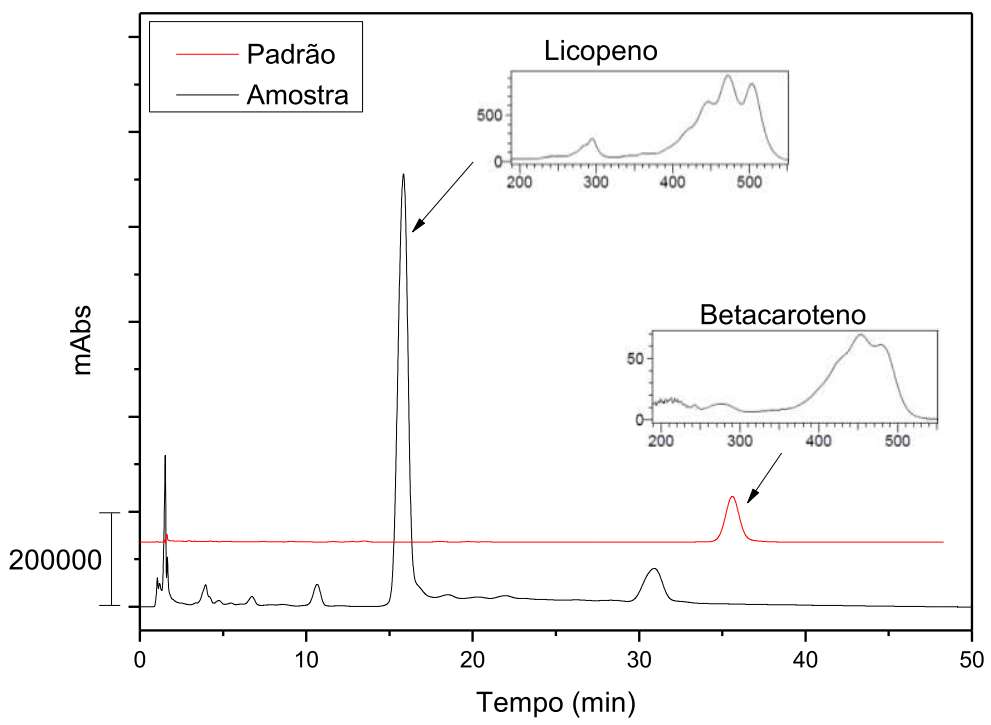

Como pode ser observado, foi possível identificar o betacaroteno nas amostras $\operatorname{com} \lambda$ máx de $450 \mathrm{~nm}$, assim como o licopeno em $470 \mathrm{~nm}$, os espectros correspondentes a cada pico foram obtidos pelo software do equipamento de cromatografia líquida. Devido a variação do tempo de eluição foi necessário a adição de padrão de betacaroteno à amostra para cofirmação do seu pico. Na quantificação do betacaroteno obtiveram-se os valores apresentados na Tabela 22.

Tabela 22 - Concentração do betacaroteno (média \pm desvio padrão) durante o desenvolvimento nas diferentes adubações.

\begin{tabular}{|c|c|c|c|c|c|}
\hline & \multirow{2}{*}{ Coletas 2010} & \multicolumn{4}{|c|}{ Adubação } \\
\hline & & No & N1 & $\mathbf{N 2}$ & $\mathbf{N 3}$ \\
\hline \multirow{4}{*}{$\begin{array}{c}\text { Betacaroteno } \\
\left(\mu{\left.\mathrm{g} 100 \mathrm{~g}^{-1}\right)}^{-1}\right.\end{array}$} & Coleta 1 & - & - & - & - \\
\hline & Coleta 2 & $7796,99^{\mathrm{aA}} \pm 28,03$ & $6788,98^{\mathrm{bA}} \pm 39,77$ & $2815,31^{\mathrm{cA}} \pm 463,02$ & $8616,47^{\mathrm{dA}} \pm 76,16$ \\
\hline & Coleta 3 & $699,41^{\mathrm{aB}^{\mathrm{B}}}+28,82$ & $1137,85^{\mathrm{bB}_{ \pm}} 92,50$ & $3270,46^{\mathrm{cA}} \pm 108,17$ & $1852,30^{\mathrm{dB}} \pm 19,30$ \\
\hline & Coleta 4 & $1107,47^{\mathrm{aC}} \pm 2,49$ & $14246,67^{\mathrm{b} C} \pm 273,89$ & $18690,87^{\mathrm{cC}} \pm 329,96$ & $2705,29^{\mathrm{dC}} \pm 783,96$ \\
\hline
\end{tabular}

Médias seguidas pela mesma letra $(\mathrm{a}, \mathrm{b}, \mathrm{c}$ e d) na linha não diferem entre si em relação à adubação pelo teste ANOVA, com $95 \%$ de significância $(0,05)$. Médias seguidas pela mesma letra (A e B) na coluna não difere entre si em relação aos estádios de desenvolvimento pelo teste ANOVA, com 95\% de significância $(0,05)$.

Com exceção das amostras $\mathrm{N}_{2}$ nas coletas 2 e 3, todos os demais valores diferem significativamente entre si. Como pode ser observado na goiaba madura (coleta 4), o maior teor de betacaroteno foi encontrado para amostra $\mathrm{N}_{2}$, valor maior que o encontrado para goiabas de Israel que foram de 4960,00 $\mu \mathrm{g} 100 \mathrm{~g}^{-1}$ (BEM-AMOTZ e FISHLER, 1998), da Indonésia de $984 \mu \mathrm{g} 100 \mathrm{~g}^{-1}$ (SETIAWAN et al., 2001) e goiaba brasileira cv. Palmira ICA-1 
de $155 \mu \mathrm{g} 100 \mathrm{~g}^{-1}$ (GONZÁLEZ et al., 2011). Na Figura 27é possível observar a variação da concentração do betacaroteno em relação às coletas para as diferentes adubações.

Em geral nas goiabas, assim como em outras frutas, é observado um aumento dos carotenóides totais com a maturação, na qual ocorre mudança na pigmentação, facilitando a discriminação visual das frutas. Segundo Jain et al. (2003) concomitante ao aumento dos carotenóides ocorre a diminuição na clorofila, o que pode ser observado visualmente pela mudança da cor verde para amarelada (JAIN, et al., 2003; OLIVEIRA et al., 2006; RODRIGUEZ-AMAYA, 1997). Assim como as goiabas, vegetais folhosos maduros tendem a apresentar maiores níveis de carotenóides como betacaroteno em relação com folhas jovens (HULSHOF et al., 1997).

Figura 27 - Variação do betacaroteno em relação ao estádio de desenvolvimento nas quatro diferentes adubações.

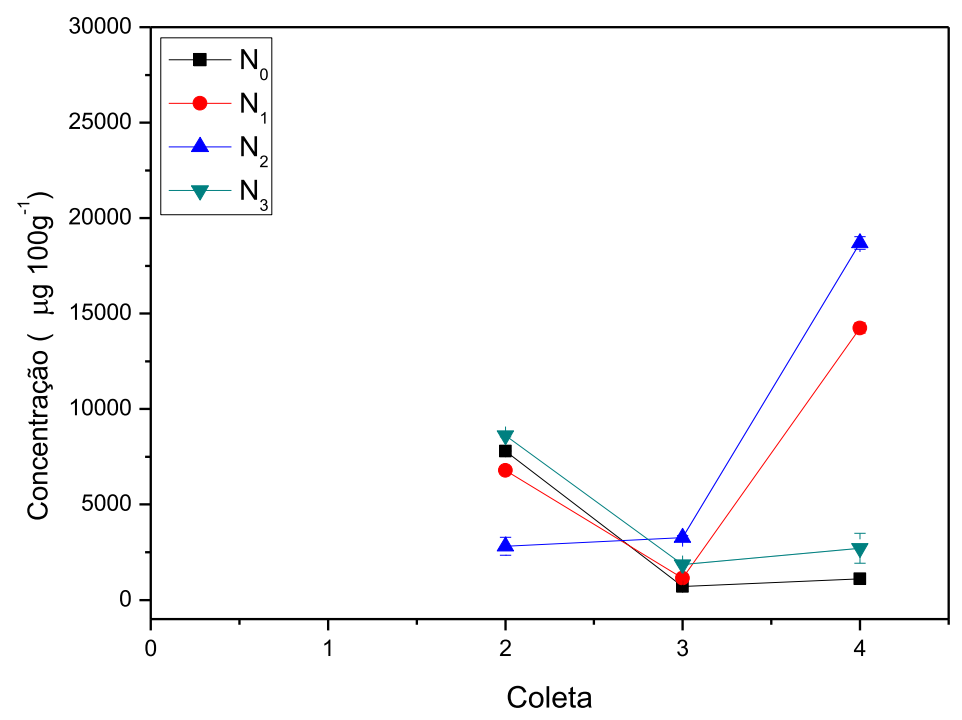

Pelo gráfico da Figura 27 é possível observar que para as amostras $\mathrm{N}_{0}$ e $\mathrm{N}_{3}$ a concentração do betacaroteno diminui na coleta 3, tendo um ligeiro aumento na coleta 4. Já a amostra $\mathrm{N}_{1}$ também apresentou uma diminuição na coleta 3, no entanto um aumento considerável na coleta 4 , enquanto que a amostra $\mathrm{N}_{2}$ apresentou um aumento na concentração com o decorrer das coletas.

No trabalho de González et al. (2011) com goiabas cv. Regional roja, Regional blanca e Palmira (IAC-1), apenas a cv. Palmira apresentou níveis detectáveis de betacaroteno, sendo que assim como foi observado nesse trabalho para algumas adubações, houve uma ligeira diminuição no estádio intermediário de desenvolvimento, com aumento da concentração nas amostras da última coleta. 
$\mathrm{Na}$ coleta 2, a adubação $\mathrm{N}_{2}$ demonstrou uma maior diminuição e relação às demais adubações, ao contrário das demais coletas, nas quais $\mathrm{N}_{2}$ apresentou maiores teores. $\mathrm{O}$ excesso da adubação nitrogenada $\mathrm{N}_{3}$ promoveu uma diminuição do teor de betacaroteno, com valores próximos aos encontrados para amostras sem adubação.

Não foi encontrado na literatura relação da adubação nitrogenada com o teor de betacaroteno, o que mostra a contribuição inédita deste trabalho, assim como das pectinas.

Com já foi dito anteriormente, a concentração e composição dos carotenóides nas frutas pode ser influenciada por diferentes fatores, como condições de desenvolvimento, amadurecimento, cultivar, assim como localidade geográfica e estação do ano em que se desenvolveu (ASSUNÇÃO e MERCADANTE, 2003; SETIAWAN et al., 2001). Com isso, as amostras de goiaba madura da coleta realizada em 2010 (maio - julho) foram comparadas as da coleta realizada em 2012 (fevereiro - março), e os resultados são apresentados na Figura 28.

Figura 28 - Comparação do teor de betacaroteno em amostras de goiaba nas diferentes adubações em relação à época da coleta: coleta 2010 (inverno) e coleta 2012 (verão).

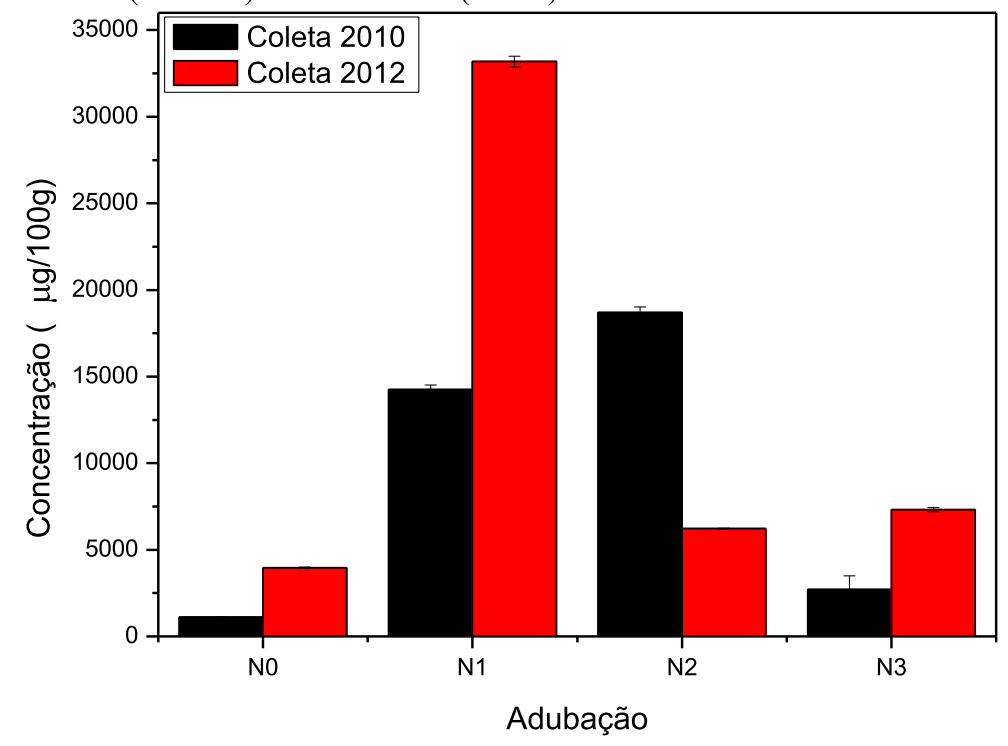

As amostras coletadas em 2012 apresentaram maior teor de betacaroteno em relação à coleta de 2010, com exceção da amostra $\mathrm{N}_{2}$. Além disso, ao contrário do que foi observado para coleta de 2010, as goiabas maduras apresentaram maior concentração de betacaroteno nas amostras $\mathrm{N}_{1}$, seguida por $\mathrm{N}_{3}, \mathrm{~N}_{2}$ e $\mathrm{N}_{0}$.

Segundo Azevedo e Rodriguez-Amaya (2005), as frutas expostas ao sol e a altas temperaturas durante seu desenvolvimento tem o aumento da biossíntese dos carotenóides, no entanto também sofrem a fotodegradação. Possivelmente o processo de degradação nas 
amostras $\mathrm{N}_{2}$ na coleta de 2012 foi maior que a biossíntese, ao contrário do observado para as outras amostras.

Além do betacaroteno, outros trabalhos destacam o licopeno como um dos principais carotenóides presentes na goiaba. Três variedades de goiabas colombianas foram estudadas, sendo que o licopeno foi identificado como o maior carotenóide presente nas cultivares maduras de Regional roja e Palmira ICA-1 (GONZÁLEZ et al., 2011), assim como para goiaba vermelha Brasileira estudada por diferentes autores (MERCADANTE, STECK e PFANDER, 1999; PADULA e RODRÍGUEZ-AMAYA, 1986). Já em um trabalho realizado com goiabas da Indonésia, licopeno e betacaroteno foram encontrados em quantidades similares (SETIAWAN et al., 2001).

Neste trabalho não foi possível realizar a quantificação do teor de licopeno, no entanto seu perfil em relação ao desenvolvimento do fruto e a variação das doses de adubação nitrogenada foram estudados utilizando a área dos picos obtidos por cromatografia líquida (Figura 29).

Figura 29 - Variação do licopeno em relação ao estádio de desenvolvimento nas quatro diferentes adubações.

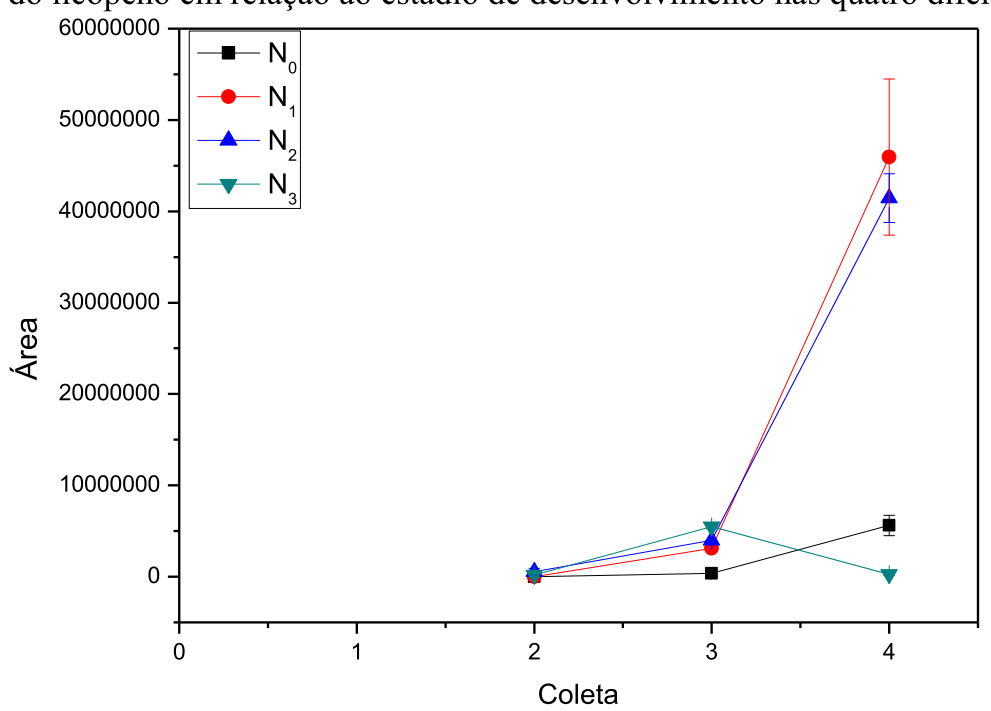

Pode-se verificar um aumento no teor de licopeno na goiaba madura em relação às duas coletas anteriores, principalmente para as amostras $\mathrm{N}_{1}$ e $\mathrm{N}_{2}$. A amostra $\mathrm{N}_{0}$ também apresentou um aumento, no entanto muito menor que para as duas amostras citadas anteriormente. Já a amostra $\mathrm{N}_{3}$ apresentou um pequeno decréscimo de licopeno com a maturação. 
Em relação à adubação, entre as amostras maduras $\mathrm{N}_{1}$ foi a adubação que apresentou aumento do licopeno, já na coleta anterior foi $\mathrm{N}_{3}$. Não foi encontrada na literatura a influência da adubação nitrogenada na síntese de licopeno pela fruta.

\subsection{Análise de Componentes Principais (PCA)}

Todos os resultados obtidos (com exceção dos açúcares neutros presentes na pectina e licopeno) foram analisados por Análise de Componentes Principais (PCA) com a finalidade de observar se existe um padrão de agrupamento entre as goiabas coletadas nas diferentes épocas e goiabas provenientes das diferentes doses de adubação. A Figura 30 apresenta os resultados de PCA para goiaba nas diferentes coletas, e para as diferentes adubações.

Figura 30 - Gráficos de scores (a) para coleta $\left(\mathrm{C}_{1}-1, \mathrm{C}_{2}-2, \mathrm{C}_{3}-3\right.$ e $\left.\mathrm{C}_{4}-4\right)$ e (b) adubação $\left(\mathrm{N}_{0}-1 ; \mathrm{N}_{1}-2 ; \mathrm{N}_{2}-3\right.$; $\left.\mathrm{N}_{3}-4\right)$ e (c) gráfico de loadings.

(a)

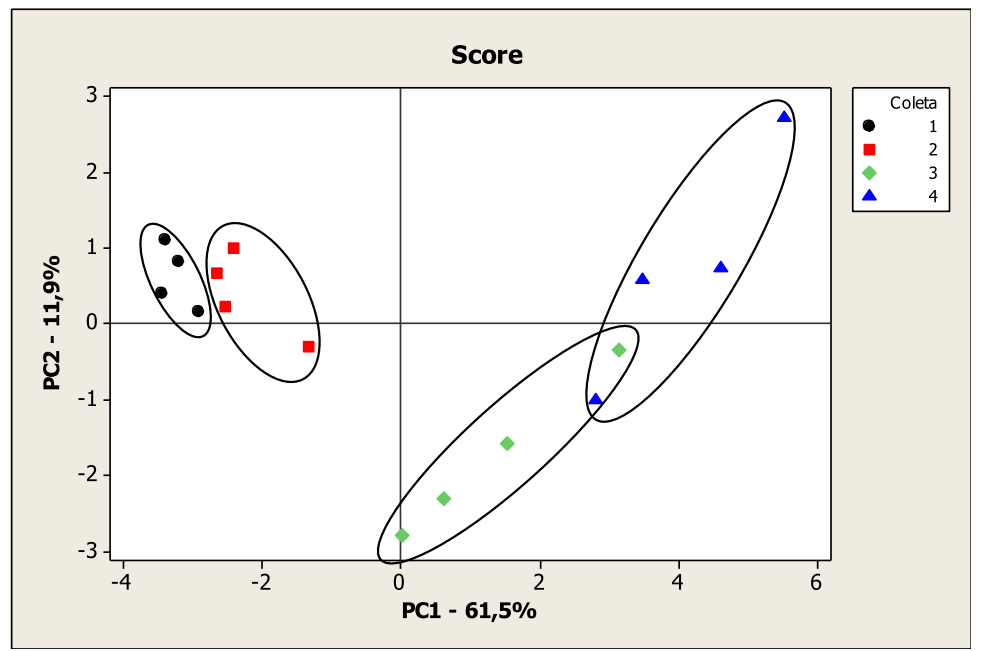

(b)

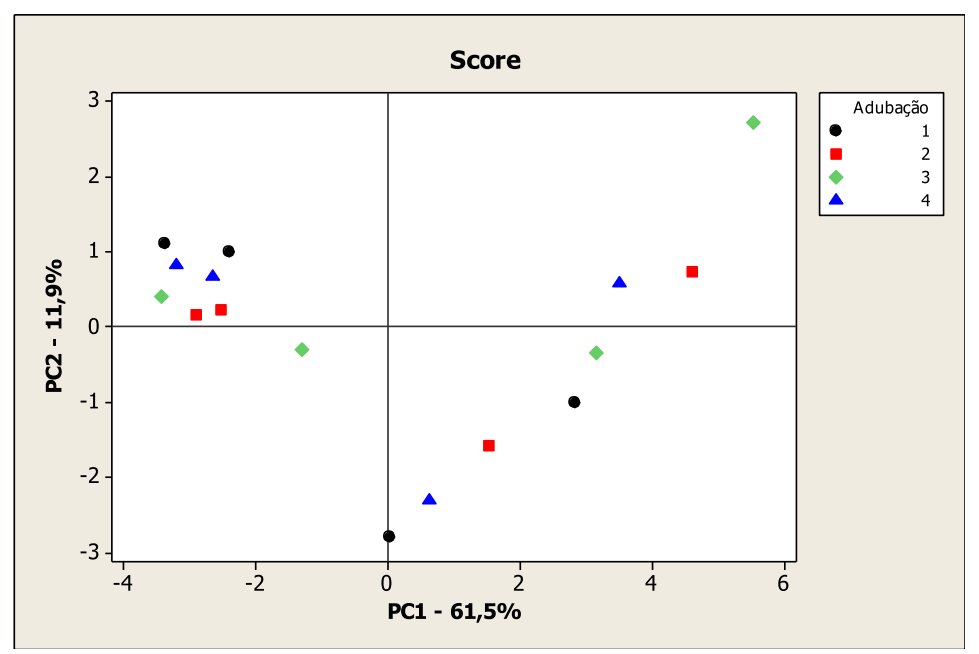


(c)

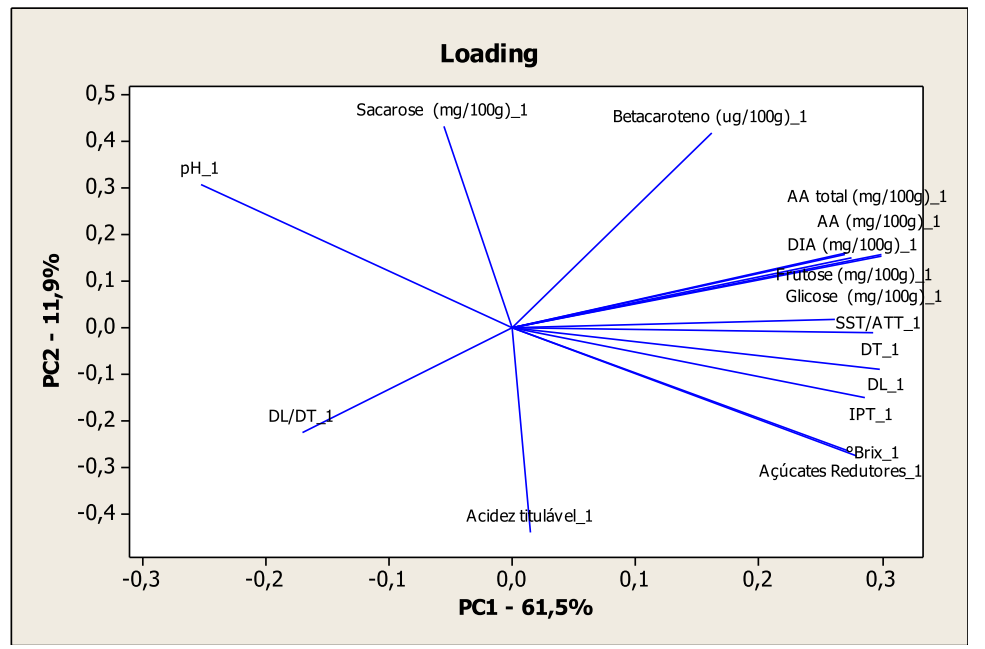

Considerando as diferentes coletas, correspondentes a diferentes estádios de maturação, é possível observar pelo gráfico de scores a formação de quatro grupos. Dois grupos próximos, porém distintos, referentes às amostras das coletas 1 e $2\left(\mathrm{C}_{1}\right.$ e $\left.\mathrm{C}_{2}\right)$, e outros dois grupos distantes de $\mathrm{C}_{1}$ e $\mathrm{C}_{2}$, no entanto próximos entre si, correspondentes às coletas $\mathrm{C}_{3} \mathrm{e}$ $\mathrm{C}_{4}$. A formação destes grupos nos permite afirmar que o conjunto de variáveis é capaz de diferenciar as coletas, e portanto os estádios de desenvolvimento dos frutos, com base nas variáveis analisadas. No entanto entre as coletas $\mathrm{C}_{3}$ e $\mathrm{C}_{4}$ duas amostras não se distinguem em seus grupos, sendo elas $\mathrm{N}_{0}-\mathrm{C}_{4}$ e $\mathrm{N}_{2}-\mathrm{C}_{3}$, nas quais a adubação influenciou o agrupamento da amostra considerando a coleta. Em geral $\mathrm{N}_{0}$ apresentou valores mais próximos da coleta anterior para a maioria das variáveis estudadas, o que pode ser atribuído ao fato da amostra estar próxima do grupo da coleta 3.

Diferentemente das coletas, a adubação não proporcionou a formação de grupos distintos, indicando que cada variável foi influenciada diferentemente por cada nível de adubação.

Segundo Matos et al, (2003) os gráficos de scores e loadings devem ser analisados em conjunto, uma vez que o gráfico de scores representa a distribuição das amostras de acordo com as variáveis, representadas pelo gráfico de loadings. Como foi discutido acima, em relação à adubação pouco se conclui dos resultados. No entanto, considerando o desenvolvimento do fruto, ao sobrepor os gráficos de scores e loadings, pode-se observar que a separação das duas primeiras coletas sofreram grande influência do $\mathrm{pH}$, agrupando-se na região de maior pH. Já as variáveis como açúcares, ${ }^{\circ}$ Brix e ácido ascórbico apresentaram maior influência na separação das duas últimas coletas, as quais se agrupam nessa região. Nesse conjunto de dados, a componente principal 1 (PC1) explica 61,2\% da variância dos 
dados originais, e a componente principal 2 (PC2) 11,9\%, enquanto que as demais PCs explicam muito pouco dos dados originais, possibilitando reduzir a dimensão dos dados de 18 variáveis para 2 .

Levando em conta o gráfico de loadings para todas as variáveis percebeu-se que muitas são as variáveis responsáveis pela separação das duas últimas coletas. Desta forma foi realizado um levantamento para descriminar quais variáveis influenciam mais significativamente os estágios finais. Pode-se ver que as análises clássicas, como diâmetros, ${ }^{\circ}$ Brix, açúcares redutores entre outras foram as que mais influenciaram.

Na Figura 31, pode-se visualizar a PCA realizada para 9 variáveis, sendo elas diâmetros longitudinal e transversal, relação DL/DT, açúcares redutores, $\mathrm{pH},{ }^{\circ} \mathrm{Brix}$, índice de polifenóis totais (IPT), acidez titulável e relação SST/ATT (sólidos solúveis totais/acidez titulável total). A PC1 explica $66,4 \%$ da variância dos dados originais, e a PC2 14,1\%, representando $80,5 \%$ da variância total.

Figura 31 - Gráficos de scores (a) para coleta e (b) adubação $\left(\mathrm{N}_{0}-1 ; \mathrm{N}_{1}-2 ; \mathrm{N}_{2}-3 ; \mathrm{N}_{3}-4\right)$ e (c) gráfico de loadings, para análises básicas.

(a)

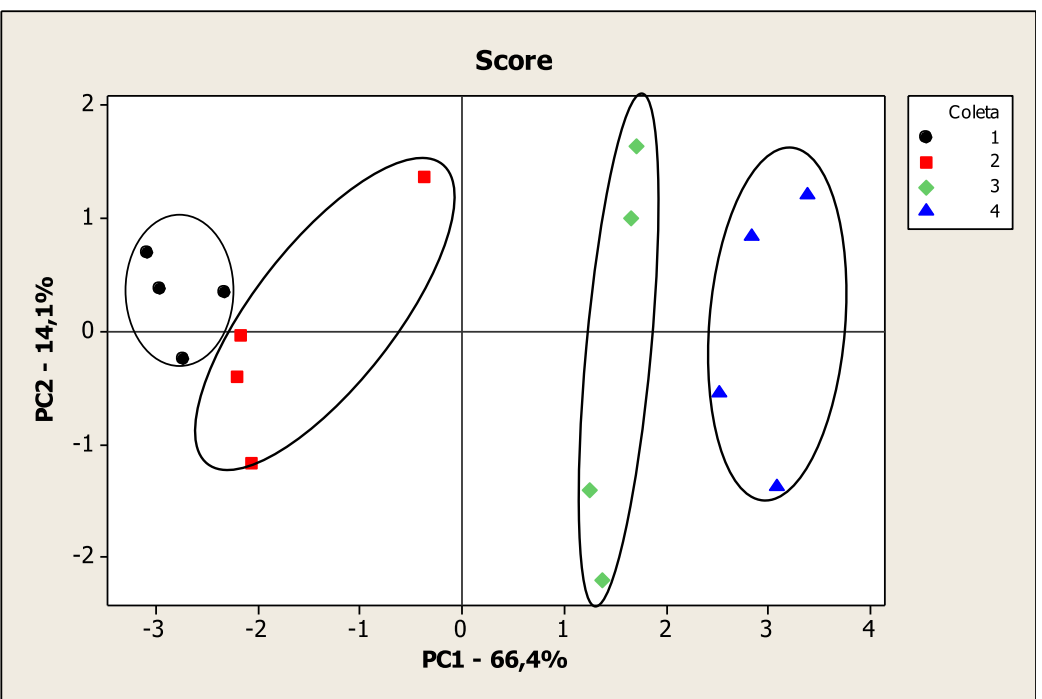


(b)

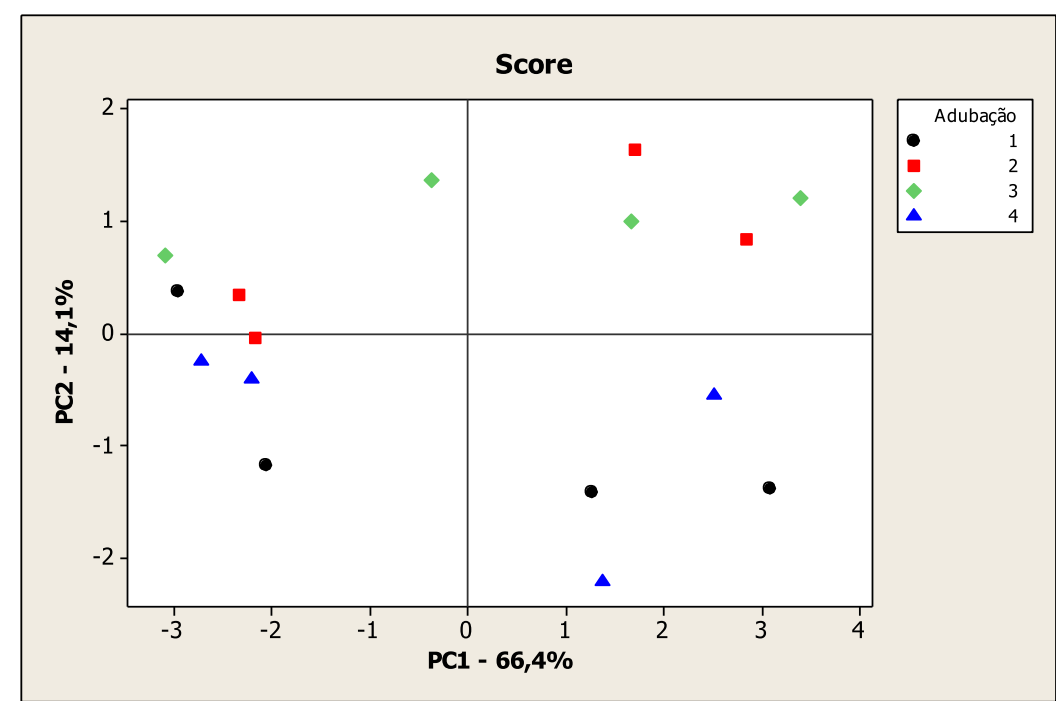

(c)

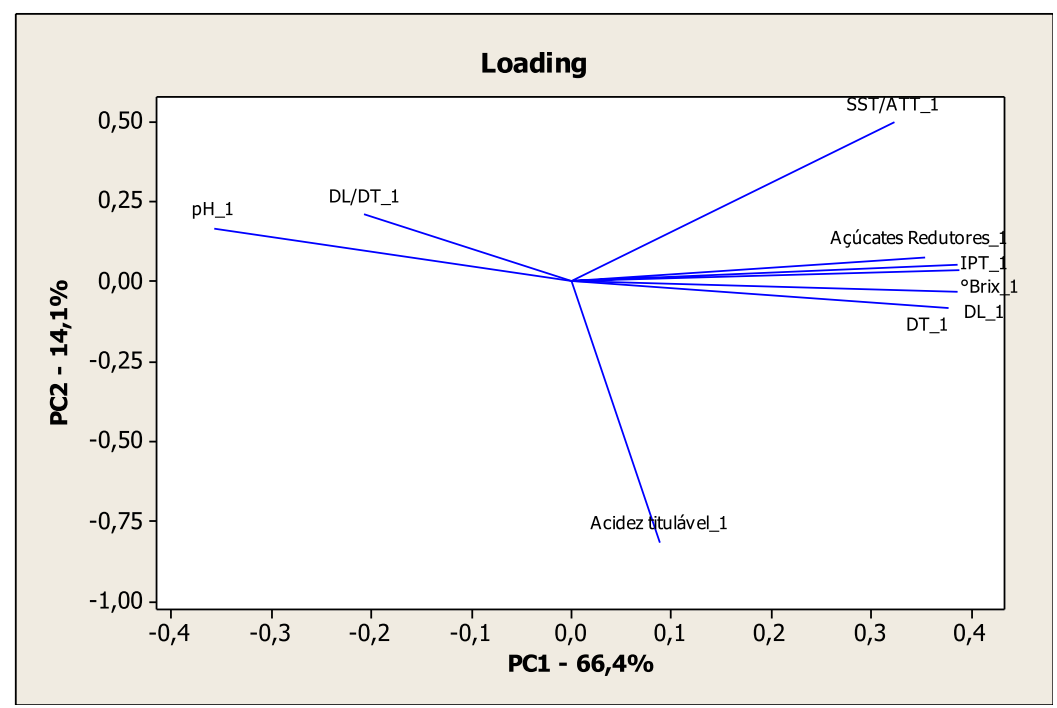

Ao contrário da PCA com todas as variáveis, limitando as variáveis para as análises físico-químicas clássicas foi possível observar a total separação entre as coletas 3 e 4 , separadas das coletas 1 e 2 pela PC1. Analisando o gráfico de scores em conjunto com o de loadings foi possível observar que o aumento do $\mathrm{pH}$ e da relação DL/DT influencia mais nas primeiras coletas, portanto goiabas mais verdes, enquanto que o aumento das demais estão relacionados as duas últimas coletas, dando destaque para a relação SST/ATT que se destaca nas amostras $\mathrm{N}_{2}$ e $\mathrm{N}_{1}$ das coletas $\mathrm{C}_{3}$ e $\mathrm{C}_{4}$, e acidez titulável nas amostras $\mathrm{N}_{0}$ e $\mathrm{N}_{3}$ das mesmas coletas. Contudo, foi possível observar que as variáveis foram capazes de distinguir entre os estádios de desenvolvimento da fruta. 
Considerando-se a adubação e restringindo-se as variáveis para as análises clássicas citadas acima foi possível obter uma separação entre dois grupos com relação à componente principal 2 (PC2), um referente a $\mathrm{N}_{0}$ e $\mathrm{N}_{3}$ e outro a $\mathrm{N}_{1}$ e $\mathrm{N}_{2}$, com exceção da amostra $\mathrm{N}_{0}-\mathrm{C} 1$ que ficou mais próxima das amostras de adubação $\mathrm{N}_{1}$ e $\mathrm{N}_{2}$.

De forma geral as amostras adubadas com $\mathrm{N}_{2}$ apresentaram características superiores as adubadas com a dose máxima $\mathrm{N}_{3}$, para a maioria das variáveis relacionadas a qualidade da fruta. Com base nesses resultados, pode-se dizer que não há vantagem no aumento da adubação nitrogenada para doses muito elevadas. 


\section{CONCLUSÃO}

A conclusão foi dividida em duas partes, a primeira avaliando as análises de diâmetros e análises clássicas com o desenvolvimento e a adubação, e a segunda as análises por técnicas de separação.

Com o desenvolvimento foi observado um aumento dos diâmetros, tanto longitudinal (DL) quanto transversal (DT), e diminuição da relação entre eles (DL/DT). Também foi observado aumento da acidez total titulável (ATT), menos pronunciado para N1 e N2, no entanto diminuição do pH. O índice de polifenóis totais (IPT), sólidos solúveis totais (SST) e a relação SST/ATT também aumentaram com exceção das amostras adubadas com $\mathrm{N}_{1}$, já os açúcares redutores totais aumentaram com o desenvolvimento para todas as adubações.

Na goiaba madura, a ausência de adubação, $\mathrm{N}_{0}$, proporcionou maiores valores de DT, ATT, SST. Dentre as amostras adubadas, $\mathrm{N}_{1}$ se destacou apresentando maiores valores de açúcares redutores, $\mathrm{N}_{2}$ maior relação SST/ATT e IPT, e $\mathrm{N}_{3}$ maior relação DL/DT, $\mathrm{pH}$ e valor de DL.

Não foi observada uma melhora ou piora de todas as características avaliadas com o aumento da adubação na goiaba madura, no entanto $\mathrm{N}_{2}$ se destaca, pois proporcionou melhoras para variáveis importantes tanto para indústria processadora, quanto para o consumo in natura, SST e a relação SST/ATT. Além disso, foi possível observar pela análise de componentes principais (PCA), que as amostras adubadas com dose máxima apresentaram comportamento semelhante as amostras sem adubação, contudo, com base nas amostras analisadas, a adubação com dose máxima é desnecessária, proporcionando apenas aumento do custo da produção.

Para as análises por técnicas de separação, em geral com o desenvolvimento foi observado aumento dos açúcares redutores e sacarose, sendo que o aumento da sacarose foi menos pronunciado, apresentando valores menores que os açúcares redutores na goiaba madura. Nos primeiros estádios de desenvolvimento a arabnose se destacou nas amostras de pectina hidrolisada, sendo que na goiaba madura se destacaram novamente a arabnose, mas também, glicose e ramnose. O ácido ascórbico, desidroascórbico, betacaroteno e licopeno também aumentaram com o desenvolvimento, sendo que para a vitamina $\mathrm{C}$ o aumento foi observado em ambas às etapas de coletas. Vale destacar que a etapa de coletas de 2010 apresentou menores teores de ácido ascórbico e de betacaroteno na goiaba madura que a etapa de 2012. 
Em relação a adubação, na goiaba madura a adubação máxima apresentou efeito negativo no teor de açúcares redutores e aumento da sacarose. Já a adubação $\mathrm{N}_{2}$ apresentou comportamento distinto em relação às duas diferentes etapas de coletas. $\mathrm{Na}$ etapa de $2010, \mathrm{~N}_{2}$ proporcionou maiores teores tanto de ácido ascórbico quanto de betacaroteno, no entanto na etapa de 2012, os maiores teores não foram observados nessa adubação. Contudo, não podemos afirmar que a adubação proporciona melhoras ou não apenas com o estudo de duas etapas de coletas em épocas diferentes. Uma vez que a estação do ano em que a goiaba é cultivada pode influenciar essas variáveis, como teor de vitamina $\mathrm{C}$ e carotenóides, para confirmar que $\mathrm{N}_{2}$, por exemplo, tem efeito positivo ou negativo é necessária à realização de novas coletas nessas épocas distintas e assim confirmar se o comportamento é semelhante ao observado em 2010 e 2012. 


\section{REFERÊNCIAS BIBLIOGRÁFICAS}

ADALID, A. M.; MARTÍNEZ, J. M. H.; ROSELlÓ, S.; MAQUIEIRA, A.; NUEZ, F.Fast determination of prominent carotenoids in tomato fruits by CEC using methacrylate Esterbased monolithic columns. Electrophoresis, v. 28, p. 4120-4127, 2007.

ALMAGRO, I.; SAN ANDRES, M. P.; VERA, S. Determination of water-soluble vitamins in pharmaceitical preparations by reversed-phase liquid chromatography with a mobile phase containing sodium dodecylsulphate and n-propanol. Chromatographia, v. 55, p. 185-188, 2002 .

ALMEIDA, M. C.; BAUMGARTNER, J. G. Efeitos da adubação nitrogenada e potássica na produção e na qualidade de frutos de laranjeira-'Valência'. Revista Brasileira de Fruticultura, Jaboticabal, v. 24, n. 1, p. 282-284, 2002.

AL-RUQAIE, I. M.; KASAPIS, S.; ABEYSEKERA, R. Structural properties of pectin-gelatin gels. Part II: effect of sucrose/glucose syrup. Carbohydrate Polymers, v. 34, p. 309 - 321, 1997.

ANDREWS, P.K.; LI, S. Parcial purification and characterization of b-D-galactosidase from sweet cherry, a nonclimateric fruit. Journal Agricultural and Food Chemistry, v. 42, n. 10, p. 2177-2182, 1994.

AQUINO, F. W. B.; AMORIM, A. G. N.; PRATA, L. F.; NASCIMENTO, R. F. Determinação de aditivos, aldeídos furânicos, açúcares e cafeína em bebidas por cromatografia líquida de alta eficiência: validação de metodologias. Ciência e Tecnologia de Alimentos, Campinas, v. 24, n. 1, p 32 - 38, 2004.

AQUINO-NETO, F. R; NUNES, D. S. S. Cromatografia: princípios básicos e técnicas afins. Rio de Janeiro: Interciência, 2003. 187p.

ARNOUS, A.; MEYER, A. S. Quantitative prediction of cell wall polysaccharide composition in grape (Vitis vinifera L.) and apple (Malus fomestica) skins from acid hydrolysis monosaccharide profiles. Journal of Agricultural and Food Chemistry, v. 57, p. 3611-3619, 2009.

AROUCHA, E. M.; VIANNI, R. Água de coco por cromatografia líquida e pelo método titulométrico. Revista Ceres, v. 49, p. 245-251, 2002. 
ASSIS, S. A.; LIMA, D. C.; OLIVEIRA, O. M. M. F. Activity of pectinmethylesterase, pectin content and vitamin $\mathrm{C}$ in acerola fruit at various stages of fruit development. Food Chemistry, v. 74, p. 133-137, 2001.

ASSUNÇÃO, R. B.; MERCADANTE, A. Z. Carotenoids and ascorbic acid from cashew apple (Anacardium occidentale L.): variety and geographic affects. Food Chemistry, v. 81, p. 495-502, 2003.

AZEVEDO, C. H.; RODRIGUEZ-AMAYA, D. B. Carotenoid composition of kale as influenced by maturity, season and minimal processing. Journal of the Science of Food and Agriculture, v. 85, p. 591-597, 2005.

AZZOLINI, M. Fisiologia pós-colheita de goiabas 'Pedro Sato': estádios de maturação e padrão respiratório. 2002. 100f. Dissertação (Mestrado)- Escola Superior de Agricultura "Luiz de Queiroz", Universidade de São Paulo, Piracicaba, 2002.

AZZOLINI, M.; JACOMINO, A. P.; BRON, I. U. Índices para avaliar qualidade pós-colheita de goiabas em diferentes estádios de maturação. Pesquisa Agropecuária Brasileira, v. 39, n. 2, p. 139-145, 2004.

AZZOLINI, M.; JACOMINO, A. P.; SPOTO, M; H. F. Estádios de maturação e qualidade pós-colheita de goiabas 'Pedro Sato'. Revista Brasileira de Fruticultura, v. 26, n. 1, p. 2931, 2004.

BARATA-SOARES, A. D.; GOMEZ, M. L. P. A.; MESQUITA, C. H.; LAJOLO, F. M. Ascorbic acid biosynthesis: a precursor study on plants. Brazilian Journal of Plant Physiology, v. 16, n. 3, p. 147-154, 2004.

BARCIA, M. T.; JACQUES, A. C.; PERTUZATTI, P. B.; ZAMBIAZI, R. C. Determinação de ácido ascórbico e tocoferóis em frutas por CLAE. Semina: Ciências Agrárias, v. 31, n. 2, p. 381-390, 2010.

BARROS, A. I. R. N. A.; SILVA, A. P.; GONÇALVES, B.; NUNES, F. M. A fast, simple, and reliable hydrophilic interaction liquid chromatography method for the determination of ascorbic and isoascorbic acids. Analytical and Bioanalytical Chemistry, v. 396, p. 1863$1875,2010$.

BAUERNFEIND, J. C. Carotenoid vitamin A precursors and analogs in foods and feeds. Journal of Agricultural and Food Chemistry, v. 20, n. 3, p. 456-473, 1972.

BELIN, G. K.; GULAÇAR, F. O. Separation of chlorins and carotenoids in capillary electrophoresis. Journal of Chromatographic Science, v. 45, p. 593-599, 2007. 
BEM-AMOTZ, A. FISHLER, R. Analysis of carotenoids with emphasis on 9-cis $\beta$-carotene in vegetables and fruits commonly consumed in Israel. Food Chemistry, v. 62, n. 4, p. 515$520,1998$.

BERNARDES-SILVA, A. P. F.; LAJOLO, F. M.; CORDENUNSI, B. R. Evolução dos teores de amido e açúcares solúveis durante o desenvolvimento e amadurecimento de diferentes cultivares de manga. Ciência e Tecnologia de Alimentos, Campinas, v. 23, p. 116-120, 2003.

BRANDÃO, E. M.; ANDRADE, C. T. Influência de fatores estruturais no processo de geleificação de pectinas de alto grau de metoxilação. Polímeros: Ciência e Tecnologia, p. 38-44, 1999.

BRASIL. Agência Nacional de Vigilância Sanitária. Resolução no 899 de 29 de maio de 2003. Guia Para Validação De Métodos Analíticos e Bioanalíticos. Diário Oficial da União, Brasília, 31 de março de 2003. Disponível em: <http://www.anvisa.gov.br/legis/resol/2003/re/899_03re.htm> Acesso em: 15 dez. 2011.

BRASIL. Agência Nacional de Vigilância Sanitária. no 33 de 13 de janeiro de 1998. Tabela I: ingestão diária recomendada de vitaminas, minerais e proteínas. Diário Oficial da União, Brasília, 13 de janeiro de 1998. Disponível em: $<$ http://www.anvisa.gov.br/legis/portarias/33_98.htm> Acesso em: 15 dez. 2011.

BRASIL. Ministério da Agricultura. Portaria $n^{\circ} 76$ de 26 de novembro de 1986. Diário Oficial da República Federativa do Brasil, Brasília, 28 nov. 1986. Seção 1, pt. 2.

BRAZ FILHO, R. Contribuição da fitoquímica para o desenvolvimento de um país emergente. Química Nova, n. 33, p. 229-239, 2010.

BRUNINI, M. A.; OLIVEIRA, A. L.; VARANDA, D. B. Avaliação da qualidade de polpa de goiaba "Paluma" armazenada a $-20^{\circ} \mathrm{C}$. Revista Brasileira de Fruticultura, v. 25, n. 3, p. 394-396, 2003.

CAMPOS, F. M.; RIBEIRO, S. M. R.; LUCIA, C. M. D.; PINHEIRO-SANT'ANA, H. M. Optimization of methodology to analyze ascorbic and dehydroascorbic acid in vegetables. Química Nova, v. 32, n. 1, p. 87-91, 2009.

CARDOSO, S. L. Fotofísica de carotenóides e o papel antioxidante de $\beta$-caroteno. Química Nova, v. 20, n. 5, p. 535-540, 1997. 
CARRIEDO, M. O. N.; BUSLIG, B. S.; SHAW, P. E. Simultaneous detection of dehydroascorbic, ascorbic and some organic acids in fruits and vegetables by HPLC. Journal of Agricultural and Food Chemistry, v. 40, p. 1127-1130, 1992.

CARVAlHO, A. Z.; SILVA, J. A. F.; LAGO, C. L. Determination of mono- and disaccharides by capillary electrophoresis with contactless conductivity detection. Electrophoresis, v. 24, p. 2138-2143, 2003.

CARVAlHO, H. A. DE; CHITARRA, M. I. F.; CHITARRA, A. B.; CARVALHO, H. DE. Efeito da atmosfera modificada sobre componentes da parede celular da goiaba. Ciência e Agrotecnologia, v. 25, n. 3, p. 605-615, 2001.

CARVALHO, V. D. Qualidade e conservação pós-colheita de goiabas. Informe Agropecuário, v. 17, n. 179, p. 48-54, 1994.

CASTRO-PUYANA，M.; GARCÍA-CAÑAS，V.; SIMÓ，C.; CIFUENTES，A. Recent advances in the application of capillary electromigration methods for food analysis and foodomics. Electrophoresis, v. 33, p. 147-167, 2012.

CHAN JR, H. T.; BREKKE, J. E.; CHANG, T. Nonvolatile organic acids in guava. Journal of Food Science, v. 36, p. 237-239, 1971.

CHAROENSIRI, R.; KONGKACHUICHAI, R.; SUKNICOM, S.; SUNGPUAG, P. Betacarotene, lycopene, and alpha-tocopherol contents of selected Thai fruits. Food Chemistry, v. 113, p. 202-207, 2009.

CHIARI, M.; NESI, M.; CARREA, G.; RIGHETTI, P. G. Determination of total vitamin C in fruits by capillary zone electrophoresis. Journal of Chromatography, v. 645, p. 197-200, 1993.

CHOUDHURY, M. M.; ARAÚJO, J. L. P.; NETO, L. G.; RESENDE, J. M.; DA COSTA, T. S.; SCAGGIANTE, G. Goiaba: pós-colheita. Brasília: EMBRAPA, 2001. 45p. (Série Frutas do Brasil).

CHRONAKIS, I. S.; KASAPIS, S.; ABEYSEKERA, R. Structural properties of gelatinpectin gels. Part I: effect of ethylene glycol. Food Hydrocolloids, v. 11, n. 3, p. 271-279, 1997.

COETZEE, B.; SCHOLS, H. A.; WOLFAARDT, F. Determination of pectin content of eucalyptus wood. Holzforschung, v. 65, p. 327-331, 2011. 
COLLINS, C.H; BRAGA, G.L.; BONATO, P.L. Introdução a métodos cromatográficos. $7^{\text {a }}$ ed. Campinas: Editora da Unicamp, 1997. 279 p.

DEGANI, A. L.; CASS, Q.B.; VIEIRA, P. C. Cromatografia - Um breve ensaio. Química Nova, v. 1, n. 7, p. 21-25, 1998.

DHINGRA, M. K.; GUPTA, O. P.; CHUNDAWAT, B. S. Studies on pectin yield and quality of some guava cultivars in relation to cropping season and fruit maturity. Journal of Food Science and technology, v. 20, n. 1, p. $10-13,1983$.

DUAN, X.; CHENG, G.; YANG, E.; YI, C.; RUENROENGKLIN, N.; LU, W.; LUO, Y.; JIANG, Y. Modification of pectin polysaccharides during ripening of postharvest banana fruit. Food Chemistry, v. 11, p. 144-149, 2008.

DURIGAN, J. F.; MATTIUZ, BEM-HUR; MORGADO, C. M. A. Cultura da goiaba do plantio à comercialização. Jaboticabal: Santa Terezinha, 2009. v. 2, p.129-170.

EL BULK, R. E. BABIKER, E. F. E.; EL TINAY, A. H. Changes in chemical composition of guava fruits during development and ripening. Food Chemistry, v. 59, n. 3, p. 395-399, 1997.

EL KHADEM, H. S. Carbohydrate chemistry: monosaccharides and their oligomers. London: Academic Press, 1988. 228 p.

ENGLYST, H.; WIGGINS, H. S.; CUMMINGS, J. H. Determination of the non-starch polysaccharides in plant foods by gas-liquid chromatography of constituent sugars as alditol acetates. Analyst, v. 107, p. 307-318, 1982.

ESTEVES, M. T. C.; CARVALHO, V. D. Modificações nos teores de amido, açúcares e grau de doçura de frutos de seis cultivares de goiabeira (Psidium guajava L.) em diferentes estádios de maturação. Ciência e Prática, v. 6, n. 2, p. 208-218, 1982.

FELTL, L.; PACÁKOVÁ, V.; STULIK, K.; VOLKA, K. Reliability of carotenóide analyses: a review. Current Analytical Chemistry, v. 1, p. 93-102, 2005.

FERNANDES, A. G.; MAIA, G. A.; SOUSA, P. H. M.; COSTA, J. M. C.; FIGUEIREDO, R. W.; PRADO, G. M. Comparação dos teores em vitamina c, carotenóides totais, antocianinas totais e fenólicos totais do suco tropical de goiaba nas diferentes etapas de produção e influência da armazenagem. Alimentos e Nutrição, v. 18, n. 4, p. 431-438, 2007. 
FERTONANI, H. C. R. Estabelecimento de um modelo de extração ácida de pectina de bagaço de maçã. 2006. 82 f. Dissertação (Mestrado) - Universidade Estadual de Ponta Grossa, Ponta Grossa, 2006.

FIEHN, O. Metabolomics - the link between genotypes and phenotypes. Plant Molecular Biology, v. 48, p. 155-171, 2002.

FISHMAN, M. L.; PFEFFER, P. E.; BARFORD, R. A.; DONER, L. W. Studies of pectin solution properties by high-performance size exclusion chromatrography. Journal of Agricultural and Food Chemistry, v. 32, p. 372-378, 1984.

FISSORE, E. N.; PONCE, N. M. A.; PLA, M. DE E.; STORTZ, C. A.; ROJAS, A. M.; GERSCHENSON, L. N. Characterization of acid-extracted pectin-enriched products obtained from red beet (Beta vulgaris L. var. conditiva) and butternut (Cucurbita moschata duch ex poiret). Journal of Agricultural and Food Chemistry, v. 58, p. 3793-3800, 2010.

FRAZIER, R. A.; PAPADOPOULOU, A. Recent advances in the application of capillary electrophoresis for food analysis. Electrophoresis, v. 24, p. 4095-4105, 2003.

FUKUSHI, K.; TAKEDA, S.; WAKIDA, S.; YAMANE, M.; HIGASHI, K.; HIIRO, K. Determination of ascorbic acid in vegetables by capillary zone electrophoresis. Journal of Chromatography A, v. 772, p. 313-320, 1997.

GALIANA-BALAGUER, L.; ROSELLÓ, S.; HERRERO-MARTÍNEZ, J. M.; MAQUIEIRA, A.; NUEZ, F. Determination of 1-ascorbic acid in Lycopersicon fruits by capillary zone electrophoresis. Analytical biochemistry, v. 296, p. 218- 224, 2001.

GARDNER, P. T.; WHITE, T. A. C.; McPHAIL, D. B.; DUTHIE, G. G. The relativecontributions of vitamin $\mathrm{C}$, carotenoids and phenolic acids to the antioxidant potential of fruit juices. Food Chemistry, v. 68, p. 471-474, 2000.

GEIGERT, J.; HIRANO, D. S.; NEIDLEMAN, S. L. High-performance liquid chromatographic method for the determination of L-ascorbic and D-isoascorbic acid. Journal of Chromatograhy, v. 206, p. 396-399, 1981.

GERHARDT, L. B. A.; MANICA, I.; KIST, H.; SIELES, R. L. Caracteristicas físicoquímicas dos frutos de quatro cultivares e três clones de goiabeira em Porto Lucena, RS. Pesquisa Agropecuária Brasileira, v. 32, n.2, p. 185-192, 1997. 
GLYAD, V. M. Determination of monosaccharides, disaccharides, and oligosaccharides in the same plant sample by high-performance liquid chromatography. Russian Journal of Plant Physiology, v. 49, n. 2, p. 277-282, 2002.

GOMEZ, M. L. P. A.; LAJOLO, F. M. Ascorbic acid metabolism in fruits: activity of enzymes involved in synthesis and degradation during ripening in mango and guava. Journal of the Science of Food and Agriculture, v. 88, p. 756-762, 2008.

GONÇALVES, C. A. A.; LIMA, L. C. DE O.; LOPES, P. S. N.; PRADO, M. E. T. Caracterização física, físico-química, enzimática e de parede celular em diferentes estádios de desenvolvimento da fruta de figueira. Ciência e Tecnologia de Alimentos, Campinas, v. 26, p. 220-229, 2006.

GONZÁLEZ, I. A.; OSORIO, C.; MARTÍNEZ, A. J. M.; MIRET, M. L. G.; HEREDIA, F. J. Application of tristimulus colorimetry to evaluate colou changes during the ripening of Colombian guava (Psidium guajava L.) varieties with different carotenóide pattern. International Journal of Food Science and Technology, v. 46, p. 840-848, 2011.

GOUVEIA, E. R.; NASCIMENTO, R. T.; SOUTO-MAIOR, A. M. Validação de metodologia para caracterização química de cana-de-açúcar. Química Nova, v. 32, n. 6, p. 1500-1503, 2009.

GOUVEIA, J. P. G.; ALMEIDA, F. A. C.; MEDEIROS, B. G. S.; RIBEIRO, C. F. A.; DUARTE, S. M. A. Determinação de características físico-químicas da goiaba: goiabeiras no semi-árido da Paraíba. Revista Brasileira de Produtos Agroindustriais, v. 6, n. 1, p. 35-38, 2004.

GOUVEIA, J. P. G.; ALMEIDA, F. A. C.; MEDEIROS, B. G. S.; RIBEIRO, C. F. A.; SILVA, M. M. Maturação da goiaba (Psidium guajava L.) mediante parâmetros físicoquímicos. Revista Brasileira de Produtos Agroindustriais, v. especial, n. 1, p. 85-94, 2003.

GUÇLU, K.; SOZGEN, K.; TUTEM, E.; OZYUREK, M.; APAK, R. Spectrophotometric determination of ascorbic acid using copper (II)-neocuproine reagent in beverages and pharmaceuticals. Talanta, v. 65, p. 1226-1232, 2005.

HERNÁNDEZ, Y.; LOBO M. G.; GONZÁLEZ, M. Determination of vitamin C in tropical fruits: a comparative evaluation of methods. Food Chemistry, v. 96, p. 654-664, 2006.

HERRERO, M.; GARCÍA-CAÑAS, V.; SIMO, C.; CIFUENTES, A. Recent advances in the application of capillary electromigration methods for food analysis and foodomics. Electrophoresis, v. 31, p. 205-228, 2010. 
HULSHOF, P. J. M.; XU, C.; BOVENKAMP, P.; MUHILAL; WEST, C. E. Application of a validated method for the determination of provitamin A carotenoids in Indonesian foods of different maturity and origin. Journal of Agricultural and Food Chemistry, v. 45, p. 1174$1179,1997$.

HWANG, J.; KOKINI, J. L. Contribution of the side branches to rheological properties of pectins. Carbohydrate Polymers, v. 19, p. 41-50, 1992.

HWANG, J.; PYUN, Y. R.; KOKINI, J. L. Sidechains of pectins: some thoughts on their role in plant cell walls and foods. Food Hydrocolloids, v. 7, n. 1, p. 39-53, 1993.

INSTITUTO BRASILEIRO DE GEOGRAFIA E ESTATÍSTICA, (IBGE). Lavoura permanente. Disponível em: < http://www.ibge.gov.br/estadosat/index.php >. Acesso em: 15 out. 2011.

IGLESIAS, M .T.; LOZANO, J.E.; Extraction and characterization of sunflower pectin. Journal of Food Engineering, n. 62, p. 215-223, 2004.

IJERI, V. S.; JAISWAL, P. V.; SRIVASTAVA, A. K. Chemically modified electrodes based on macrocyclic compounds for determination of Vitamin $\mathrm{C}$ by electrocatalytic oxidation. Analytica Chimica Acta, v. 439, p. 291-297, 2001.

INSTITUTO ADOLFO LUTZ. Métodos físico-químicos para análise de alimentos (versão eletrônica). São Paulo: Instituto Adolfo Lutz, 2008. 1020 p.

INSTITUTO ADOLFO LUTZ. Normas analíticas do Instituto Adolfo Lutz: métodos químicos e físicos para análise de alimentos. 4. ed. São Paulo. Instituto Adolfo Lutz, 2008. v. 15 , p. 583-585.

JAGER, A. V.; TAVARES, M. F. M. Determinação simultânea de cátions por eletroforese capilar: fundamentos e aplicações. Química Nova, v. 24, n. 3, p. 363-373, 2001.

JAGER, A. V.; TONIN, F. G.; TAVARES, M. F. M. Comparative evaluation of extraction procedures and method validation of determination of carbohydrates in cereals and dairy products

by capillary electrophoresis. Journal of Separation Science, v. 30, p. 586-594, 2007.

JAIN, N.; DHAWAN, K.; MALHOTRA, S. P.; SIDDIQUI, S.; SINGH, R. Compositional and enzymatic changes in guava (Psidium guajava L.) fruits during ripening. Acta Physiologiae Plantarum, v. 23, n. 3, p. 357-362, 2001. 
JAIN, N.; DHAWAN, K.; MALHOTRA, S. P.; SINGH, R. Biochemistry of fruit ripening of guava (Psidium guajava L.). Plant Foods for Human Nutrition, v. 58, p. 309-315, 2003.

JOYE D. D., LUZIO G. A., Process for selective extraction of pectins from plant material by differential pH. Carbohydrate Polymers, v. 43, p. 337-342, 2000.

FRANCISCO JUNIOR, W. E. Carboidratos: estrutura, propriedades e funções. Química Nova na Escola, n. 29, p. 8-13, 2008.

KABASAKALIS, V.; SIOPIDOU, D.; MOSHATOU, E. Ascorbic acid content of commercial fruit juices and its rate of loss upon storage. Food Chemistry, v. 70, p. 325-328, 2000.

KADER, A. A. B. Contributions of fruits and vegetables. Horticulture and humam health, Englewood Cliffs: Pretice-Hall, 1988. p. 18-32.

KASHYAP, D. R.; VOHRA, P. K.; CHOPRA, S.; TEWARI, R. Applications of pectinases in the commercial sector: a review. Bioresource Technology, v. 77, n. 3, p. 215-227, 2001.

KE, D.; EL-WAZIR, F.; COLE, B.; MATEOS, M.; KADER, A. A. Tolerance of peach and nectarine fruits to insecticidal controlled atmospheres as influenced by cultivar, maturity, and size. Postharvest Biology and Technology, v. 4, p. 135-146, 1994.

KIMURA, M.; KOBORI, C. N.; RODRIGUEZ-AMAYA, D. B.; NESTEL, P. Screening and HPLC methods for carotenoids in sweetpotato, cassava and maize for plant breeding trials. Food Chemistry, v. 100, p. 1734-1746, 2007.

KLIEMANN, E. Extração e Caracterização da Pectina da Casca do Maracujá- amarelo (Passiflora edulis flavicarpa). 2006. 75 f. Dissertação (Mestrado em Ciência dos Alimentos). Universidade Federal de Santa Catarina, Florianópolis - SC, 2006.

KOH, E. V.; BISSELL, M. G.; ITO, R. K. Measurement of vitamin C by capillary electrophoresis in biological fluids and fruit beverages using a stereoisomer as an internal standard. Journal of Crhomatography, v. 633, p. 245-250, 1993.

KRAVTCHENKO, T. P.; VORAGEN, A. G. J.; PILNIK, W. Analytical comparison of three industrial pectin preparations. Carbohydrate Polymers, v. 18, p. 17-25, 1992. 
KUHN, S. H.; PAULUS, A.; GASSMANN, E; WIDMER, M. Influence of borate complexation on the eletrophoretic behavior of carbohydrates in capillary electrophoresis. Analytical Chemistry, v. 63, p. 1541-1547, 1991.

KUMAR, A. CHAUHAN, G. S. Extraction and characterization of pectin from apple pomace and its evaluation as lipase (steapsin) inhibitor. Carbohydrate Polymers, v. 82, p. 454-459, 2010 .

KUSKOSKI, E. M.; ASUERO, A. G.; MORALES, M. T.; FETT, R. Frutos tropicais silvestres e polpas de frutas congeladas: atividade antioxidante, polifenóis e antocianinas. Ciência Rural, v. 36, n. 4, p. 1283-1287, 2006.

LANDERS, J. P. Handbook of capillary electrophoresis. Boca Raton: CRC, 1997. p. 348372.

LEE, H. L.; CHEN, S. C. Microchip capillary electrophoresis with amperometric detection for several carbohydrates. Talanta, v. 64, p. 210-216, 2004.

LEE, S.K.; KADER, A.A. Preharvest and postharvest factors influencing vitamin C content of horticultural crops. Postharvest Biology and Technology, v. 20, p. 207-220, 2000.

LEITE, K. M. DA S. C.; DE ASSIS, S. A.; TADIOTTI, A. C.; OLIVEIRA, O. M. M. F. Evaluation of guava during different phases of the industrial processing. International Journal of Food Sciences and Nutrition, v. 60, p. 81-88, 2009.

LEITE, K. M. DA S. C.; TADIOTTI, A. C.; BALDOCHI, D.; OLIVEIRA, O. M. M. F. Partial purification, heat stability and kinetic characterization of the pectinmethylesterase from Brazilian guava, Paluma cultivars. Food Chemistry, v. 94, p. 565-572, 2006.

LEVIGNE, S.; RALET, M.C.; THIBAULT, J.F. Characterization of pectins extracted from fresh sugar beet under different conditions using a experimental design. Carbohydrate Polymers, v. 19, p. 145-153, 2002.

LI, J.; SUN, J.; WANG, Z.; HUANG, L. Simultaneous determination of aldoses and uronic acids of citrus pectin by LC with precolumn derivatization and UV detection. Chromatographia, v. 72, p. 849-855, 2010.

LIAO T.; JIANG, C.; WU, M.; HWANG, J.; CHANG, H. Quantification of L-ascorbic acid and total ascorbic acid in fruits and spinach by capillary zone electrophoresis. Electrophoresis, v. 22, p. 1484-1488, 2001. 
LIMA, M. A. C. L.; ASSIS, J. S.; GONZAGA NETO, L. Caracterização dos frutos de goiabeira e seleção de cultivares do submédio São Francisco. Revista Brasileira de Fruticultura, Jaboticabal, v. 24, n. 1, p. 273-276, 2002.

LIMA, M. A. C.; BASSOI, L. H.; SILVA, D. J.; SANTOS, P. S.; PAES, P. C. P.; RIBEIRO, P. R. A.; DANTAS, B. F. Effects of levels of nitrogen and potassium on yield and fruit maturation of irrigated guava trees in the São Francisco Valley. Revista Brasileira de Fruticultura, v. 30, n. 1, p. 246-250, 2008.

LING, B. L.; BAEYENS, W. R. G.; ACKER, P. V.; DEWAELE, C. Determination of ascorbic acid and isoascorbic acid by capillary zone electrophoresis: application to fruit juices and to a pharmaceutical formulations. Journal of Pharmaceutical \& Biomedical Analysis, v. 10, p. 717-721, 1992.

LISIEWSKA, Z.; KMIECIK, W. Effects of level of nitrogen fertilizer, processing conditions and period of storage of frozen broccoli and cauliflower on vitamin $\mathrm{C}$ retention. Food Chemistry, v. 57, n. 2, p. 267-270, 1996.

LU, Q.; ZHANG, Y.; WANG, Y.; WANG, D.; LEE, R.; GAO, K.; BYRNS, R.; HEVER, D. California hass avocado: profiling of carotenoids, tocopherol, fatty acid, and fat content during maturation and from different growing areas. Journal of Agricultural and Food Chemistry, v. 57, p. 10408-10413, 2009.

LU, X.; SEIB, P. A. Assay of dehydroascorbic acid in bread and dough added as acrystalline dimer. Cereal Chemistry, v. 75, n. 2, p. 200-206, 1998.

LYKKESFELDT, J. Determination of ascorbic acid and dehydroascorbic acid in biological samples by high-performance liquid chromatography using subtraction methods: reliable reduction with tris[2-carboxyethyl]phosphine hydrochloride. Analytical Biochemistry, v. 282, p. 89-93, 2000.

MAIA, J. L. T.; BASSOI, L. H.; SILVA, D. J.; LIMA, M. A. C.; ASSIS, J. S.; MORAIS, P. L. D. Assessment on nutrient levels in the aerial biomass of irrigated guava in São Francisco valley, Brazil. Revista Brasileira de Fruticultura, v. 29, n. 3, p. 705-709, 2007.

MANICA, I.; KIST, H.; MICHELETTO, E.L.; KRAUSE, C.A. Competição entre quatro cultivares e duas seleções de goiabeira. Pesquisa Agropecuária Brasileira, v. 33, n. 8, p. 1305-1313, 1998. 
MARINHO, C. S.; OLIVEIRA, M. A. B.; MONNERAT, P. H.; VIANNI, R.; MALDONADO, J. F. Fontes e doses de nitrogênio e a qualidade dos frutos do mamoeiro. Scientia Agricola, v. 58, n. 2, p. 345-348, 2001.

MARTIN, Z. J.; KATO, K. Processamento: produtos, características e utilização. In: INSTITUTO DE TECNOLOGIA DE ALIMENTOS. Goiaba: cultura, matéria-prima, processamento e aspectos econômicos. Campinas: ITAL, Instituto Campineiro de Ensino Agrícola, 1988. p.141-175.

MARTINEZ, V. R.; MELGAREJO, M. P.; HERnADEZ, G. F. Practicas integradas de viticultura. Madri: Mundi-Prensa, 2001. 278 p.

MASON, B. S.; SLOVER, H. T. A gas chromatographic method for the determination of sugar in foods. Journal of Agricultural and Food Chemistry, v. 19, n. 3, p. 551-554, 1971.

MATOS, G. D.; PEREIRA- FILHO, E. R.; POPPI, R. J.; ARRUDA, M. A. Z. Análise exploratória em química analítica com emprego de quimiometria: PCA e PCA de imagens.

Revista Analytica, n. 6, p. 38-50, 2003.

MEDEIROS, B. G. S.; GOUVEIA, J. P. G.; ALMEIDA, F. A. C.; RIBEIRO, C. F. A.; DUARTE, S. M. A. Características físicas da goiaba (Psidium Guajava 1.): efeito da adubação nitrogenada. Revista Brasileira de Produtos Agroindustriais, v. 6, n. 1, p. 47-53, 2004.

MERCADANTE, A. Z.; RODRIGUEZ-AMAYA, D. B. Effects of ripening, cultivar differences, and processing on the carotenoids composition of mango. Journal of Agricultural and Food Chemistry, v. 46, p. 128-130, 1998.

MERCADANTE, A. Z.; STECK, A.; PFANDER, H. Carotenoids from guava (Psidium guajava L.): isolation and structure elucidation. Journal of Agricultural and Food Chemistry, v. 47, p. 145-151, 1999.

MERCADO-SILVA, E.; BENITO-BAUTISTA, P.; GARCÍA-VELASCO, M. A. Fruit development, harvest índex and ripening changes of guava produced in central Mexico. Postharvest Biology and Technology, v. 13, p. 143-150, 1998.

MILLS, M. B.; DAMRON, C. M.; ROE, J. H. Ascorbic acid, dehydroascorbic acid, and diketogulonic acid in fresh and processed foods. Analytical Chemistry, v. 21, n. 6, p. $707-$ $709,1949$.

MORAES, F. P.; COLLA, L. M. Alimentos funcionais e nutracêuticos: definições, legislação e benefícios à saúde. Revista Eletrônica de Farmácia, v. 3, p. 109-122, 2006. 
MORAIS, F. L. "Carotenóides: Características Biológicas e Químicas". 2006. 70 f. Dissertação (monografia apresentada no curso de pós-graduação lato sensu em Qualidade em Alimentos para a obtenção do grau de Especialista). Centro de Excelência em Turismo, Universidade de Brasília, Brasília-DF, 2006.

MOREIRA, A. C. C. G. Caracterização de frutos de genótipos de cajá-umbuzeiras: teor de fitoquímicos bioativos e potencial antioxidante. 2011. $122 \mathrm{f}$. Dissertação (Mestrado em Ciência e Tecnologia de Alimentos) - Departamento de Ciências Domésticas, Universidade Federal Rural de Pernambuco, Recife, 2011.

MOREIRA, A. DA S.; SOUZA, A. DA S. VENDRUSCOLO, C. T. Determinação da composição de biopolímero por cromatografia em camada delgada: metodologia. Revista Brasileira de Agrociência, v. 4, n. 3, p. 222-224, 1998.

MORGADO, C. M. A.; DURIGAN, J. F.; LOPES, V. G.; SANTOS, L. O. Conservação póscolheita de goiabas 'Kumagai': efeito do estádio de maturação e da temperatura de armazenamento. Revista Brasileira de Fruticultura, v. 32, n. 4, p. 1001-1008, 2010.

MULLER, H. Determination of the carotenoid content in selected vegetables and fruit by HPLC and photodiode array detection. Zeitschrift Lebensm Unters Forsch A, v. 204, p. 8894, 1997.

MUNHOZ, C. L.; SANJINEZ-ARGANDOÑA, E. J.; SOARES-JÚNIOR, M. S. Extração de pectina de goiaba desidratada. Ciência e Tecnologia de Alimentos, v. 30, n. 1, p. 119-125, 2008 .

NAGY, S. Vitamin C contents of citrus fruit and their products: a review. Journal of Food Chemistry, v. 28, p. 8-18, 1980.

NATALE, W.; COUTINHO, E. L. M.; PEREIRA, F. M.; JUNIOR, M. M.; MARTINS, M. C. Efeito da adubação N, P e K no teor de sólidos solúveis totais de frutos de goiabeira (Psidium guajava L.). Alimentos e Nutrição, v. 6, p. 69-75, 1995.

NATALE, W.; PRADO, R. M.; ROZANE, D. E.; ROMUALDO, L. M. Efeitos da calagem na fertilidade do solo e na nutrição e produtividade da goiabeira. Revista Brasileira Ciência do Solo, v. 31, p. 1475-1485, 2007.

NELSON, D. L. e COX, M. M. Lehninger-Princípios de Bioquímica. $4^{\mathrm{a}}$ Ed.São Paulo: Sarvier, 2006. 1232p. 
NOGUEIRA, J.M.F. Mikhail S. Tswett: Um legado para a cromatografia moderna. Química, n. 100, p. 51-56, 2006.

NOJAVAN, S.; KHALILIAN, F.; KIAIE, F. M.; RAHIMI, A.; ARABANIAN, A.; CHALAVI, S. Extraction and quantitative determination of ascorbic acid during different maturity stages of Rosa Canina L. fruit. Journal of Food Composition and Analysis, v. 21, p. 300-305, 2008.

OEFNER, P.J.; VORNDRAN, A. E.; GRILL, E.; HUBER, C.; BONN, G. K. Capillary zone electrophoretic analysis of carbohydrates by direct and indirect UV detection. Chromatographia. v. 34, n. 5-8, p. 308-316, 1992.

OKIEI, W.; OGUNLESI, M.; AZEEZ, L.; OBAKACHI, V.; OSUNSANMI, M.; NKENCHOR, G. The voltammetric and titrimetric determination of ascorbic acid levels in tropical fruit samples. International Journal of Electrochemical Science, v. 4, p. 276-287, 2009.

OLIVEIRA, M. N. S.; GUSMÃO, E.; LOPES, P. S. N.; SIMÕES, M. O. M.; RIBEIRO, L. M.; DIAS, B. A. S. Estádio de maturação dos frutos e fatores relacionados aos aspectos nutritivos e de textura da polpa de pequi. Revista Brasileira de Fruticultura, v. 28, n. 3, p. 380-386, 2006.

PADULA, M.; RODRIGUEZ-AMAYA, D. B. Characterization of the carotenoids and assessment of the vitamin A value of Brazilian guavas (Psidium guajava L.). Food Chemistry, v. 20, p. 11-19, 1986.

PAGÁN, J.; IBARZ, A.; LLORCA, M.; PAGÁN, A.; BARBOSA-CÁNOVAS, G.V. Extraction and characterization of pectin from stored peach pomace. Food Research International, v. 34, p. 605-612, 2001.

PARVIAINEN, M.T., NYYSSONEN, K., 1992. Ascorbic acid. In: LEENHEER, A. P. D.; LAMBERT, W. E.; NELIS, H. J. (Ed.), Modern chromatographic analysis of vitamins. New York: Marcel Dekker.1992. 576 f.

PINHEIRO, E. R. Pectina da casca do maracujá amarelo (Passiflora edulis flavicarpa): otimização da extração com ácido cítrico e caracterização físico-química. $2007.79 \mathrm{f}$. Dissertação (Mestrado em Ciência dos Alimentos), Universidade Federal de Santa Catarina, Florianópolis - SC, 2007. 
POMMER, C. V.; MURAKAMI, K. R. N.; WATLINGTON, F. Goiaba no mundo. O Agronômico, v. 58, p. 22-26, 2006.

POURNAGHI-AZAR, M. H.; OJANI, R. A selective catalytica voltammetric determination of vitamin $\mathrm{C}$ in pharmaceutical preparations and complex matrices of fresh fruit juices. Talanta, v. 44, p. 297-303, 1997.

QUEIROZ, S. C. N.; JARDIM, I. C. S. F. Eletroforese capilar. Chemkeys. 2001. Disponível em: <http://chemkeys.com/br/2001/08/18/eletroforese-capilar/>. Acesso em: 10 de fev. 2012. RAMÍREZ, S. C.; CARRETERO, S. A.; BLANCO, C. C.; DE CASTRO, M. H. B.; GUTIÉRREZ, A. F. Analysis of carbohydrates in beverages by capillary electrophoresis with precolumn derivatization and UV detection. Food Chemistry, v. 87, p. 471-476, 2004.

RIBEIRO, E.P. \& SERAVALLI, E. A. G. Química de alimentos. São Paulo: Edgard Blucher, 2004. p. 155-157.

RIBÉREAU-GAYON, P.; GLORIES, Y.; MAUJEAN, A.; DUBOURDIEU, D. Phenolic compounds. In: HANDBOOK of enology: the chemistry of wine stabilization and treatments. Chichester: John Wiley, 2006. v. 2, p. 141-203.

ROCHA, T. L.; EVARISTO, R. G. S.; SILVA, L. P.; SOUZA, D. S. L.; MARRA, B. M.; COSTA, P. H.; MAGALHÃES, J. C. C.; MATTAR, M. C. S.; GROSSI-DE-SÁ, M. F. Metabolômica: aplicações e perspectivas. Brasília: Embrapa Recursos Genéticos e Biotecnologia, 2006. p. 1-38. (Embrapa Recursos Genéticos e Biotecnologia. Documentos, 189).

RODRIGUEZ-AMAYA D. B. Nature and distribution of carotenoids in foods. In: CHARALAMBOUS, G. (Ed.). Shelf-life studies of foods and beverages: chemical, biological, physical and nutritional aspects. Amsterdam: Elsevier Science, 1993. p. 547-589.

RODRIGUEZ-AMAYA, D. B. A guide to carotenóide analysis in foods. Washington: ILSI Press, 2001. $64 \mathrm{f}$.

RODRIGUEZ-AMAYA, D. B. Assessment of the provitamin A contents of foods: the Brazilian experience. Journal of Food Composition and Analysis, v. 9, p. 196-230, 1996.

RODRIGUEZ-AMAYA, D. B. Carotenoides y preparacion de alimentos: La retencion de los carotenóides provitamina A em alimentos preparados, procesados y almacenados. OMNI, p. 1-105, 1997. 
RODRIGUEZ-AMAYA, D. B.; RODRIGUEZ, E. B.; AMAYA-FARFAN, J. Advances in food carotenoid research: chemical and technological aspects, implications in human health. Malaysian Journal of Nutrition, v. 12, n. 1, p. 101-121, 2006.

ROE, J. H.; OESTERLING, M. J. The determination of fehydroascorbic acid and ascorbic acid in plant tissue by the 2, 4-dinitrophenylhydrazine method. LebensmittelWissenschaft und -Technologie, v. 5, p. 511- 517, 1972.

ROSA, J. S.; GODOY, R. L. O.; NETO, J. O.; CAMPOS, R. S.; MATTA, V. M.; FREIRE, C. A.; SILVA, A. S.; SOUZA, R. S. Desenvolvimento de um método de análise de vitamina C em alimentos por cromatografia líquida de alta eficiência e exclusão iônica. Ciência e Técnologia de Alimento, v. 27, n. 4, p. 837-846, 2007.

ROVIO, S.; SIMOLIN, H.; KOLJONEN, K.; SIRÉN, H. Determination of monossacharide composition in plant fiber materials by capillary zone electrophoresis. Journal of Chromatography A, v. 1185, p. 139-144, 2008.

ROVIO, S.; YLI-KAUHALUOMA, J.; SIRÉN, H. Determination of neutral carbohydrates by CZE with direct UV detection. Electrophoresis, v. 28, p. 3129-3135, 2007.

SANTOS, M. S.; PETKOWICZ, C. L. O.; HAMINIUK, C. W. I.; CÂNDIDO, L. M. B. Polissacarídeos extraídos da gabiroba (Campomanesia xanthocarpa Berg): Propriedades químicas e perfil reológico. Polímeros, v. 20, p. 352-358, 2010.

SCHIEWE, J.; MRESTANI, Y.; NEUBERT, R. Application and optimization of capillary zone electrophoresis in vitamin analysis. Journal of Chromatography A, v. 717, p. 255-259, 1995.

SCHWEIGGERT, R. M.; STEINGASS, C. B.; HELLER, A.; ESQUIVEL, P.; CARLE, R. Characterization of chromoplasts and carotenoids of red- and yellow-fleshed papaya (Carica papaya L.). Planta, v. 234, p. 1031-1044, 2011.

SEGATO, M. P.; SILVA, C. R.; JARDIM, I. C. S. F. Eletrocromatografia capilar: contextualização, estado da arte e perspectivas. Química Nova, v. 32, n. 2, p. 431-440, 2009. 
SENTANIN, M. A.; RODRIGUEZ-AMAYA, D. B. Teores de carotenóides em mamão e pêssego determinados por cromatografia líquida de alta eficiência. Ciência e Tecnologia de Alimentos, v. 27, n. 1, p. 13-19, 2007.

SÉRINO, S.; GOMEZ, L.; COSTAGLIOLA, G.; GAUTIER, H.; HPLC Assay of Tomato Carotenoids: Validation of a Rapid Microextraction Technique. Journal of Agricultural and Food Chemistry, v.57, p.8753-8760, 2009.

SERRANO, L. A. L. MARINHO, C. S.; LIMA, I. M.; MARTINS, M. V. V.; ROCHI, C. P.; TARDIN, F. D. Fenologia da goiabeira 'Paluma' sob diferentes sistemas de cultivos, épocas e intensidades de poda de frutificação. Bragantia, Campinas, v. 67, n. 3, p. 701-712, 2008.

SETIAWAN, B.; SULAEMAN, A.; GIRAUD, D. W.; DRISKELL, J. A. Carotenoid content of selected Indonesian fruits. Journal of Food Composition and Analysis, v. 14, p. 169-176, 2001 .

SILVA, A. S.; SOUZA, R. S. Desenvolvimento de um método de análise de vitamina C em alimentos por cromatografia líquida de alta eficiência e exclusão iônica. Ciência e Tecnologia de Alimentos, v. 27, n. 4, p. 837-836, 2007.

SILVA, E. C.; MACIEL, G. M.; ALVARENGA, P. P. M.; PAULA, A. C. C. F. F. Teores de $\beta$-caroteno e licopeno em função das doses de fósforo e potássio em frutos de diferentes genótico de tomateiro industrial. Bioscience Journal, v. 27, n. 2, p. 247-252, 2011.

SILVA, J. A. F.; COLTRO, W. K. T.; CARRILHO, E.; TAVARES, M. F. M. Tecnologia para as técnicas analíticas de eletromigração em capilares. Quimica Nova, v. 30, n. 3, p. 740$744,2007$.

SILVA, P. T.; LOPES, M. L. M.; MESQUITA, V. L. V. Efeito de diferentes processamentos sobre o teor de ácido ascórbico em suco de laranja utilizado na elaboração de bolo, pudim e geléia. Revista Ciência e Tecnologia de Alimentos, v. 26, n. 3, p. 678-682, 2006.

SILVA, R. N.; MONTEIRO, V. N.; ALCANFOR, J. D’A. X. Comparação de métodos para a determinação de açúcares redutores e totais em mel. Ciência e Tecnologia de Alimentos, v. 23, n. 3, p. 337-341, 2003. 
SINUCO, D. C.; STEINHAUS, M.; SCHIEBERLE, P.; OSORIO, C. Changes in odour-active compounds of two varieties of Colombian guava (Psidium guajava L.) during ripening. European Food Research and Technology, v. 230, p. 859-864, 2010.

SIQUEIRA, A. M. DE A. Resfriamento rápido por ar forçado de goiaba cv. Paluma: avaliação dos parâmetros físicos, físico-químicos, sensoriais e do processo. 2009. 133f. Dissertação (Mestrado) - Ciências Agrárias. Departamento de Tecnologia de Alimentos, Universidade Federal do Ceará, Fortaleza, 2009.

SKOOG, D. A. Princípios de análise instrumental. São Paulo: Bookman, p. 445-474, 641676, 2002.

SMIRNOFF N.; WHEELER, G. L. Ascorbic acid in plants: biosynthesis and function. Cristical Reviews in Plant Sciences, v 19, n. 4, p. 267-290, 2000.

SOGA, T.; SERWE, M. Determination of carbohydrates in food samples by capillary electrophoresis with indirect UV detection. Food Chemistry, v. 69, p. 339-344, 2000.

SOUZA, S. L.; MOREIRA, A. P. B.; PINHEIRO-SANT'ANA, H. M.; ALENCAR, E. R. Conteúdo de carotenos e provitamina A em frutas comercializadas em Viçosa, Estado de Minas Gerais. Acta Scientiarum Agronomy, v. 26, p. 453-459, 2004.

TANG, Y.; WU, M. A quick method for the simultaneous determination of ascorbic acid and sorbic acid in fruits juices by capillary zone electrophoresis. Talanta, v. 65, p. 794-798, 2005.

TAVARES, M. F. M. Eletroforese capilar: conceitos básicos. Química Nova, v. 19, n. 2, p. $173-181,1996$.

TAVARES, M. F. M. Mecanismos de separação em eletroforese capilar. Química Nova, v. 5, n. 5, p. 493-511, 1997.

TEIXEIRA, J.; PETRARCA, M. H.; TADIOTTI, A. C.; SYLOS, C. M. Degradação do ácido ascórbico em goiabada industrializada submetida a diferentes condições de estocagem. Alimentos e Nutrição, v. 17, n. 3, p. 281-286, 2006.

THAKUR, B.R.; SINGH, R.K.; HANDA, A.V. Chemistry and uses of pectin - a review. Critical Reviews in Food Science and Nutrition, v. 37, n. 1, p. 47-73, 1997.

THOMPSON, C. O.; TRENERRY, V. C. A rapid method for the determination of total L- 
ascorbic acid in fruits and vegetables by micellar electrokinetic capillary chromatography. Food Chemistry, v. 53, p. 43-50, 1995.

VAYABOURY, W.; KIRBY, D.; GIANI, O.; COTTET, H. Noncovalent coatings for the separation of synthetic polypeptides by nonaqueous capillary electrophoresis. Electrophoresis, v. 26, p. 2187-2197, 2005.

VERSARI, A.; MATTIOLI, A.; PARPINELLO, G. P.; GALASSI, S. Rapid analysis of ascorbic and isoascorbic acids in fruit juice by capillary electrophoresis. Food Control, v. 15, p. 355-358, 2004.

VILLAS-BÔAS, S. G.; MAS, S.; AKESSON, M.; SMEDSGAARD, J.; NIELSEN, J. Mass spectrometry in metabolome analysis. Mass Spectrometry Reviews, v. 24, p. 613- 646, 2005.

VIRK, B.S.; SOGI, D.S. Extraction and characterization of pectin from apple pomace (Malus Pumila Cv Amri) peel waste. International Journal of Food Properties, v. 7, n. 03, p. 1-11, 2004.

WATADA, A. E.; HERNER, R. C.; KADER, A. A.; ROMANI, R. J.; STABY, G. L. Terminology for the description of developmental stages of horticultural crops. HortScience, v. 19, n. 1, p. 20-21, 1984.

WATANABE, H. S. Comercialização da goiaba no mercado nacional. In: NATALE, W.; ROZANE, D. E.; SOUZA, H. A.; AMORIM, D. A. (Ed.). Cultura da goiaba do plantio à comercialização. Jaboticabal: Santa Terezinha, 2009. v.1, p.133-150.

WATANABE, T.; HASEGAWA, N.; YAMAMOTO, A.; NAGAI, S.; TERABE, S. Separation and determination of yellow and red safflower pigments in food by capillary electrophoresis. Bioscience, Biotechnology, and Biochemistry, v. 61, n. 7, p. 1179-1183, 1997.

WILBERG, V. C.; RODRIGUEZ-AMAYA, D. B. HPLC quantitation of major carotenoids of fresh and processed guava, mango and papaya. Lebensmittel-Wissenschaft undTechnologie, v. 28, p. 474-480, 1995.

WILlATS, W. G. T.; KNOX, J. P.; MIKKELSEN, J. D. Pectin: new insights into an old polymer are starting to gel. Trends in Food Science \& Technology, v. 17, p. 97-104, 2006. 
WILLS, R. B. H.; WIMALASIRI, P.; GREENFIELD, H. Dehydroascorbic acid levels in fresh fruit and vegetables in relation to total vitamin $\mathrm{C}$ activity. Journal of Agricultural and Food Chemistry, v. 32, p. 836-838, 1984.

WILSON, C. W.; SHAW, P. E.; CAMPBELL, C. W. Determination of organic acids and sugars in guava (Psidium guajava L.) cultivars by high-performance liquid chromatography. Journal of the Science of Food and Agriculture, v. 33, p. 777-780, 1982.

WIMALASIRI, P.; WILLS, R. B. H. Simultaneous analysis of ascorbic acid and dehydroascorbic acid in fruit and vegetables by high-performance liquid chromatography. Journal of Chromatography, v. 256, p. 368-371, 1983.

WU, X.; DIAO, Y.; SUN, C.; YANG, J.; WANG, Y.; SUN, S. Fluorimetric determination of ascorbic acid with o-phenylenediamine. Talanta, v. 59, p. 95-99, 2003.

XIA, L.; SUN, Z. W.; LI, G. L.; SUO, Y. R. YOU, J. M. A sensitive analytical method for the component monosaccharides of the polysaccharides from a Tibetan herb potentilla anserine L. by capillary zone electrophoresis with UV detector. Eur Food Research Technology, v. 230, p. $715-722,2010$ a.

XIA, Y.; LIANG, J.; YANG, B.; WANG, Q.; KUANG, H. A new method for quantitative determination of two uronic acids by CZE with direct UV detection. Biomedical Chromatography, v. 25, p. 1030-1037, 2011.

XIA, Y.; WANG, Q.; LIANG, J.; YANG, B.; LI, G.; KUANG, H. Development and application of a rapid and efficient CZE method couplet with correction factors for determination of monosaccharide composition of acidic hetero-polysaccharides from Ephedra Sinica. Phytochemical Analysis, v. 22, p. 103-111, $2010 \mathrm{~b}$.

YAHIA, E. M.; PADILHA, M. C.; AGUILAR, G. G. Ascorbic acid content in relation to ascorbic acidoxidase activity and polyamine content in tomato and Bell Pepper fruits during development, maturation and senescence. Lebensmittel-Wissenschaft und Technology, v. 34, p. 452-457, 2001.

ZERDIN, K.; ROONEY, M. L.; VERMUE, J. The vitamin C content of orange juice packed in an oxygen scavenger material. Food Chemistry, v. 82, p. 387-395, 2003. 